\title{
Discovery and Characterization of the Potent and Highly Selective 1,7-Naphthyridine-Based Inhibitors BAY-091 and BAY-297 of the Kinase PIP4K2A
}

Lars Wortmann, Nico Bräuer, Simon J. Holton, Horst Irlbacher, Jörg Weiske, Christian Lechner, Robin Meier, Jakob Karén, Catrine Berthold Siöberg, Vera Pütter, Clara D. Christ, Antonius ter Laak, Philip Lienau, Ralf Lesche, Barbara Nicke, Shing-Hu Cheung, Marcus Bauser, Andrea Haegebarth, Franz von Nussbaum, Dominik Mumberg, and Clara Lemos*

Cite This: J. Med. Chem. 2021, 64, 15883-15911

Read Online

ACCESS | Lill Metrics \& More | 回 Article Recommendations ｜ sl Supporting Information

ABSTRACT: PIP4K2A is an insufficiently studied type II lipid kinase that catalyzes the conversion of phosphatidylinositol-5phosphate (PISP) into phosphatidylinositol 4,5-bisphosphate $\left(\mathrm{PI} 4,5 \mathrm{P}_{2}\right)$. The involvement of $\mathrm{PIP} 4 \mathrm{~K} 2 \mathrm{~A} / \mathrm{B}$ in cancer has been suggested, particularly in the context of p53 mutant/null tumors. PIP4K2A/B depletion has been shown to induce tumor growth inhibition, possibly due to hyperactivation of $\mathrm{AKT}$ and reactive oxygen species-mediated apoptosis. Herein, we report the identification of the novel potent and highly selective inhibitors BAY-091 and BAY-297 of the kinase PIP4K2A by high-throughput screening and subsequent structure-based optimization. Cellular target engagement of BAY-091 and BAY-297 was demonstrated using cellular thermal shift assay technology. However, inhibition of PIP4K2A with

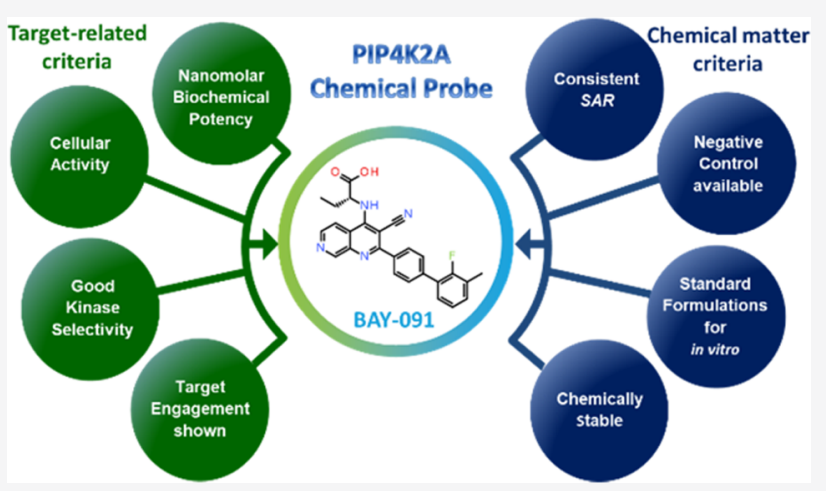
BAY-091 or BAY-297 did not translate into the hypothesized mode of action and antiproliferative activity in p53-deficient tumor cells. Therefore, BAY-091 and BAY-297 serve as valuable chemical probes to study PIP4K2A signaling and its involvement in pathophysiological conditions such as cancer.

\section{INTRODUCTION}

The phosphatidylinositol-5-phosphate 4-kinases (PIP4Ks) are type II lipid kinases that catalyze the conversion of phosphatidylinositol-5-phosphate (PI5P) into phosphatidylinositol 4,5-bisphosphate (PI4,5P $\mathrm{P}_{2}$ ). Three different isoforms have been described (PIP4K2A, PIP4K2B, and PIP4K2C), which show different subcellular localization and enzyme activity. The PIP4K2A isoform is the most active of the three, being 100-500-fold more active than PIP4K2B and about 1000-fold more active than PIP4K2C. As for their subcellular localization, PIP4K2A is predominantly localized in the cytoplasm and plasma membrane, while PIP4K2B can be additionally present in the nucleus. PIP4K2C seems to localize in a not well-defined endomembrane compartment. ${ }^{1}$

In recent years, the therapeutic potential of PIP4K2A/B inhibition in cancer has been studied, particularly in the context of p53 mutant/null tumors. A groundbreaking study published in 2013 demonstrated that the depletion of PIP4K2A/B resulted in the inhibition of tumor growth, both in vitro and in vivo, selectively in p53-deficient tumors. ${ }^{2}$ These effects were accompanied by an increased AKT phosphorylation, along with a significant increase in oxygen con- sumption and reactive oxygen species (ROS), and reduced glucose metabolism. The authors hypothesized that the metabolic imbalance and high ROS levels were likely to contribute to the observed senescence phenotype. Consistently, addition of the antioxidant $\mathrm{N}$-acetylcysteine to the cell culture media partially rescued cell growth, thereby suggesting that under conditions of oxidative stress (e.g., p53-deficient tumors), PIP4K2A/B are essential for cell survival, rendering them as a promising target for cancers lacking p53.,

Subsequently, Jude and co-workers showed that knockdown of PIP4K2A alone in THP-1 cells (p53 mut) resulted in the inhibition of proliferation and colony formation in vitro and prevented AML development in xenografts. ${ }^{4}$ Furthermore, PIP4K2A knockdown led to apoptosis and G1 cell cycle arrest,

Received: July 13, 2021

Published: October 26, 2021 
Table 1. SAR of Substituents at the 4-Position of the Naphthyridine Core ${ }^{a}$

\begin{tabular}{|c|c|c|c|c|c|c|}
\hline Compd & $\mathrm{R}^{1}$ & $\mathrm{R}^{2}$ & $\begin{array}{l}\text { PIP4K2A ADP-Glo, } \\
10 \mu \mathrm{M} \text { ATP } \\
\text { (LLE)/HTRF, } 10 \mu \mathrm{M} \\
\text { ATP, IC }{ }_{50}[\mu \mathrm{M}]\end{array}$ & $\begin{array}{c}\text { PIP4K2A ADP-Glo, } \\
250 \mu \mathrm{M} \text { ATP/HTRF, } \\
2 \mathrm{mM} \text { ATP//p-AKT } \\
\text { HTRF THP-1, IC }{ }_{50} \\
{[\mu \mathrm{M}]}\end{array}$ & $\log \mathrm{D} / \mathrm{TPSA}$ & $\begin{array}{c}\text { Caco-2 } \\
P_{\text {app A-B }} \\
{[\mathrm{nm} / \mathrm{s}] / \mathrm{ER}^{b}}\end{array}$ \\
\hline $\begin{array}{c}1 \\
(r a c)\end{array}$ & & & $0.014(5.61) / \mathrm{nd}$ & $0.051 / \mathrm{nd} / \mathrm{nd}$ & $2.1 / 108$ & $0 /-$ \\
\hline 2 & & & $0.005(6.02) / 0.027$ & $0.059 / 0.18 / />50$ & $2.1 / 108$ & $0 /-$ \\
\hline 10 & & $\mathrm{Br}$ & $0.066(5.46) / \mathrm{nd}$ & $2.45 / \mathrm{nd} / />50$ & $1.6 / 99$ & $0 /-$ \\
\hline 11 & & $\mathrm{Br}$ & $>20 /$ nd & nd & $2.3 / 105$ & nd \\
\hline 12 & & $\mathrm{Br}$ & $0.61(3.75) / 3.19$ & nd & $2.2 / 105$ & $202 / 0.9$ \\
\hline $\begin{array}{c}13 \\
(r a c)\end{array}$ & & $\mathrm{Br}$ & $3.00(3.2) / \mathrm{nd}$ & nd & $2.1 / 105$ & nd \\
\hline 14 & & $\mathrm{Br}$ & $7.45(2.94) / \mathrm{nd}$ & nd & $1.9 / 105$ & $148 / 1.9$ \\
\hline 15 & & $\mathrm{Br}$ & $>20 /$ nd & nd & $2.1 / 96$ & $206 / 1.2$ \\
\hline 16 & & $\mathrm{Br}$ & $>20 /$ nd & nd & $2.1 / 105$ & nd \\
\hline 17 & & & $0.089(4.03) / 0.45$ & $0.38 / 11.2 / / \mathrm{nd}$ & $3.0 / 114$ & $151 / 0.5$ \\
\hline $\begin{array}{c}18 \\
(r a c)\end{array}$ & & & $0.65(2.71) / \mathrm{nd}$ & $7.91 / \mathrm{nd} / / \mathrm{nd}$ & $3.6 / 114$ & nd \\
\hline $\begin{array}{c}19 \\
(r a c)\end{array}$ & & & $0.82(3.07) / \mathrm{nd}$ & $9.29 / \mathrm{nd} / />50$ & $3.0 / 114$ & nd \\
\hline 20 & & & $0.65(2.65) / \mathrm{nd}$ & $5.47 / \mathrm{nd} / / \mathrm{nd}$ & $3.4 / 114$ & nd \\
\hline $\begin{array}{c}21 \\
(r a c)\end{array}$ & & & $0.74(3.17) / \mathrm{nd}$ & $2.74 / \mathrm{nd} / / \mathrm{nd}$ & $2.8 / 123$ & nd \\
\hline 22 & & & $0.49(2.75) / \mathrm{nd}$ & $14.1 / \mathrm{nd} / />50$ & $3.6 / 100$ & nd \\
\hline 23 & & & $0.30(3.09) / \mathrm{nd}$ & $14.3 / \mathrm{nd} / />50$ & $3.7 / 91$ & nd \\
\hline
\end{tabular}


Table 1. continued

\begin{tabular}{|c|c|c|c|c|c|c|}
\hline Compd & $\mathrm{R}^{1}$ & $\mathrm{R}^{2}$ & $\begin{array}{l}\text { PIP4K2A ADP-Glo, } \\
10 \mu \mathrm{M} \text { ATP } \\
\text { (LLE)/HTRF, } 10 \mu \mathrm{M} \\
\text { ATP, IC } \text { IC }_{50}[\mu \mathrm{M}]\end{array}$ & $\begin{array}{c}\text { PIP4K2A ADP-Glo, } \\
250 \mu \mathrm{M} \text { ATP/HTRF, } \\
2 \mathrm{mM} \text { ATP//p-AKT } \\
\text { HTRF THP- } 1, \mathrm{IC}_{50} \\
{[\mu \mathrm{M}]}\end{array}$ & $\log \mathrm{D} / \mathrm{TPSA}$ & $\begin{array}{c}\text { Caco-2 } \\
P \text { app A-B } \\
{[\mathrm{nm} / \mathrm{s}] / \mathrm{ER}^{b}}\end{array}$ \\
\hline 24 & & & $0.04(4.79) / 0.26$ & $0.15 / 2.33 / />50$ & $2.2 / 134$ & $0 /-$ \\
\hline 25 & & & $0.03(4.75) / 0.37$ & $0.15 / 3.36 / />50$ & $2.3 / 134$ & $0 /-$ \\
\hline 26 & & & $0.56(3.38) / 1.67$ & $12.6 />20 / />50$ & $2.7 / 100$ & nd \\
\hline $\begin{array}{c}27 \\
(\mathrm{rac})\end{array}$ & & & $0.91(2.35) / 6.98$ & $>20 />20 / />50$ & $3.6 / 117$ & nd \\
\hline 28 & & & $0.20(4.29) / 1.27$ & $2.60 / 13.4 / />50$ & $2.2 / 96$ & $43 / 6.6$ \\
\hline 29 & & & $3.24(2.51) />20$ & $>20 />20 / />50$ & $3.0 / 102$ & nd \\
\hline 30 & & & $0.63(2.76) / \mathrm{nd}$ & $6.90 / \mathrm{nd} / />50$ & $3.0 / 85$ & nd \\
\hline 31 & & & $10.2(0.93) / \mathrm{nd}$ & $\mathrm{nd} / \mathrm{nd} / />50$ & $3.8 / 59$ & nd \\
\hline
\end{tabular}

${ }^{a} \mathrm{IC}_{50}$ values are arithmetic means of multiple measurements. nd $=$ not determined. ${ }^{b} \mathrm{ER}=$ efflux ratio.

which is associated with AKT phosphorylation and mTOR pathway activation.

The link between PIP4K2A/B depletion and AKT phosphorylation is well established. ${ }^{3-6}$ Considering the welldescribed oncogenic role of AKT, it seems paradoxical that inhibition of PIP4K2A/B and consequent AKT activation could somehow result in tumor growth arrest. Interestingly, Nogueira and co-workers showed that AKT activation leads to an increase in intracellular ROS through increased oxygen consumption and inhibition of the expression of ROS scavengers downstream of FoxO. ${ }^{7}$ Therefore, in the context of oxidative stress, AKT hyperactivation sensitizes tumor cells to ROS-mediated senescence/apoptosis. ${ }^{7,8}$

Overall, the current literature strongly suggests a synthetic lethality relationship between PIP4K2A/B and p53 deficiency. Essentially, in p53-deficient cells, which have increased redox levels, maintaining the activity of PIP $4 \mathrm{~K} 2 \mathrm{~A} / \mathrm{B}$ is critical to prevent overactivation of $\mathrm{AKT}$ and a further increase in the ROS levels. Therefore, inhibition of PIP4K2A/B is expected to induce ROS-dependent senescence/apoptosis selectively in p53-deficient tumor cells. ${ }^{1,9}$

Despite the promising therapeutic potential of inhibiting PIP4K2A/B in cancer, there is a clear lack of selective inhibitors of these kinases. Recently, the discovery of THZP1-2, which is described as a covalent inhibitor of all three PIP4K2 isoforms, was reported. ${ }^{10}$ Given the very benign phenotype of PIP4K $2 \mathrm{~A}^{-/-}$mice $^{2}$ compared to that of $\mathrm{PIP} 4 \mathrm{~K}_{2} \mathrm{~B}^{-/-}$mice, which show enhanced insulin sensitivity and reduced adiposity, ${ }^{11}$ together with the fact that inhibition of PIP4K2A alone is sufficient to inhibit tumor growth, ${ }^{4}$ we aimed to develop the first potent and selective PIP4K2A inhibitors for the treatment of p53-deficient tumors.

\section{RESULTS AND DISCUSSION}

Profiling of High-Throughput Screening Hit 1 and Initial Lead 2. For the identification of a small-molecule inhibitor of PIP4K2A, we screened the Bayer AG compound library (approximately 3.9 million compounds) using a highthroughput luminescence-based kinase inhibition assay: ${ }^{12-14}$ PIP4K2A was incubated with the test compounds, PI5P substrate, and $10 \mu \mathrm{M}$ ATP for $60 \mathrm{~min}$. The amount of ADP generated during the phosphorylation reaction was quantified using a commercially available reagent kit (ADP-Glo, Promega). Following hit confirmation in the primary assay and a check for assay system interference, 3803 compounds were selected for the hit list. A subsequent hit-to-lead process included the removal of pan-assay interference compounds ${ }^{15}$ and resulted in the identification of cyanonaphthyridine singleton 1 (see Table 1) with an $\mathrm{IC}_{50}$ value of $14 \mathrm{nM}$ as a promising lead structure, which was selected as a starting point for further optimization.

We were able to confirm the on-target binding of compound 1 to the PIP4K2A protein via a thermal shift assay (TSA) experiment $^{16}$ (Figure 1). The resulting $10.3 \mathrm{~K}$ temperature shift with $100 \mu \mathrm{M}$ compound 1 indicated a strong stabilization of PIP4K2A upon compound 1 target binding. 


\section{PIP4K2A}

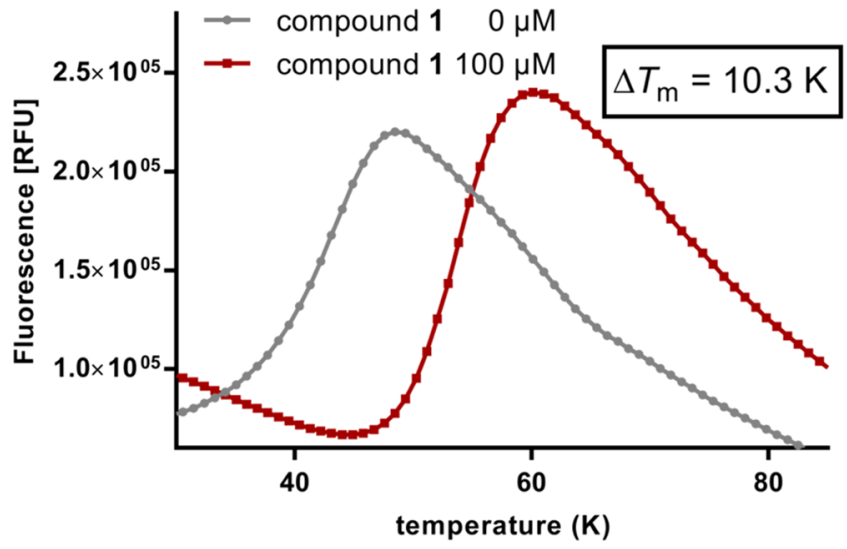

Figure 1. Thermal shift assay experiment with compound 1 and PIP4K2A.

The cocrystal structure of compound $\mathbf{1}$ in complex with PIP4K2A (PDB 6YM3) revealed the binding mode within the ATP binding site. The binding of $\mathbf{1}$ is associated with inducedfit changes to the Phe ${ }^{134}$ and Lys ${ }^{145}$ side chains that result in a good steric and electrostatic fit within the binding site (Figure 2A). Key interactions (Figure 2B) between PIP4K2A and 1 include a hydrogen bond between the naphthyridine nitrogen at position 7 and the backbone nitrogen of $\mathrm{Val}^{199}$ that is part of the kinase hinge motif and a $\pi-\pi \mathrm{T}$-stacking electronic interaction between the terminal naphthyridine ring system and the adjacent $\mathrm{Phe}^{200}$ side chain. The $(R)$-configuration of $\mathbf{1}$ provides an optimal exit vector for the carboxylic acid group that allows hydrogen-bonding and salt-bridge interactions with $\mathrm{Thr}^{232}$ and Lys ${ }^{209}$. The methyl group at this stereocenter points towards the solvent channel, suggesting that larger substituents could also be accommodated at this position. The ethoxybiphenyl motif extends into a hydrophobic subpocket (Figure 2C) adjacent to the hinge region of the ATP binding site. The results obtained from this cocrystal structure of 1 with PIP4K2A guided our further structure optimization and helped us to interpret the structure-activity relationships (SAR).

With this information for high-throughput screening (HTS) hit $\mathbf{1}$ in hand, we synthesized the closely related ethyl analogue 2 , as outlined in Scheme 1. Commercially available carboxylic acid 3 was converted into the corresponding active ester $\mathbf{5}$, which was subsequently reacted with cyanoacetophenone 6 and sodium hydride to furnish the cyanonaphthyridine core 7 . Alcohol 7 was converted into the corresponding chloride 8a via reaction with phosphoryl chloride. Due to the high reactivity and resulting low stability of intermediate $\mathbf{8 a}$, we switched to the more stable bromide $\mathbf{8 b}$ later in the project. The reaction of $\mathbf{8 a}$ or $\mathbf{8 b}$ with amine nucleophiles such as tertbutyl (R)-2-aminobutanoate gave rise to intermediate 9 . Subsequent cleavage of the tert-butyl ester under acidic conditions followed by a Suzuki reaction using (2-ethoxyphenyl) boronic acid furnished compound $\mathbf{2}$ in a low overall yield.

Compound 2 was profiled in pharmacological, physicochemical, and DMPK assays in vitro (Figure 3). Its $\mathrm{IC}_{50}$ value of 5.5 $\mathrm{nM}$ in the biochemical PIP4K2A ADP-Glo assay containing 10 $\mu \mathrm{M}$ ATP (low ATP) translated to an $\mathrm{IC}_{50}$ value of $59 \mathrm{nM}$ in the assay containing $250 \mu \mathrm{M}$ ATP (medium ATP). As the typical ATP concentration in cells is in the millimolar range,
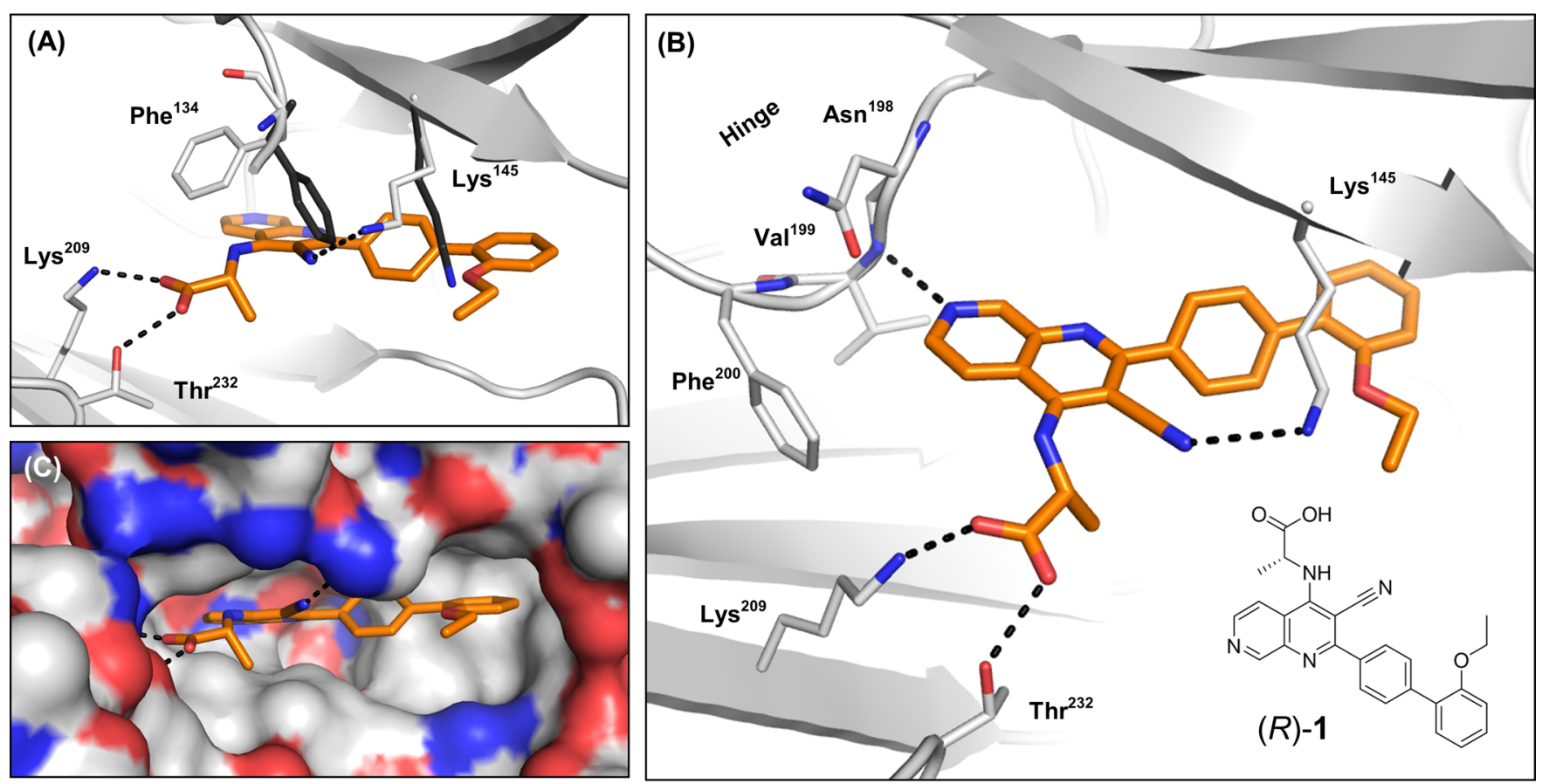

Figure 2. X-ray analysis of compound 1. (A) Overlay of the PIP4K2A-compound 1 complex structure (protein C, N, and O atoms are colored gray, blue, and red, respectively. Compound $1 \mathrm{C}, \mathrm{N}$, and $\mathrm{O}$ atoms are colored orange, blue, and red, respectively) with selected residues from the PIP4K2A apo structure (PDB 2YBX) (C, N, and O atoms colored dark gray, blue, and red, respectively). (B) Cartoon representation of PIP4K2A (gray) with key interacting side chains in stick representation with $\mathrm{C}, \mathrm{N}$, and $\mathrm{O}$ atoms colored gray, blue, and red, respectively. Compound $\mathbf{1}$ is also shown in stick representation with $\mathrm{C}, \mathrm{N}$, and $\mathrm{O}$ atoms colored orange, blue, and red, respectively. Key interactions between $\mathbf{1}$ and the protein are shown as black dotted lines. (C) PIP4K2A surface representation, colored as in (B). 
Scheme 1. Synthesis of Initial Lead Compound $2^{a}$<smiles>[X]c1c(C#N)c(-c2ccc(Br)cc2)nc2cnccc12</smiles>
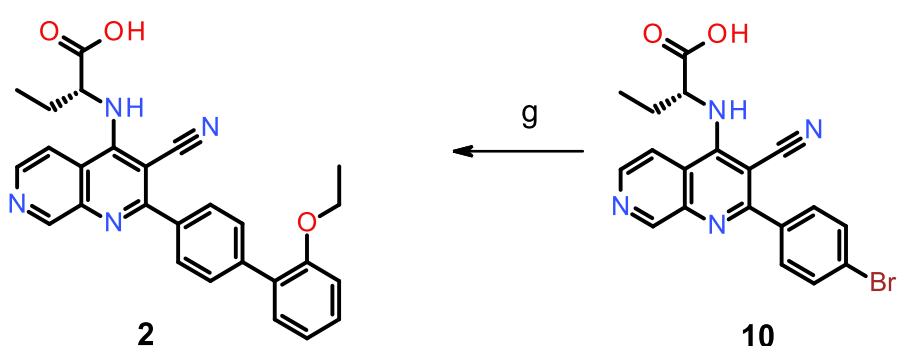

10

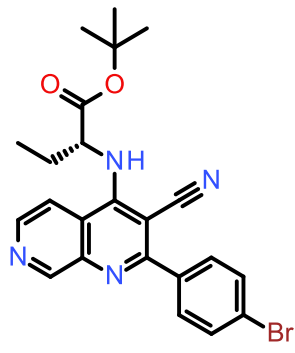

9

${ }^{a}$ Reagents and conditions: (a) 1-ethyl-3-(3-dimethylaminopropyl)carbodiimide $\cdot \mathrm{HCl}$, DIPEA, THF, quantitative; (b) $\mathrm{NaH}, \mathrm{THF}, 85 \%$; (c) POCl 3 , 21\%; (d) $\mathrm{POBr}_{3}, \mathrm{DMF}, 50 \%$; (e) (R)-2-Aminobutanoate hydrochloride, $\mathrm{Et}_{3} \mathrm{~N}, \mathrm{DMF}, 89 \%$; (f) $\mathrm{HCl}, 1,4-$ dioxane, 57\%; and (g) (2ethoxyphenyl)boronic acid, $\mathrm{Pd}\left(\mathrm{PPh}_{3}\right)_{4}, \mathrm{~K}_{2} \mathrm{CO}_{3}, \mathrm{DMF}, \mathrm{H}_{2} \mathrm{O}, 15 \%$.

\begin{tabular}{|c|c|c|c|c|c|}
\hline \multicolumn{4}{|c|}{ Pharmacological in vitro Properties } & \multicolumn{2}{|c|}{ Physicochemical Properties } \\
\hline \multicolumn{2}{|c|}{ PIP4K2A ADP Glo $20 \mu \mathrm{M}$ ATP IC $C_{50}$} & \multicolumn{2}{|c|}{$5.5 \mathrm{nM}$} & $\mathrm{MW}$ [g*mol] & 452 \\
\hline \multicolumn{2}{|c|}{ PIP4K2A ADP Glo $250 \mu \mathrm{M}$ ATP IC 50} & \multicolumn{2}{|c|}{$59 \mathrm{nM}$} & $\operatorname{TPSA}\left[\AA^{2}\right]$ & 108 \\
\hline \multicolumn{2}{|c|}{ PIP4K2A HTRF $10 \mu \mathrm{M}$ ATP IC } & \multicolumn{2}{|c|}{$27 \mathrm{nM}$} & LogD @pH 7.5 & 2.1 \\
\hline \multicolumn{2}{|c|}{ PIP4K2A HTRF 2 mM ATP IC 50} & \multicolumn{2}{|c|}{$182 \mathrm{nM}$} & Sw pH $6.5[\mu \mathrm{M}]$ & 247 \\
\hline \multicolumn{6}{|c|}{ In vitro DMPK Properties } \\
\hline \multirow{2}{*}{$\begin{array}{l}\text { Caco2 } \\
\text { permeability }\end{array}$} & \multicolumn{2}{|c|}{$P_{\text {app }}(A-B)[n m / s]$} & \multicolumn{2}{|c|}{$P_{\text {app }}(B-A)[n m / s]$} & efflux ratio \\
\hline & \multicolumn{2}{|c|}{0} & & 239 & - \\
\hline \multirow{3}{*}{$\begin{array}{l}\text { metabolic } \\
\text { stability }\end{array}$} & & & & $L[L / h / k g]$ & $\mathbf{F}_{\max }[\%]$ \\
\hline & \multicolumn{2}{|c|}{ liver microsomes $(r)$} & & 0.5 & 87 \\
\hline & \multicolumn{2}{|c|}{ hepatocytes (r) } & & 0.5 & 87 \\
\hline
\end{tabular}

Figure 3. In vitro pharmacological, DMPK and physicochemical properties of 2.

we aimed to establish a high ATP assay as well. Unspecific hydrolysis of ATP to ADP as a side reaction in the ADP-Glo assay prohibited the use of this assay with millimolar ATP concentrations. Therefore, we set up a second biochemical PIP4K2A assay, based on homogeneous time-resolved fluorescence (HTRF) technology, containing $10 \mu \mathrm{M}$ ATP (low ATP) or $2 \mathrm{mM}$ ATP (high ATP). There was a good correlation between all four assays during the course of our optimization program (see Figure 4). A comparison of the results of the low ATP IC $_{50}$ values for both assay formats typically revealed a $\sim 3$ to 5 times higher sensitivity of compound 2 in the PIP4K2A ADP-Glo assay.

Compound 2 revealed drug-like physicochemical properties $^{17}$ (Figure 3) with its $\log D$ value, topological polar surface area (TPSA), and water solubility in an optimal range. Compound $\mathbf{2}$ showed high metabolic stability in rat liver microsome and rat hepatocyte assays. However, in the Caco-2 permeability assay, $\mathbf{2}$ showed no permeation from the apical to basolateral direction $\left(P_{\text {app }} \mathrm{A}-\mathrm{B}=0 \mathrm{~nm} / \mathrm{s}\right)$. Therefore, compound optimization focused on the improvement of permeability in Caco- 2 cells (i.e., oral absorption) as well as on a further increase in biochemical PIP4K2A potency.

Structure-Activity Relationships. In our initial optimization efforts, we investigated the 4-position of the naphthyridine core with a focus on improving the permeability in the Caco-2 assay as well as biochemical potency of the compounds (Table 1). Besides compounds 1 and $\mathbf{2}$ bearing an $o$-ethoxyphenyl substituent as $R^{2}$, the corresponding bromo precursors were investigated (see compound 10), which were significantly less potent but considered suitable for the investigation of the SAR and ranking of the 4-substituents. To tackle the low Caco-2 permeability, the carboxylic acid 


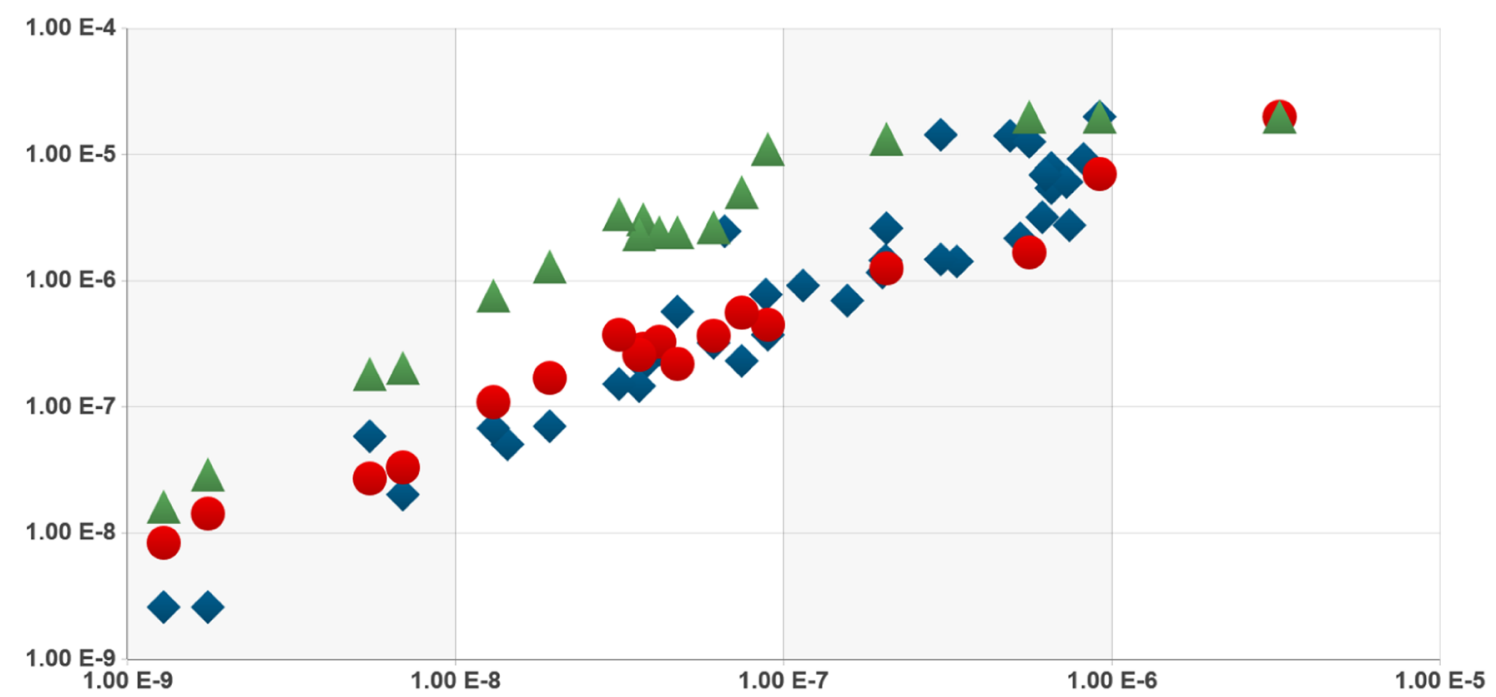

Figure 4. In vitro biochemical assay correlation for cyanonaphthyridine series. $X$-axis: PIP4K2A ADP-Glo, $10 \mu \mathrm{M}$ ATP, IC $\mathrm{C}_{50}[\mathrm{M}] ; \mathrm{Y}_{\text {-axis: }} \mathrm{PIP} 4 \mathrm{~K} 2 \mathrm{~A}$ ADP-Glo, $250 \mu \mathrm{M}$ ATP, $\mathrm{IC}_{50}[\mathrm{M}]$ (blue diamonds); PIP4K2A HTRF, $10 \mu \mathrm{M}$ ATP, IC I0 $[\mathrm{M}]$ (red circles); PIP4K2A HTRF, 2 mM ATP, IC 50 [M] (green triangles).

moiety in compound $\mathbf{1 0}$ was replaced by the corresponding carboxamide, which led to a potency reduction of one log unit for $(R)$-configured bromide 12, a trend seen for the entire lead series during optimization. (S)-Configured bromo analogue $\mathbf{1 1}$ proved inactive in the biochemical assay, a result that is in good alignment with the available cocrystal structure (cf. Figure 2B). Tests on a set of compounds with different $\alpha$ amino acid amide side chains (11-21) led to the identification of $(R)$-configured 2-aminobutyric acid and 2-aminobutyramide as being the optimum side chains with respect to PIP4K2A inhibitory activity. Secondary/tertiary carboxamides (22, 23) or lactam 26 resulted in a drop in PIP4K2A inhibitory activity, as did sulfonamide 27. As intended, carboxamides (e.g., 12/ 17) revealed good permeability in the Caco- 2 assay compared to their corresponding carboxylic acids (e.g., 10/2). NAcylsulfonamides as carboxylic acid bioisosteres, such as compounds 24 or $\mathbf{2 5}$, retained good PIP4K2A activity, but permeability in the Caco-2 assay was not improved. Removal of the carboxylic acid or amide side chain led to a significant drop in biochemical potency, as shown for naphthyridines $\mathbf{3 0}$ and 31 .

Besides the profiling of these compounds in the biochemical ATP consumption (ADP-Glo) assay at low ATP concentration $(10 \mu \mathrm{M})$, they were tested at $0.25 \mathrm{mM}$ ATP concentration as well as in the biochemical PIP4K2A HTRF binding competition assay (low ATP: $10 \mu \mathrm{M}$, high ATP: $2 \mathrm{mM}$ ). As expected for a competitive mechanism, the inhibitory activity dropped when changing from a low ATP to a medium/high ATP setting, the latter mimicking the actual conditions in a cell. For example, carboxamide 17 had $\mathrm{IC}_{50}$ values of 0.089 / $0.45 \mu \mathrm{M}$ (ADP-Glo, $10 \mu \mathrm{M}$ ATP/HTRF, $10 \mu \mathrm{M}$ ATP) at low ATP concentration and a reduced inhibitory activity, with $\mathrm{IC}_{50}$ values of $0.38 / 11.2 \mu \mathrm{M}$ (ADP-Glo, $0.25 \mathrm{mM}$ ATP/HTRF, 2 mM ATP), in the medium/high ATP setting. When comparing the biochemical potency of primary carboxamide 17 with the corresponding carboxylic acid 2, we again observed a potency increase of one log unit for the carboxylic acid.

To improve the permeation properties ${ }^{18}$ in Caco- 2 cells (i.e., oral absorption) for the carboxylic acids of this series, acidic compounds were designed with reduced TPSA, reduced number of hydrogen-bond donors, and reduced acidity (Figure
5). Replacing the 4-amino functionality in $\mathbf{1}$ by a methylene group is the simplest way of achieving all three goals. As a

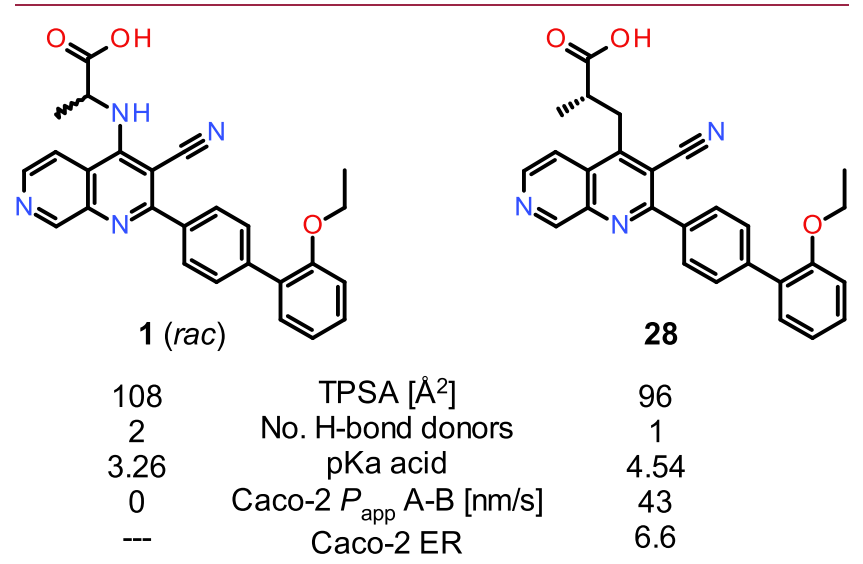

Figure 5. Improving permeation properties in the carboxylic acid series.

result, methylene analogue $\mathbf{2 8}$ displayed significantly improved properties in the Caco- 2 assay $\left[P_{\text {app }} \mathrm{A}-\mathrm{B}\right.$, efflux ratio (ER)], thereby providing a path forward for improved oral absorption of acidic compounds of this series. Unfortunately, this improvement was accompanied by a significant loss in PIP4K2A inhibitory potency. As expected, corresponding carboxamide 29 lead to a decrease in potency.

We then turned our attention to the peripheral phenyl ring substitution pattern for additional potency improvements within the carboxamide series. In general, small substituents were well tolerated at the ortho, meta, or para position of the peripheral phenyl ring (Table 2). Considering the ortho position, only fluorine derivative $\mathbf{3 2}$ along with methyl ether $\mathbf{3 5}$ revealed a twofold potency improvement over ethoxysubstituted analogue 17 , with $\mathrm{IC}_{50}$ values of 37 and $42 \mathrm{nM}$ in the PIP4K2A ADP-Glo assay (low ATP), respectively. This slight potency improvement was also reflected in the HTRF assay, as well as in the high ATP setting. The chloro- and methyl-substituted analogues $(33,34)$ displayed biochemical potency values comparable to 17 , while branched substituents, 
Table 2. Peripheral Phenyl Ring SAR I ${ }^{a}$

\begin{tabular}{|c|c|c|c|c|c|}
\hline Compd & $\mathrm{R}^{2}$ & $\begin{array}{c}\text { PIP4K2A ADP-Glo, } \\
10 \mu \mathrm{M} \text { ATP } \\
\text { (LLE)/HTRF, } 10 \mu \mathrm{M} \\
\text { ATP, IC }{ }_{50}[\mu \mathrm{M}]\end{array}$ & $\begin{array}{c}\text { PIP4K2A ADP-Glo, } \\
250 \mu \mathrm{M} \text { ATP/HTRF, } \\
2 \mathrm{mM} \text { ATP } / / \mathrm{p}-\mathrm{AKT} \\
\text { HTRF THP-1, IC } \\
50 \\
{[\mu \mathrm{M}]}\end{array}$ & $\log \mathrm{D} / \mathrm{TPSA}$ & $\begin{array}{c}\text { Caco-2 } \\
P_{\text {app A-B }} \text { A-B } \\
{[\mathrm{nm} / \mathrm{s}] / \mathrm{ER}^{b}}\end{array}$ \\
\hline 32 & & $0.037(4.62) / 0.29$ & $0.22 / 3.07 / />50$ & $2.7 / 105$ & $140 / 0.6$ \\
\hline 33 & & $0.16(3.9) / \mathrm{nd}$ & $0.70 / \mathrm{nd} / />50$ & $2.9 / 105$ & nd \\
\hline 34 & & $0.11(4.03) / \mathrm{nd}$ & $0.92 / \mathrm{nd} / / \mathrm{nd}$ & $3.0 / 105$ & nd \\
\hline 35 & & $0.042(4.6) / 0.33$ & $0.28 / 2.43 / />50$ & $2.7 / 114$ & $160 / 0.8$ \\
\hline 36 & & $1.52(2.43) / \mathrm{nd}$ & $\mathrm{nd} / \mathrm{nd} / />50$ & $3.5 / 105$ & nd \\
\hline 37 & & $2.48(2.7) / \mathrm{nd}$ & $\mathrm{nd} / \mathrm{nd} / />50$ & $3.2 / 108$ & nd \\
\hline 38 & & $0.24(3.91) / \mathrm{nd}$ & $\mathrm{nd} / \mathrm{nd} / />50$ & $2.5 / 117$ & nd \\
\hline 39 & & $1.92(2.82) / \mathrm{nd}$ & $\mathrm{nd} / \mathrm{nd} / />50$ & $\mathrm{nd} / 125$ & nd \\
\hline 40 & & $1.02(2.85) / \mathrm{nd}$ & $7.93 / \mathrm{nd} / \mathrm{nd}$ & $3.1 / 105$ & nd \\
\hline 41 & & $0.52(3.94) / \mathrm{nd}$ & $2.16 / \mathrm{nd} / / \mathrm{nd}$ & $2.1 / 125$ & nd \\
\hline 42 & & $2.19(2.85) / \mathrm{nd}$ & $\mathrm{nd} / \mathrm{nd} / />50$ & $2.6 / 114$ & nd \\
\hline 43 & & $0.18(3.88) / \mathrm{nd}$ & $\mathrm{nd} / \mathrm{nd} / />50$ & $\mathrm{nd} / 105$ & nd \\
\hline 44 & & $0.074(4.07) / 0.56$ & $0.23 / 5.10 / />50$ & $3.1 / 105$ & $37 / 0.6$ \\
\hline 45 & & $0.061(4.24) / 0.36$ & $0.32 / 2.68 / />50$ & $3.0 / 105$ & nd \\
\hline 46 & & $0.20(3.88) / \mathrm{nd}$ & $1.17 / \mathrm{nd} / / \mathrm{nd}$ & $2.7 / 114$ & $104 / 0.7$ \\
\hline 47 & & $0.284(4.17) / \mathrm{nd}$ & $\mathrm{nd} / \mathrm{nd} / />50$ & $2.0 / 125$ & nd \\
\hline 48 & & $0.088(4.16) / \mathrm{nd}$ & $0.78 / \mathrm{nd} / />50$ & $2.7 / 105$ & nd \\
\hline
\end{tabular}


Table 2. continued

\begin{tabular}{|c|c|c|c|c|c|}
\hline Compd & $\mathrm{R}^{2}$ & $\begin{array}{l}\text { PIP4K2A ADP-Glo, } \\
10 \mu \mathrm{M} \text { ATP } \\
\text { (LLE)/HTRF, } 10 \mu \mathrm{M} \\
\text { ATP, } \mathrm{IC}_{50}[\mu \mathrm{M}]\end{array}$ & $\begin{array}{c}\text { PIP4K2A ADP-Glo, } \\
250 \mu \mathrm{M} \text { ATP/HTRF, } \\
2 \mathrm{mM} \text { ATP//p-AKT } \\
\text { HTRF THP-1, } \text { IC }_{50} \\
{[\mu \mathrm{M}]}\end{array}$ & $\log \mathrm{D} / \mathrm{TPSA}$ & $\begin{array}{c}\text { Caco-2 } \\
P_{\text {app A-B }} \text { A-B } \\
{[\mathrm{nm} / \mathrm{s}] / \mathrm{ER}^{b}}\end{array}$ \\
\hline 49 & & $0.30(3.41) / \mathrm{nd}$ & $1.49 / \mathrm{nd} / />50$ & $3.1 / 105$ & $29 / 0.5$ \\
\hline 50 & & $0.20(3.89) / \mathrm{nd}$ & $1.46 / \mathrm{nd} / / \mathrm{nd}$ & $2.7 / 114$ & $114 / 0.6$ \\
\hline 51 & & $0.66(3.84) / \mathrm{nd}$ & $\mathrm{nd} / \mathrm{nd} / />50$ & $2.0 / 118$ & nd \\
\hline 52 & & $10.2(2.83) / \mathrm{nd}$ & nd & $2.0 / 118$ & nd \\
\hline 53 & & $7.34(2.88) / \mathrm{nd}$ & nd & $2.0 / 118$ & nd \\
\hline 54 & & $18.0(2.63) / \mathrm{nd}$ & nd & $1.9 / 118$ & nd \\
\hline 55 & & $0.047(4.46) / 0.22$ & $0.57 / 2.44 / />50$ & $\mathrm{nd} / 114$ & nd \\
\hline 56 & & $0.32(3.69) / \mathrm{nd}$ & $\mathrm{nd} / \mathrm{nd} / />50$ & $\mathrm{nd} / 114$ & nd \\
\hline 57 & & $1.04(3.07) / \mathrm{nd}$ & $\mathrm{nd} / \mathrm{nd} / />50$ & $3.1 / 114$ & nd \\
\hline $\begin{array}{c}\mathbf{5 8} \\
(\mathrm{BAY}-297)\end{array}$ & & $0.013(4.87) / 0.11$ & $0.069 / 0.77 / />50$ & $3.1 / 105$ & $39 / 0.5$ \\
\hline 59 & & $0.019(4.73) / 0.17$ & $0.071 / 1.30 / />50$ & $3.0 / 105$ & $47 / 0.5$ \\
\hline
\end{tabular}

${ }^{a} \mathrm{IC}_{50}$ values are arithmetic means of multiple measurements. $\mathrm{nd}=$ not determined. ${ }^{b} \mathrm{ER}=$ efflux ratio.

as in compounds 36 and $\mathbf{3 7}$, or extended side chains, as in derivatives 41-42, led to a significant loss in biochemical activity. With respect to the meta position, compounds with sterically small groups, as in 43-47, showed acceptable biochemical potencies, with the chloro- and methyl-substituted analogues [44 and 45, ADP-Glo assay (low ATP): 74 and 61 $\mathrm{nM}$, respectively] being most effective. A similar picture emerged for compounds with a para-substituted phenyl ring (48-50), with fluorine derivative 48 being equipotent to the initial reference compound $\mathbf{1 7}$. We also performed a nitrogen scan for the peripheral phenyl ring. Relative to the $o$-methylsubstituted phenyl ring derivative $(34,110 \mathrm{nM})$, we observed a significant drop in biochemical potency in the ADP-Glo assay (low ATP) for all four possible pyridine analogues 51-54 investigated. When tested in the Caco- 2 assay, selected carboxamides $(32,35,44,46,49-50,58,59)$ displayed acceptable to good permeability in the apical to basolateral direction and low efflux ratios, indicating a high likelihood for oral absorption. Finally, compounds with various disubstitution patterns in the phenyl ring, as in 55-59, were investigated with the aim of realizing synergistic effects between the different substituents. Disubstituted analogues 55-57 with a methyl ether at the ortho position did not show synergistic potency improvements. In contrast, ortho/meta-disubstituted analogues with fluorine at the ortho position of the peripheral phenyl ring, as in compounds $\mathbf{5 8}$ and 59, did show improved biochemical potencies compared with the monofluorosubstituted phenyl ring analogue 32, with $\mathrm{IC}_{50}$ values of 13 and $19 \mathrm{nM}$ in the ADP-Glo assay (low ATP), respectively. This improvement was also reflected in improved biochemical potencies in the HTRF assay, as well as in the medium/high ATP setting. Compound 58 (BAY-297) represented the first example of this carboxamide series with submicromolar biochemical potency in the high ATP $(2 \mathrm{mM})$ HTRF assay and was therefore selected for in-depth profiling (see Figure 6).

We then looked into transferring the peripheral phenyl ring SAR to the carboxylic acid series (Table 3 ). As exemplarily shown for compounds 60 and 61, potencies for the most effective substitution pattern translated well from the carboxamide to the carboxylic acid series. Acids 60 and 61 again displayed significantly higher potency values across the different biochemical assay formats when compared with their carboxamide counterparts 58 and 59. As expected, both carboxylic acids showed very poor permeability in the apical to basolateral direction in the Caco-2 assay, which indicates a low probability for an acceptable absorption after oral dosing. Nevertheless, carboxylic acid 60 (BAY-091), a 16 nM PIP4K2A inhibitor in the high ATP (2 mM) HTRF assay, was selected for additional in-depth profiling (see Figure 7 ).

Upon investigation of the core SAR (Table 4), it became evident that replacement of the 3-cyano-1,7-naphthyridine core structure, as in $\mathbf{1}$, by a pyrido $[3,4-d]$ pyrimidine core, as in $\mathbf{6 3}$, 


\begin{tabular}{|l|c|}
\hline \multicolumn{2}{|l|}{ Pharmacological in vitro Properties } \\
\hline PIP4K2A ADP Glo $10 \mu \mathrm{M}$ ATP IC & $13 \mathrm{nM}$ \\
\hline PIP4K2A ADP Glo $250 \mu \mathrm{M}$ ATP IC & $69 \mathrm{nM}$ \\
\hline PIP4K2A HTRF $10 \mu \mathrm{M}$ ATP IC ${ }_{50}$ & $110 \mathrm{nM}$ \\
\hline PIP4K2A HTRF $2 \mathrm{mM}$ ATP IC $C_{50}$ & $769 \mathrm{nM}$ \\
\hline
\end{tabular}

\begin{tabular}{|c|c|}
\hline \multicolumn{2}{|c|}{ Physicochemical Properties } \\
\hline MW corr [g*mol] & 430 \\
\hline TPSA $\left[A^{2}\right]$ & 105 \\
\hline LogD @pH 7.5 & 3.1 \\
\hline $\mathrm{Sw} \mathrm{pH} 6.5[\mathrm{mg} / \mathrm{L}]$ & $<0.1$ \\
\hline Stability, pH & stable \\
\hline
\end{tabular}

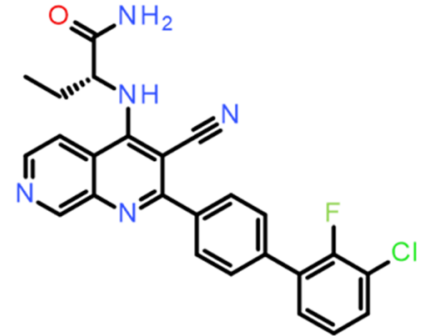

58, BAY-297

PIP4K2A Inhibitor

Safety Properties

\begin{tabular}{|l|l|}
\hline hERG $[\mu \mathrm{M}]$ & 3.1 \\
\hline
\end{tabular}

\begin{tabular}{|c|c|c|c|c|c|c|}
\hline \multicolumn{7}{|c|}{ In vitro DMPK Properties } \\
\hline \multirow{2}{*}{$\begin{array}{l}\text { Caco2 } \\
\text { permeability }\end{array}$} & \multicolumn{2}{|c|}{$P_{\text {app }}(A-B)[n m / s]$} & \multicolumn{2}{|c|}{$P_{\text {app }}(B-A)[n m / s]$} & \multicolumn{2}{|c|}{ efflux ratio } \\
\hline & \multicolumn{2}{|c|}{39} & \multicolumn{2}{|c|}{19} & \multicolumn{2}{|r|}{0.5} \\
\hline \multirow{2}{*}{ PAMPA } & \multicolumn{2}{|c|}{$P_{\mathrm{app}}(\mathrm{A}-\mathrm{B})[\mathrm{nm} / \mathrm{s}]$} & \multicolumn{4}{|c|}{ Recovery [\%] } \\
\hline & \multicolumn{2}{|c|}{3.1} & \multicolumn{4}{|c|}{18} \\
\hline \multirow{3}{*}{$\begin{array}{l}\text { metabolic } \\
\text { stability }\end{array}$} & & & \multicolumn{2}{|c|}{$\mathrm{CL}[\mathrm{L} / \mathrm{h} / \mathrm{kg}]$} & \multicolumn{2}{|r|}{$\mathbf{F}_{\max }[\%]$} \\
\hline & \multicolumn{2}{|c|}{ liver microsomes $(\mathrm{h} / \mathrm{r})$} & \multicolumn{2}{|c|}{$0 / 0.14$} & \multicolumn{2}{|r|}{$100 / 97$} \\
\hline & \multicolumn{2}{|c|}{ hepatocytes (r) } & \multicolumn{2}{|c|}{0.3} & \multicolumn{2}{|r|}{93} \\
\hline \multirow{2}{*}{$\begin{array}{l}\text { CYP inhibition } \\
\text { IC }_{50}[\mu \mathrm{M}]\end{array}$} & $1 \mathrm{~A} 2$ & $2 \mathrm{C} 8$ & $2 \mathrm{Cg}$ & 2D6 & 3A4 & 3A4 preinc. \\
\hline & $>10$ & 2.3 & 3.4 & $>10$ & 10 & 8.35 \\
\hline
\end{tabular}

Figure 6. Pharmacological, physicochemical, safety, and in vitro DMPK properties of 58 (BAY-297).

\section{Table 3. Peripheral Phenyl Ring SAR II ${ }^{a}$}

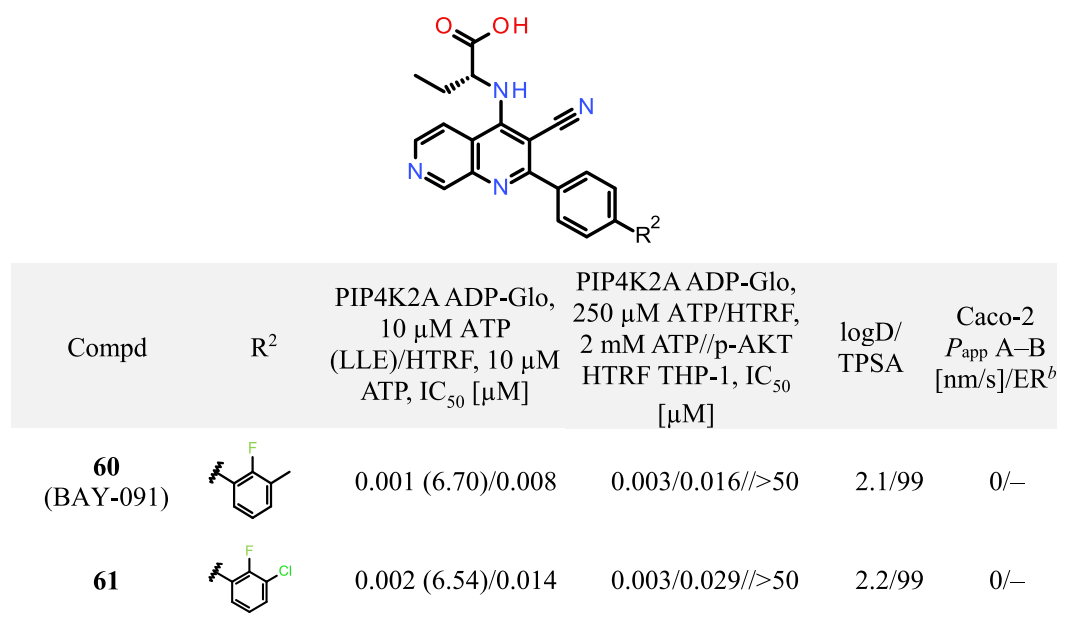

${ }^{a} \mathrm{IC}_{50}$ values are arithmetic means of multiple measurements. ${ }^{b} \mathrm{ER}=$ efflux ratio.

is not well tolerated by PIP4K2A. On the other hand, the introduction of a chlorine atom at position C-5 of the 1,7naphthyridine core, as in carboxamide $\mathbf{6 2}$, is well tolerated and resulted in a significant improvement in biochemical potency and lipophilic ligand efficiency (LLE), most likely due to an additional halogen interaction ${ }^{19}$ with $\mathrm{Phe}^{200}$ (see Figure 2B). However, chlorine introduction also led to a significant increase in lipophilicity $(\log D$ at $\mathrm{pH} 7.5)$ and decreased permeability in the Caco-2 assay ( $\mathrm{A}-\mathrm{B}$ value), which indicated an upper threshold for maximum tolerated overall lipophilicity.

A recurring characteristic of these lead series was the absence of any significant activity in the cellular mechanistic phospho-AKT (p-AKT) HTRF assay for all derivatives tested (compounds in Tables 1-4). Up to this point, it remained unknown as to whether insufficient PIP4K2A inhibitory potency of carboxamides or limited cellular permeability of carboxylic acids might be a contributor to this in vitro activity disconnect and whether Caco-2 permeability might be a meaningful indicator of cell permeability limitations in the carboxylic acid series. We therefore tested the ability of selected compounds to permeate through a lipid-infused artificial membrane in a parallel artificial membrane permeability assay (PAMPA, Table 5), which measures the ability of a compound to permeate from its donor compartment into a drug-free acceptor compartment. The PAMPA results confirmed good permeabilities for the carboxamides inves- 


\begin{tabular}{|c|c|}
\hline \multicolumn{2}{|c|}{ Pharmacological in vitro Properties } \\
\hline PIP4K2A ADP Glo $10 \mu \mathrm{M}$ ATP IC 50 & $1 \mathrm{nM}$ \\
\hline PIP4K2A ADP Glo $250 \mu \mathrm{M}$ ATP IC ${ }_{50}$ & $3 \mathrm{nM}$ \\
\hline PIP4K2A HTRF $10 \mu \mathrm{M}$ ATP IC ${ }_{50}$ & $8 \mathrm{nM}$ \\
\hline PIP4K2A HTRF 2 mM ATP IC 50 & $16 \mathrm{nM}$ \\
\hline
\end{tabular}

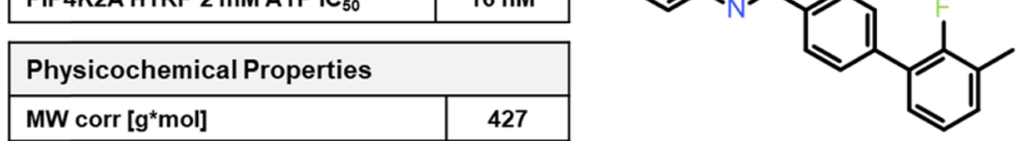

\begin{tabular}{|l|c|}
\hline MW corr $\left[\mathrm{g}^{\star} \mathrm{mol}\right]$ & 427 \\
\hline TPSA $\left[\AA^{2}\right]$ & 99 \\
\hline LogD @pH 7.5 & 2.1 \\
\hline Sw pH $6.5[\mathrm{mg} / \mathrm{L}]$ & $>1000$ \\
\hline Stability, $\mathrm{pH}$ & stable \\
\hline
\end{tabular}

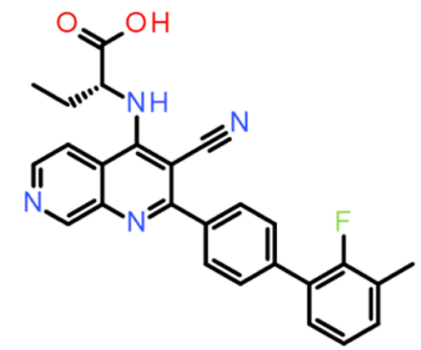

60, BAY-091 PIP4K2A Inhibitor

\begin{tabular}{|l|l|}
\hline \multicolumn{2}{|l|}{ Safety Properties } \\
\hline hERG $[\mu \mathrm{M}]$ & $>10$ \\
\hline
\end{tabular}

\begin{tabular}{|c|c|c|c|c|c|c|}
\hline \multicolumn{7}{|c|}{ In vitro DMPK Properties } \\
\hline \multirow{2}{*}{$\begin{array}{l}\text { Caco2 } \\
\text { permeability }\end{array}$} & \multicolumn{2}{|c|}{$P_{\text {app }}(A-B)[n m / s]$} & \multicolumn{2}{|c|}{$P_{\text {app }}(B-A)[n m / s]$} & \multicolumn{2}{|c|}{ efflux ratio } \\
\hline & \multicolumn{2}{|c|}{0} & \multicolumn{2}{|c|}{257} & \multicolumn{2}{|r|}{ - } \\
\hline \multirow{2}{*}{ PAMPA } & \multicolumn{2}{|c|}{$P_{\text {app }}(A-B)[n m / s]$} & \multicolumn{4}{|c|}{ Recovery [\%] } \\
\hline & \multicolumn{2}{|c|}{14} & \multicolumn{4}{|c|}{66} \\
\hline \multirow{3}{*}{$\begin{array}{l}\text { metabolic } \\
\text { stability }\end{array}$} & & & \multicolumn{2}{|c|}{$\mathrm{CL}[\mathrm{L} / \mathrm{h} / \mathrm{kg}]$} & \multicolumn{2}{|c|}{$\mathbf{F}_{\max }[\%]$} \\
\hline & \multicolumn{2}{|c|}{ liver microsomes (h/r) } & \multicolumn{2}{|c|}{$0 / 2.8$} & \multicolumn{2}{|c|}{$100 / 33$} \\
\hline & \multicolumn{2}{|c|}{ hepatocytes (r) } & \multicolumn{2}{|c|}{2.3} & \multicolumn{2}{|r|}{44} \\
\hline \multirow{2}{*}{$\begin{array}{l}\text { CYP inhibition } \\
\text { IC }_{50}[\mu \mathrm{M}]\end{array}$} & $1 \mathrm{~A} 2$ & $2 \mathrm{C} 8$ & $2 \mathrm{C} 9$ & $2 \mathrm{D} 6$ & 3A4 & 3A4 preinc. \\
\hline & $>20$ & 3.1 & 16 & $>20$ & $>20$ & $>20$ \\
\hline
\end{tabular}

Figure 7. Bio-/physicochemical, safety, and in vitro DMPK properties of 60 (BAY-091).

Table 4. SAR of the Naphthyridine Core ${ }^{a}$

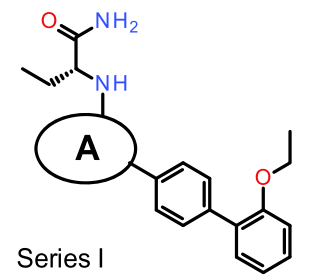

PIP4K2A ADP-Glo,

\begin{tabular}{|c|c|c|c|c|c|c|}
\hline Compd & Series & A & $\begin{array}{l}\text { PIP4K2A ADP-Glo, } \\
10 \mu \mathrm{M} \text { ATP } \\
\text { (LLE)/HTRF, } 10 \mu \mathrm{M} \\
\text { ATP, } \mathrm{IC}_{50}[\mu \mathrm{M}]\end{array}$ & $\begin{array}{c}\text { PIP4K2A ADP-Glo, } \\
250 \mu \mathrm{M} \text { ATP/HTRF, } \\
2 \mathrm{mM} \text { ATP//p-AKT } \\
\text { HTRF THP- } 1, \mathrm{IC}_{50} \\
{[\mu \mathrm{M}]}\end{array}$ & $\begin{array}{l}\log \mathrm{D} / \\
\text { TPSA }\end{array}$ & $\begin{array}{c}\text { Caco-2 } \\
P_{\text {app A-B }} \text { A-B } \\
{[\mathrm{nm} / \mathrm{s}] / \mathrm{ER}^{b}}\end{array}$ \\
\hline 17 & I & & $0.089(4.03) / 0.45$ & $0.38 / 11.2 / / \mathrm{nd}$ & $3.0 / 114$ & $151 / 0.5$ \\
\hline 62 & I & & $0.007(4.79) / 0.03$ & $0.02 / 0.21 / />50$ & $3.7 / 114$ & $17 / 0.5$ \\
\hline $\begin{array}{c}1 \\
(r a c)\end{array}$ & II & & $0.014(5.61) / \mathrm{nd}$ & $0.051 / \mathrm{nd} / / \mathrm{nd}$ & $2.1 / 108$ & $0 /-$ \\
\hline $\begin{array}{c}\mathbf{6 3} \\
(\mathrm{rac})\end{array}$ & II & & $5.03(3.0) / \mathrm{nd}$ & nd & $2.1 / 97$ & nd \\
\hline
\end{tabular}

${ }^{a} \mathrm{IC}_{50}$ values are arithmetic means of multiple measurements. $\mathrm{nd}=$ not determined. ${ }^{b} \mathrm{ER}=$ efflux ratio.

tigated. In contrast to the Caco-2 assay, carboxylic acid derivatives, such as $1,10,24$, and 60 , also permeated with moderate velocity from the apical to basolateral direction. In this assay, there were low compound recovery values for amides $\mathbf{1 7}$ and 58, which nicely reflects their relatively high overall lipophilicity. From these data, one would expect the carboxylic acids to passively pass a cellular membrane, although at a slower pace than the corresponding carboxamides.

Synthesis and Characterization of Advanced Leads 58 and 60. The synthesis of 58 (BAY-297) and 60 (BAY091) (Scheme 2) followed the route previously outlined for 2. For 60 (BAY-091), bromonaphthyridine $\mathbf{8 b}$ was transformed into tert-butyl ester 9 , which was cleaved to give carboxylic acid 10. Subsequent Suzuki coupling using (2-fluoro-3-methyl- 
Table 5. PAMPA $_{\mathrm{A}-\mathrm{B}}$ vs Caco- $\mathrm{2}_{\mathrm{A}-\mathrm{B}}$ Permeability Values

\begin{tabular}{cccc} 
compd & $\log D$ & PAMPA $_{\mathrm{A}-\mathrm{B}}[\mathrm{nm} / \mathrm{s}]($ recovery \%) & Caco-2 ${ }_{\mathrm{A}-\mathrm{B}}[\mathrm{nm} / \mathrm{s}]$ \\
$\mathbf{1}$ & 2.1 & $10(71)$ & 0.0 \\
$\mathbf{1 0}$ & 1.6 & $5.9(86)$ & 0.0 \\
$\mathbf{1 2}$ & 2.2 & $88(71)$ & 202 \\
$\mathbf{1 7}$ & 3.0 & $18(23)$ & 151 \\
$\mathbf{2 4}$ & 2.2 & $2.6(68)$ & 0.0 \\
$\mathbf{5 8}$ & 3.1 & $3.1(18)$ & 39 \\
$\mathbf{6 0}$ & 2.1 & $14(66)$ & 0.0 \\
\hline
\end{tabular}

phenyl) boronic acid furnished advanced lead compound $\mathbf{6 0}$. Compound 58 (BAY-297) was also synthesized from $\mathbf{8 b}$, which was transformed into carboxamide 12 and further converted into the final compound $\mathbf{5 8}$ under Suzuki coupling conditions using (3-chloro-2-fluorophenyl) boronic acid.

Advanced tool compounds 58 (BAY-297) and 60 (BAY091) were profiled in pharmacological, physicochemical, and DMPK assays in vitro (Figures 6 and 7).

Carboxamide 58 (BAY-297) had an $\mathrm{IC}_{50}$ value of $13 \mathrm{nM}$ in the biochemical PIP4K2A ADP-Glo assay containing $10 \mu \mathrm{M}$ ATP (low ATP), which translated to an $\mathrm{IC}_{50}$ value of $69 \mathrm{nM}$ in the assay containing $250 \mu \mathrm{M}$ ATP (medium ATP). In the PIP4K2A HTRF assay containing $10 \mu \mathrm{M}$ ATP (low ATP) or 2 mM ATP (high ATP), 58 displayed $\mathrm{IC}_{50}$ values of 110 and 769 $\mathrm{nM}$, respectively. Carboxylic acid 60 showed 10-20-fold higher inhibitory potency in the ADP-Glo assay as well as in the low ATP HTRF assay format. The most striking difference between the two tool compounds was seen in the high ATP PIP4K2A HTRF assay, with acid 60 being a $16 \mathrm{nM}$ inhibitor, which is a 48 -fold improvement in inhibitory potency over amide 58 .
Carboxylic acid 60 displayed drug-like physicochemical properties with favorable lipophilicity $(\log D)$, TPSA, and aqueous solubility $\left(S_{\mathrm{w}}\right)$ and exhibited high metabolic stability in human and rat liver microsomes as well as in rat hepatocytes (Figure 7). However, acid $\mathbf{6 0}$ again showed no permeation in the apical to basolateral direction $\left(P_{\text {app }} \mathrm{A}-\mathrm{B}=0\right)$ in the Caco2 assay, which indicates unfavorable oral absorption properties. Conversion of the carboxylic acid moiety in $\mathbf{6 0}$ into a primary carboxamide in tool compound $\mathbf{5 8}$ leads to an increase in lipophilicity at $\mathrm{pH} 7.5$ of one log unit and, more importantly, to a significant reduction in aqueous solubility. However, metabolic stability of $\mathbf{5 8}$ remained unaffected by the increase in lipophilicity, with predicted maximal oral bioavailability $\left(F_{\max }\right)$ values in human and rat liver microsomes, as well as in rat hepatocytes, being greater than 90\%. Compared with carboxylic acid 60, carboxamide 58 displayed acceptable permeation in the apical to basolateral direction $\left(P_{\text {app }} \mathrm{A}-\mathrm{B}=\right.$ $39 \mathrm{~nm} / \mathrm{s}$ ) in the Caco-2 assay, with no significant efflux.

Additional investigated parameters included CYP inhibition as an indicator of possible drug-drug interactions (DDI) and hERG inhibition as a cardiac safety parameter. Compared with carboxamide 58, carboxylic acid 60 exhibits a superior profile with no significant hERG interaction up to $10 \mu \mathrm{M}$ and moderate CYP2C8 inhibition $\left(\mathrm{IC}_{50}=3.1 \mu \mathrm{M}\right)$ as the only significant initial DDI signal. In contrast, amide 58 inhibits the hERG channel with an $\mathrm{IC}_{50}$ value of $3.1 \mu \mathrm{M}$ and CYP2C8 and CYP2C9 with $\mathrm{IC}_{50}$ values of around $2-3 \mu \mathrm{M}$ and, in addition, showed time-dependent inhibition of CYP3A4 with an $\mathrm{IC}_{50}$ value of $8.3 \mu \mathrm{M}$.

Taken together, our results indicate that future lead optimization efforts for the carboxylic acid series will need to focus on improving oral absorption properties, while, for the primary carboxamide series, an improvement in aqueous

Scheme 2. Synthesis of 58 (BAY-297) and $60(\text { BAY-091 })^{a}$
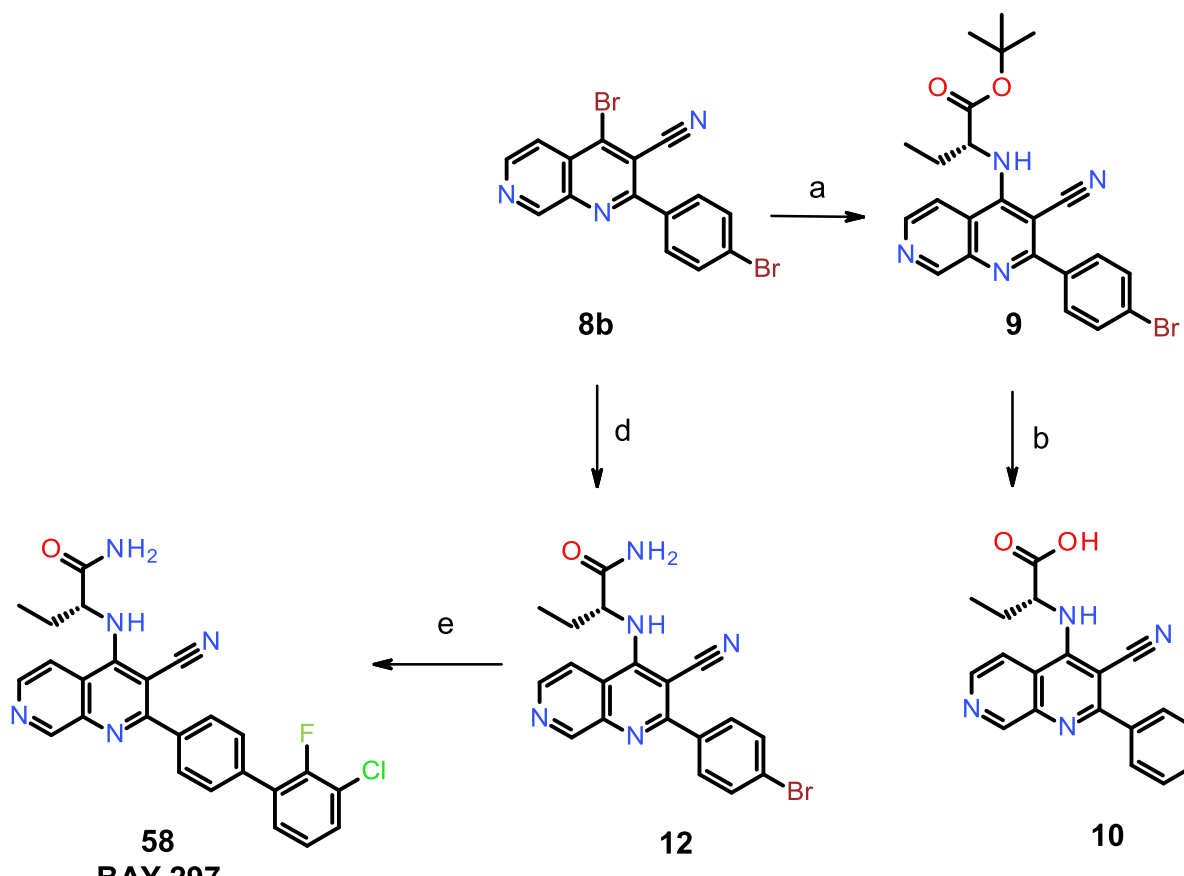

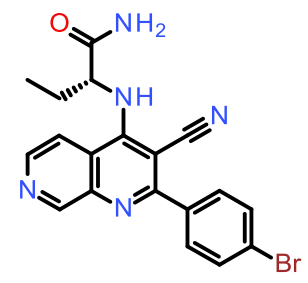

12

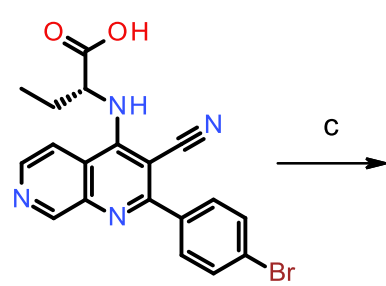

10

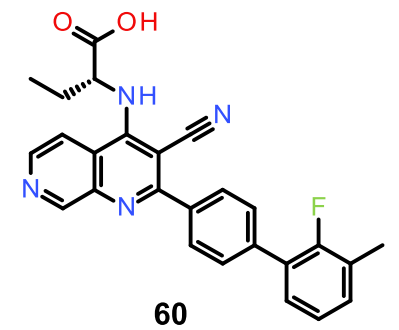

BAY-091

${ }^{a}$ Reagents and conditions: (a) (R)-2-Aminobutanoate hydrochloride, $\mathrm{Et}_{3} \mathrm{~N}$, DMF, 89\%; (b) HCl, 1,4-dioxane, 57\%; (c) (2-fluoro-3methylphenyl)boronic acid, XPhos Pd G2, potassium phosphate, THF, $\mathrm{H}_{2} \mathrm{O}, 19 \%$; (d) (2R)-2-aminobutanamide hydrochloride, Et ${ }_{3} \mathrm{~N}, \mathrm{DMF}, 96 \%$; (e) (3-chloro-2-fluorophenyl)boronic acid, XPhos Pd G2, potassium phosphate, THF, $\mathrm{H}_{2} \mathrm{O}, 52 \%$. 

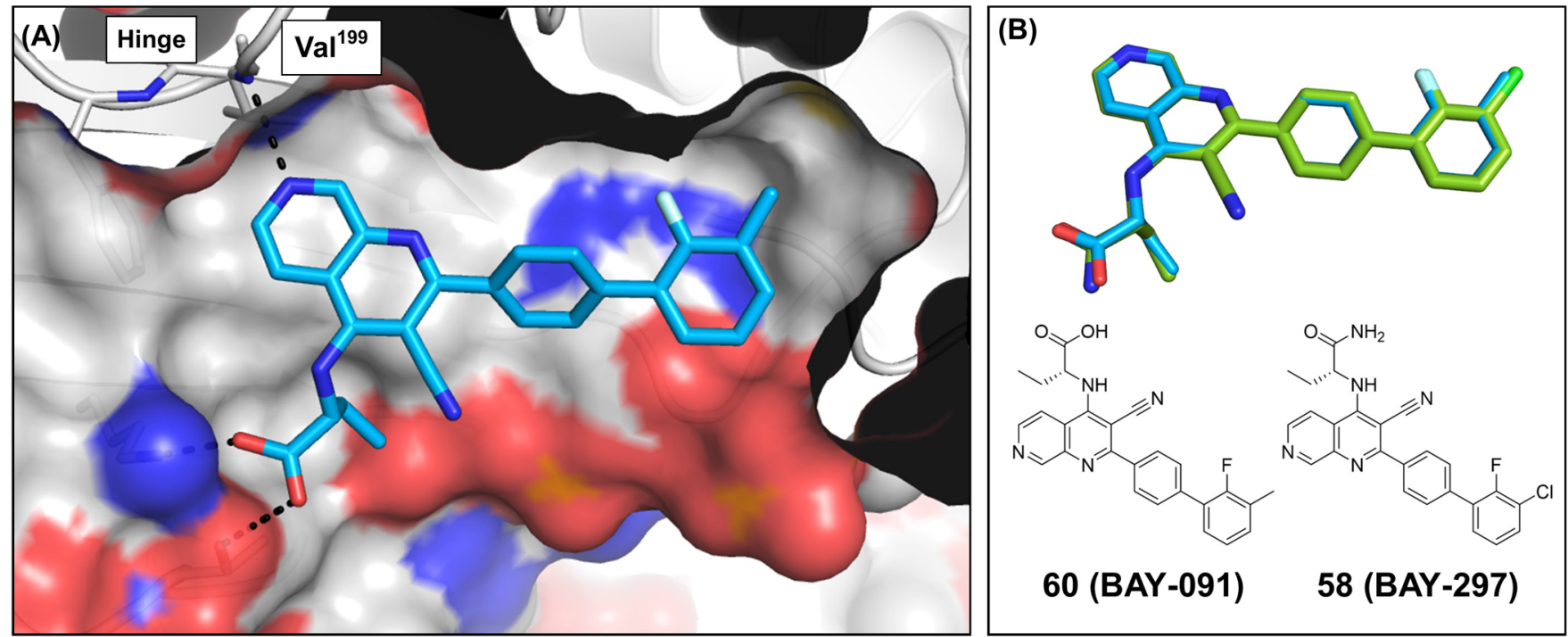

Figure 8. X-ray analysis of compound 60 (BAY-091). (A) Surface representation of PIP4K2A (C, N, and O atoms colored white, blue, and red, respectively). Compound 60 is shown in stick representation with $\mathrm{C}, \mathrm{N}, \mathrm{O}$, and $\mathrm{F}$ atoms colored turquoise, blue, red, and pale blue, respectively. Key interactions between $\mathbf{6 0}$ and the protein are shown as black dotted lines. (B) Overlay of $\mathbf{6 0}$ (turquoise) and $\mathbf{5 8}$ (green). Compound structures are superimposed based on the superimposition of cocrystal PIP4K2A structures. The two protein structures share an rmsd of $0.3 \AA$ over 313 equivalent $\mathrm{C} \alpha$ atoms.

PIP4K2A Intact Cells - BAY-091

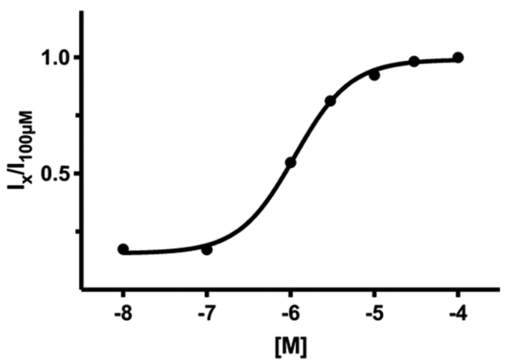

PIP4K2A Lysate - BAY-091

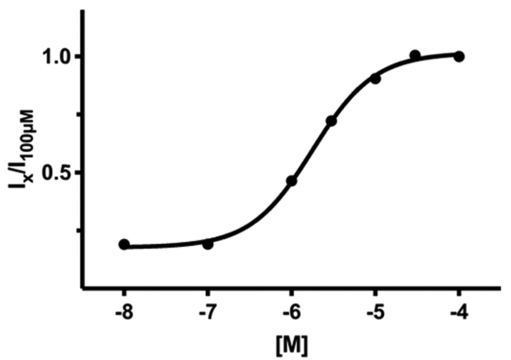

PIP4K2A Intact Cells - BAY-297

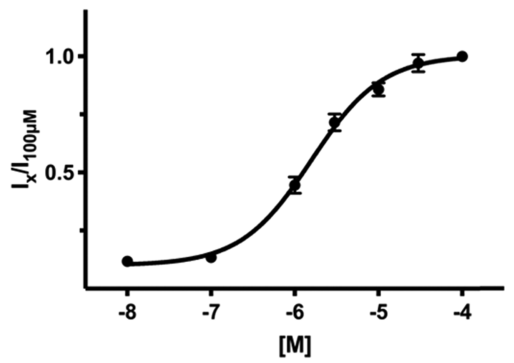

PIP4K2A Lysate - BAY-297

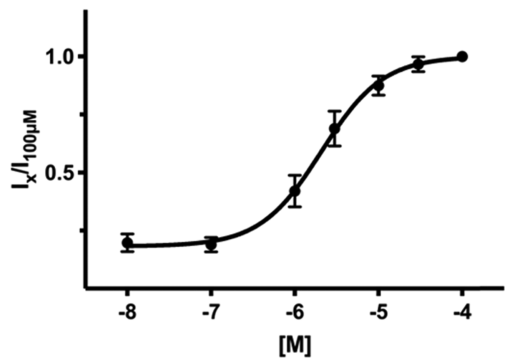

Figure 9. Cellular thermal shift assay experiments. Concentration-response curves for PIP4K2A with 58 (BAY-297) and 60 (BAY-091) in intact THP-1 cells (at $56{ }^{\circ} \mathrm{C}$ ) and cell lysates (at $60{ }^{\circ} \mathrm{C}$ ).

solubility together with careful monitoring of overall compound lipophilicity as well as DDI and cardiac ion channel properties requires major attention.

Compounds 58 (BAY-297) and 60 (BAY-091) were tested in a commercial kinase panel (Millipore, 373 kinases) at $1 \mu \mathrm{M}$ compound concentration (see the Supporting Information, Tables S2 and S3). Besides PIP4K2A, none of the potential offtarget kinases was inhibited $>60 \%$, which underscores the excellent kinase selectivity profile of both $\mathbf{5 8}$ and $\mathbf{6 0}$.

X-ray cocrystal structures of $\mathbf{5 8}$ (BAY-297, PDB 6YM4) and 60 (BAY-091, PDB 6YM5) in complex with PIP4K2A revealed binding modes conserved with that of the initial lead compound $\mathbf{1}$ (cf. Figures $2 \mathrm{~B}$ and 8). The ortho/meta substituents of the peripheral phenyl ring are accommodated within the hydrophobic subpocket and form a number of potency-increasing van der Waals-type interactions with adjacent residues. The carboxylic acid moiety of compounds $\mathbf{1}$ and $\mathbf{6 0}$ is mimicked by the carboxamide group of $\mathbf{5 8}$.

To investigate the likelihood of 60 (BAY-091) additionally inhibiting the PIP4K2B and PIP4K2C isoforms, we analyzed the sequence conservation of residues contained within the $\mathbf{6 0}$ binding site (see the Supporting Information, Figure S1). While PIP4K2A residues forming hydrogen-bonding and electronic stacking interactions with 60 are conserved in 
A

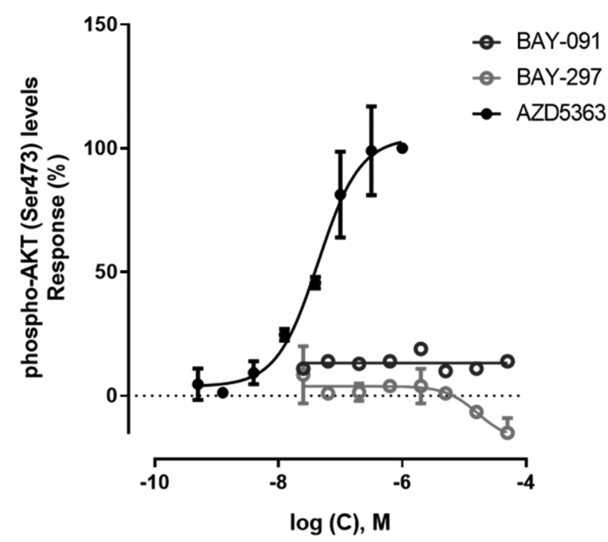

B

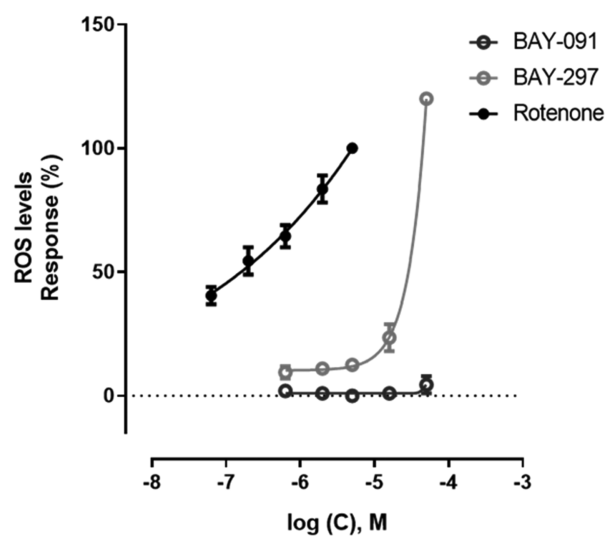

Figure 10. Phospho-AKT and ROS cellular mechanistic assays with THP-1 cells. (A) Phospho-AKT (Ser ${ }^{473}$ ) levels measured with a commercially available HTRF assay kit (Cisbio) after treatment for $2 \mathrm{~h}$ with the indicated compounds and concentrations. AZD5363, an ATP-competitive AKT inhibitor known to increase p-AKT levels (both $\mathrm{Ser}^{473}$ and $\mathrm{Th}^{308}$ ) despite blockage of downstream signaling, ${ }^{21}$ was used as a positive control. (B) ROS levels measured using MitoSOX Red and FACS after treatment for $1 \mathrm{~h}$ with the indicated compounds and concentrations. Mitochondrial complex I inhibitor rotenone was used as a positive control.

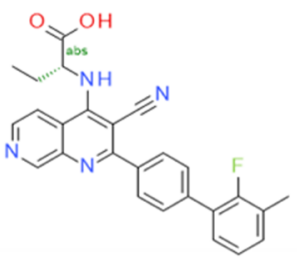

60, (BAY-091)

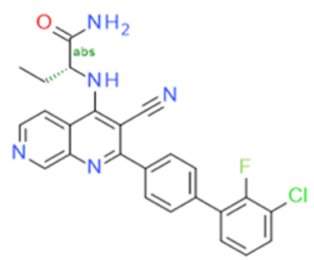

58, (BAY-297)

\begin{tabular}{|c|c|c|}
\hline $\begin{array}{c}\text { PIP4K2A kinase assay, ADP Glo, } \\
10 \mu \mathrm{M} / 250 \mu \mathrm{M} \text { ATP, } \mathrm{IC}_{50}[\mathrm{nM}]\end{array}$ & $1.3 / 2.6$ & $13.1 / 68.6$ \\
\hline $\begin{array}{c}\text { PIP4K2A kinase assay, HTRF, } \\
10 \mu \mathrm{M} / 2 \mathrm{mM} \text { ATP, } \mathrm{IC}_{50}[\mathrm{nM}]\end{array}$ & $8.5 / 16.4$ & $110 / 769$ \\
\hline $\begin{array}{c}\text { CETSA lysates, } \\
60^{\circ} \mathrm{C}, \mathrm{EC}_{50}(95 \% \mathrm{CI})[\mu \mathrm{M}]\end{array}$ & $1.8(1.4-2.2)$ & $2.1(1.4-3.1)$ \\
\hline $\begin{array}{c}\text { CETSA int. cells, } \\
56^{\circ} \mathrm{C}, \mathrm{EC}_{50}(95 \% \mathrm{CI})[\mu \mathrm{M}]\end{array}$ & $1.1(0.9-1.4)$ & $1.6(1.2-2.0)$ \\
\hline $\begin{array}{l}\text { Cellular mechanistic assay, } \\
\text { p-AKT HTRF, THP-1, EC } \text { E0 }_{50}[\mu \mathrm{M}]\end{array}$ & $>\mathbf{5 0}$ & $>\mathbf{5 0}$ \\
\hline $\begin{array}{l}\text { Cellular mechanistic assay, } \\
\text { ROS levels, THP-1, } \mathrm{EC}_{50}[\mu \mathrm{M}]\end{array}$ & $>\mathbf{5 0}$ & 18.1 \\
\hline $\begin{array}{l}\text { 2D anti-proliferation, } \\
\text { THP-1 (p53 mut) }[\mu \mathrm{M}]\end{array}$ & $>30$ & $\approx 30$ \\
\hline $\begin{array}{l}\text { 2D anti-proliferation, } \\
\text { EBC-1 (p53 mut) }[\mu \mathrm{M}]\end{array}$ & $\approx 30$ & 9.5 \\
\hline $\begin{array}{c}2 D \text { anti-proliferation, } \\
\text { NCI-H460 (p53 WT) [MM] }\end{array}$ & $>\mathbf{3 0}$ & 21.2 \\
\hline
\end{tabular}

Figure 11. Biochemical and cellular assay results for 58 (BAY-297) and 60 (BAY-091).

both PIP4K2B and PIP4K2C, some other residues in the binding site that form additional van der Waals-type interactions with $\mathbf{6 0}$ are not completely conserved. These differences between the PIP4K2A and PIP4K2B binding sites are limited to minor conservative residue differences that are not expected to sterically disrupt 60 binding. A similar comparison of the PIP4K2A and PIP4K2C proteins identified similar minor residue differences in the two binding pockets accompanied by a potentially more significant difference in the gatekeeper residue, whereby the PIP4K2A threonine is replaced by methionine in the PIP4K2C isoform. This suggests that 60 may have reduced PIP4K2C protein inhibitory activity. A sequence alignment of the three isoforms identified further sequence divergence within the P-loop flanking that ATP 
binding site. Since the region of the protein was structurally disordered in our complex structures, it was not possible to evaluate the potential structural impact of such differences upon inhibitor binding.

Biochemical assays for PIP4K2B and PIP4K2C were not available during the course of our studies but would have been important to validate the sequence and structure-based comparison described here, as well as support further pharmacological characterization of 60 (BAY-091).

Cellular Mechanistic and Anti-proliferation Assays. Given the absence of any significant activity in the cellular mechanistic p-AKT HTRF assay for all compounds tested, we undertook cellular thermal shift assay (CETSA) ${ }^{20}$ experiments to check target engagement within cells. These experiments were performed with THP-1 cell lysates as well as intact cells. Interestingly, both 58 (BAY-297) and 60 (BAY-091) induced a dose-dependent thermal shift, with similar $\mathrm{EC}_{50}$ values, in THP-1 lysates (2.1 and $1.8 \mu \mathrm{M}$, respectively) and intact cells (1.6 and $1.1 \mu \mathrm{M}$, respectively) (Figure 9), thereby confirming their binding to the PIP4K2A protein in these cellular systems. These findings are in agreement with our earlier PAMPA results (see Table 5) predicting permeability for carboxamide 58 and carboxylic acid $\mathbf{6 0 .}$

As a next step, we initiated an evaluation of the downstream cellular effects of treating THP-1 cells with PIP4K2A inhibitors. According to our literature-based hypothesis, such inhibitors were expected to increase the phospho levels of AKT (Ser ${ }^{473}$ and $\mathrm{Thr}^{308}$ ). Surprisingly, the PIP4K2A inhibitors, tested up to a concentration of $50 \mu \mathrm{M}$, did not increase the levels of p-AKT $\left(\mathrm{Ser}^{473}\right.$ and $\mathrm{Thr}^{308}$ ) in THP-1 cells, as determined by HTRF (Figure 10) and western blot (see the Supporting Information, Figure S3). Ramel and co-workers have shown that PI5P, the substrate of PIP4K2A, is able to protect AKT from dephosphorylation by phosphorylating protein phosphatase 2 (PP2A) Tyr307, thereby inhibiting the catalytic subunit of PP2A. ${ }^{6}$ Therefore, we investigated the effect of PIP4K2A inhibitors on p-PP2A ( $\left.\mathrm{Tyr}^{307}\right)$ levels. Consistent with the lack of effect on p-AKT, the PIP4K2A inhibitors were unable to induce changes in the p-PP2A $\left(\mathrm{Tyr}^{307}\right.$ ) protein levels (Figure S3). Finally, we evaluated the mitochondrial ROS levels in THP-1 cells treated with PIP4K2A inhibitors. However, once again, no consistent effects were observed (Figure 10).

Although these results are not supportive of our initial disease hypothesis, we addressed whether PIP4K2A inhibitors are able to reduce the cell viability of $\mathrm{p} 53$ mutant and wild-type cell lines, potentially by a different mechanism. Interestingly, only weak antiproliferative activity was observed for $\mathbf{5 8}$ (BAY297) in two out of three cell lines tested, an effect that was not dependent on p53 status (Figure 11). Thus, we were unable to confirm the proposed synthetic lethality between PIP4K2A inhibition and p53 deficiency using ATP-competitive smallmolecular tool compounds.

As evidenced by our results, good biochemical potency and cellular target engagement of PIP4K2A inhibitors did not translate into the anticipated mode of action and/or antiproliferative activity. In contrast, Kitagawa and co-workers have described an inhibitor of PIP4Ks that selectively kills cancer cells. Interestingly, the activity of this compound does not depend on the p53 status of the tumor cells, which suggests that other targets, in addition to PIP4Ks, are inhibited as well, thereby indicating a poor selectivity profile. $^{22}$ Importantly, our results are at odds with literature data suggesting that PIP4K2A inhibition selectively reduces the growth of p53-deficient tumor cells. ${ }^{1,9}$ A possible explanation for this discrepancy may lie in the different methodology used: while the current literature is based on RNAi technology used to silence the PIP4K2A protein, our results are based on PIP4K2A kinase inhibition with a small molecule. It is unclear whether PIP4K2A can also act as a scaffolding protein, but it might be hypothesized that complete abrogation of protein function (and not only its kinase) might be required for antitumor activity. In this case, a PROTAC approach, leading to degradation of the whole PIP4K2A protein, would be appropriate to exploit the therapeutic potential of PIP4K2A inhibition in cancer. Interestingly, efforts toward the development of a PIP4K2A/B degrader have been recently reported. ${ }^{10}$ The same source disclosed the discovery of THZ-P1-2 as a covalent inhibitor of PIP4K2A/B/C, which showed moderate antiproliferative activity in acute myeloid leukemia (AML) and acute lymphoblastic leukemia (ALL) cells, including THP-1. These observations are also in stark contrast to our results. However, the authors concluded that the antiproliferative activity of THZ-P1-2 is in part due to its covalency, a factor that might potentially explain the contradictory observations but which requires further elucidation. ${ }^{10}$

\section{- CONCLUSIONS}

We have described here the discovery of potent and highly selective PIP4K2A inhibitors via an HTS lead finding approach. Optimization of HTS hit $\mathbf{1}$ through X-ray-supported medicinal chemistry efforts yielded advanced lead compounds 58 (BAY-297) and 60 (BAY-091). However, inhibition of PIP4K2A with these small molecules does not translate into the hypothesized mode of action and/or antiproliferative activity in p53-deficient tumor cells. CETSA experiments performed in THP-1 cells revealed that both 58 (BAY-297) and 60 (BAY-091) induced a dose-dependent thermal shift, with similar $\mathrm{EC}_{50}$ values, in THP-1 cell lysates as well as intact cells, thereby confirming target engagement in these cellular systems. These results question the viability of PIP4K2A kinase as a therapeutic target for anticancer drug development. Interestingly, a recent study revealed a putative tumorsuppressive role for PIP4K2A in PTEN-deficient glioblasto$\mathrm{ma},{ }^{23}$ suggesting a complex, and possibly context-dependent, biology for this target. Therefore, the availability of potent and selective chemical probes, such as BAY-091 and BAY-297, will significantly contribute to further understanding the biology of PIP4K2A signaling in cancer and/or other diseases and clarify the potential of PIP4K2A as a therapeutic target. Thus, 60 (BAY-091) meets the criteria for chemical probes ${ }^{24,25}$ established by the Structural Genomics Consortium (SGC) ${ }^{26}$ and was accepted by the SGC as a "donated chemical probe" to support open science. The less active enantiomer (data not shown) can be used as a negative control. Once accepted, Bayer probe molecules (soon including PIP4K2A probe BAY$091)^{27-38}$ can be ordered for free via the SGC website. ${ }^{26}$

\section{EXPERIMENTAL SECTION}

Synthetic Procedures. General Methods and Materials. Commercially available reagents and anhydrous solvents were used as supplied without further purification. All air- and moisture-sensitive reactions were carried out in oven-dried (at $120^{\circ} \mathrm{C}$ ) glassware under an inert atmosphere of argon. A Biotage Initiator Classic microwave reactor was used for reactions conducted in a microwave oven. Reactions were monitored by TLC and UPLC analysis with a Waters 
Acquity UPLC-MS Single Quad system; column: Acquity UPLC BEH C18 $1.7 \mu \mathrm{m}, 50 \mathrm{~mm} \times 2.1 \mathrm{~mm}$; basic conditions: eluent A: $\mathrm{H}_{2} \mathrm{O}$ +0.2 vol \% aq $\mathrm{NH}_{3}(32 \%)$, eluent $\mathrm{B}: \mathrm{MeCN}$; gradient: $0-1.6$ min $1-$ $99 \% \mathrm{~B}, 1.6-2.0 \mathrm{~min} 99 \% \mathrm{~B}$; flow: $0.8 \mathrm{~mL} / \mathrm{min}$; acidic conditions: eluent $\mathrm{A}: \mathrm{H}_{2} \mathrm{O}+0.1$ vol \% formic acid (99\%), eluent B: $\mathrm{MeCN}$; gradient: $0-1.6 \min 1-99 \% \mathrm{~B}, 1.6-2.0 \mathrm{~min} 99 \% \mathrm{~B}$; flow: $0.8 \mathrm{~mL} /$ min; temperature: $60{ }^{\circ} \mathrm{C}$; DAD scan: $210-400 \mathrm{~nm}$. Analytical TLC was carried out on aluminum-backed plates coated with Merck Kieselgel $60 \mathrm{~F}_{254}$, with visualization under UV light at $254 \mathrm{~nm}$. Flash chromatography was carried out using a Biotage Isolera One system with 200-400 nm variable detector. Preparative HPLC was carried out with a Waters AutoPurification MS Single Quad system; column: Waters XBridge $\mathrm{C} 185 \mu \mathrm{m}, 100 \mathrm{~mm} \times 30 \mathrm{~mm}$; basic conditions: eluent $\mathrm{A}: \mathrm{H}_{2} \mathrm{O}+0.2$ vol \% aq $\mathrm{NH}_{3}(32 \%)$, eluent $\mathrm{B}: \mathrm{MeCN}$; gradient: $0-0.5 \mathrm{~min} 5 \% \mathrm{~B}$, flow: $25 \mathrm{~mL} / \mathrm{min} ; 0.51-5.50 \mathrm{~min} 10-100 \% \mathrm{~B}$, flow: $70 \mathrm{~mL} / \mathrm{min}$; $5.51-6.5 \mathrm{~min} 100 \% \mathrm{~B}$, flow: $70 \mathrm{~mL} / \mathrm{min}$; acidic conditions: eluent $\mathrm{A}: \mathrm{H}_{2} \mathrm{O}+0.1 \mathrm{vol} \%$ formic acid (99\%), eluent $\mathrm{B}$ : MeCN; gradient: $0-0.5 \mathrm{~min} 5 \% \mathrm{~B}$, flow: $25 \mathrm{~mL} / \mathrm{min}$; $0.51-5.50 \mathrm{~min}$ 10-100\% B, flow: $70 \mathrm{~mL} / \mathrm{min}$; $5.51-6.5 \mathrm{~min} 100 \%$ B, flow: $70 \mathrm{~mL} /$ min; temperature: $25{ }^{\circ} \mathrm{C}$; DAD scan: $210-400 \mathrm{~nm}$. NMR spectra were recorded at $\mathrm{rt}\left(22 \pm 1{ }^{\circ} \mathrm{C}\right)$, unless otherwise noted, on Bruker Avance III HD spectrometers. ${ }^{1} \mathrm{H}$ NMR spectra were obtained at 400 or $500 \mathrm{MHz}$ and referenced to the residual solvent signal $(7.26 \mathrm{ppm}$ for $\mathrm{CDCl}_{3}, 2.50 \mathrm{ppm}$ for DMSO- $\left.d_{6}\right) \cdot{ }^{13} \mathrm{C}$ NMR spectra were obtained at $101 \mathrm{MHz}$ and referenced to the residual solvent signal (39.52 ppm for DMSO- $\left.d_{6}\right) .{ }^{1} \mathrm{H}$ NMR data are reported as follows: chemical shift $(\delta)$ in $\mathrm{ppm}$, multiplicity $(\mathrm{s}=$ singlet, $\mathrm{d}=$ doublet, $\mathrm{t}=$ triplet, $\mathrm{q}=$ quartet, $\mathrm{br}=$ broad, $\mathrm{m}=$ multiplet), integration, and assignment. High-resolution mass spectra were recorded on a Xevo G2-XS Tof (Waters) instrument. Low-resolution mass spectra (electrospray ionization, ESI) were obtained via HPLC-MS (ESI) using a Waters Acquity UPLC system equipped with an SQ 3100 Mass Detector; column: Acquity UPLC BEH C18 $1.7 \mu \mathrm{m}, 50 \mathrm{~mm} \times 2.1 \mathrm{~mm}$; eluent A: $\mathrm{H}_{2} \mathrm{O}+0.05 \%$ formic acid (99\%), eluent B: $\mathrm{MeCN}+0.05 \%$ formic acid (99\%); gradient: $0-0.5 \min 5 \% \mathrm{~B}, 0.5-2.5 \mathrm{~min} 5-100 \% \mathrm{~B}, 2.5-$ $4.5 \mathrm{~min} 100 \% \mathrm{~B}$; total run time: $5 \mathrm{~min}$; flow: $0.5 \mathrm{~mL} / \mathrm{min}$. Optical rotations were recorded on a JASCO P-2000 polarimeter. The purity of all target compounds was at least $95 \%$, as determined by UPLCMS. Compound names were generated using ICS software.

1-[(3-Aminoisonicotinoyl)oxy]pyrrolidine-2,5-dione (5). To a solution of 3-aminopyridine-4-carboxylic acid (3; $50 \mathrm{~g}, 362 \mathrm{mmol}$, commercially available, CAS-RN: [7579-20-6]) in THF (1.42 L) were added 1-ethyl-3-(3-dimethylaminopropyl)carbodiimide hydrochloride (EDC) $(104.09 \mathrm{~g}, 542.99 \mathrm{mmol})$ and DIPEA (107.2 mL, 615.4 $\mathrm{mmol}$ ). The reaction mixture was stirred at $\mathrm{rt}$ for $10 \mathrm{~min}$ and 1 hydroxypyrrolidine-2,5-dione (4; $83.3 \mathrm{~g}, 724.0 \mathrm{mmol}$, commercially available, CAS-RN: [6066-82-6]) was added. The mixture was stirred at rt overnight, filtered over Celite, and the filtrate was concentrated. The residue was partitioned between $\mathrm{H}_{2} \mathrm{O}(250 \mathrm{~mL})$ and EtOAc $(500$ $\mathrm{mL}$ ). The precipitated yellow solid was isolated, treated with $\mathrm{MeCN}$, and filtered. The residue was dried under reduced pressure at $50{ }^{\circ} \mathrm{C}$ overnight to give 5 (91.56 g, quantitative). ${ }^{1} \mathrm{H}$ NMR $(400 \mathrm{MHz}$, DMSO- $\left.d_{6}\right): \delta=8.38(\mathrm{~d}, J=0.76 \mathrm{~Hz}, 1 \mathrm{H}$, pyridine $), 7.81(\mathrm{~d}, J=5.58$ $\mathrm{Hz}, 1 \mathrm{H}$, pyridine $), 7.56(\mathrm{~d}, J=5.34 \mathrm{~Hz}, 1 \mathrm{H}$, pyridine $), 6.96(\mathrm{~s}, 2 \mathrm{H}$, $\left.\mathrm{NH}_{2}\right), 2.82-2.99\left(\mathrm{~m}, 4 \mathrm{H}, \mathrm{CH}_{2}\right)$.

2-(4-Bromophenyl)-4-oxo-1,4-dihydro-1,7-naphthyridine-3-carbonitrile (7). To a suspension of $\mathrm{NaH}(60 \%$ in mineral oil, $21.26 \mathrm{~g}$, $531.5 \mathrm{mmol})$ in THF ( $5 \mathrm{~L})$ was added portion-wise, at rt under argon, 3-(4-bromophenyl)-3-oxopropanenitrile (6; $57.2 \mathrm{~g}, 255.1 \mathrm{mmol})$. The reaction mixture was stirred at rt for $15 \mathrm{~min}$ and $5(50 \mathrm{~g}, 212.6 \mathrm{mmol})$ was added. The mixture was stirred at $70{ }^{\circ} \mathrm{C}$ for $28 \mathrm{~h}$, then cooled to rt. EtOH $(150 \mathrm{~mL})$ was added, the mixture was stirred for $5 \mathrm{~min}$, and the solvent was removed under reduced pressure. $\mathrm{H}_{2} \mathrm{O}(2 \mathrm{~L})$ was added to the residue and the solution was acidified with citric acid. The resulting precipitate was collected by filtration and washed with $\mathrm{H}_{2} \mathrm{O}$. The filter cake was stirred with $\mathrm{MeCN}$, filtered, and washed with hexanes. The crude product was dried under reduced pressure at $50{ }^{\circ} \mathrm{C}$ overnight to yield 7 (59 g, 85\%). ${ }^{1} \mathrm{H}$ NMR (400 MHz, DMSO$\left.d_{6}\right): \delta=9.09(\mathrm{~s}, 1 \mathrm{H}$, pyridine $), 8.56(\mathrm{~d}, J=5.32 \mathrm{~Hz}, 1 \mathrm{H}$, pyridine $)$, $7.94(\mathrm{~d}, J=5.41 \mathrm{~Hz}, 1 \mathrm{H}$, pyridine), 7.83-7.89 (m, 2H, phenyl), 7.71-7.82 (m, 2H, phenyl).

2-(4-Bromophenyl)-4-chloro-1,7-naphthyridine-3-carbonitrile (8a). Compound 7 (3.6 g, $11 \mathrm{mmol})$ was suspended in $\mathrm{POCl}_{3}(33$ $\mathrm{mL}$ ) and heated under reflux for $2 \mathrm{~h}$. $\mathrm{POCl}_{3}$ was evaporated and the resulting residue was partitioned between EtOAc and saturated sodium bicarbonate solution. The aqueous layer was extracted with EtOAc (3x), and the combined organic layers were dried over $\mathrm{Na}_{2} \mathrm{SO}_{4}$. After evaporation of the solvent, the residue was purified by flash column chromatography (silica gel, eluent: hexanes/acetone $0-$ $100 \%$ ) to yield $8 \mathrm{a}(780 \mathrm{mg}, 21 \%) .{ }^{1} \mathrm{H}$ NMR (400 MHz, DMSO- $\left.d_{6}\right)$ : $\delta=9.61(\mathrm{~d}, J=0.76 \mathrm{~Hz}, 1 \mathrm{H}$, pyridine $), 8.91(\mathrm{~d}, J=5.83 \mathrm{~Hz}, 1 \mathrm{H}$, pyridine ), $8.20(\mathrm{dd}, J=0.89,5.70 \mathrm{~Hz}, 1 \mathrm{H}$, pyridine $), 7.68-7.96(\mathrm{~m}$, $4 \mathrm{H}$, phenyl).

4-Bromo-2-(4-bromophenyl)-1,7-naphthyridine-3-carbonitrile (8b). To a solution of $7(2 \mathrm{~g}, 6.13 \mathrm{mmol})$ in DMF $(50 \mathrm{~mL})$ was added $\mathrm{POBr}_{3}(3.5 \mathrm{~g}, 12.26 \mathrm{mmol})$, and the mixture was stirred at $\mathrm{rt}$ for $24 \mathrm{~h}$, then slowly poured into $\mathrm{H}_{2} \mathrm{O}(200 \mathrm{~mL})$. The precipitate was isolated by filtration. The residue was dissolved in DCM, the organic layer was washed with $\mathrm{H}_{2} \mathrm{O}(3 \times)$ and dried over $\mathrm{Na}_{2} \mathrm{SO}_{4}$, and the solvent was removed under reduced pressure. The residue was stirred with $\mathrm{MeCN}$, filtered, and the filter cake was washed with hexanes, then dried under reduced pressure at $50{ }^{\circ} \mathrm{C}$ to yield $8 \mathrm{~b}(1.2 \mathrm{~g}, 50 \%) .{ }^{1} \mathrm{H}$ NMR (400 MHz, DMSO- $\left.d_{6}\right): \delta=9.57(\mathrm{~s}, 1 \mathrm{H}$, pyridine), $8.90(\mathrm{~d}, J=$ $5.83 \mathrm{~Hz}, 1 \mathrm{H}$, pyridine), 8.12 (dd, $J=0.76,5.83 \mathrm{~Hz}, 1 \mathrm{H}$, pyridine), $7.83-7.93(\mathrm{~m}, 4 \mathrm{H}$, phenyl).

tert-Butyl (2R)-2-\{[2-(4-Bromophenyl)-3-cyano-1,7-naphthyridin-4-yl]amino\}butanoate (9). To a solution of $8 \mathbf{b}(2.0 \mathrm{~g}, 5.14$ $\mathrm{mmol})$ in DMF $(100 \mathrm{~mL})$ were added tert-butyl (R)-2-aminobutanoate hydrochloride $(\mathrm{H}-\mathrm{D}-\mathrm{Abu}-\mathrm{O} t-\mathrm{Bu} \cdot \mathrm{HCl})(3.02 \mathrm{~g}, 15.42 \mathrm{mmol}$, commercially available, CAS-RN: [313994-32-0]) and $\mathrm{Et}_{3} \mathrm{~N}(4.3 \mathrm{~mL}$, $30.8 \mathrm{mmol}$ ). The reaction mixture was stirred at $\mathrm{rt}$ overnight and diluted with EtOAc. The mixture was washed with $\mathrm{H}_{2} \mathrm{O}(2 \times)$ and saturated $\mathrm{NaCl}$ solution, dried with $\mathrm{Na}_{2} \mathrm{SO}_{4}$, and the organic solvent was evaporated. The residue was purified by column chromatography (SNAP 50, eluent: $n$-hexane/EtOAc gradient) to yield 9 (2.15 g, $89 \%) .{ }^{1} \mathrm{H}$ NMR (400 MHz, DMSO- $\left.d_{6}\right): \delta=9.25$ (s, $1 \mathrm{H}$, pyridine), $8.69(\mathrm{~d}, J=5.83 \mathrm{~Hz}, 1 \mathrm{H}$, pyridine $), 8.49(\mathrm{~d}, J=5.83 \mathrm{~Hz}, 1 \mathrm{H}$, pyridine), $8.02(\mathrm{~d}, J=8.62 \mathrm{~Hz}, 1 \mathrm{H}, \mathrm{NH}), 7.75$ (br s, $4 \mathrm{H}$, phenyl), 4.94-5.02 (m, $1 \mathrm{H}, \mathrm{CH}-\mathrm{C}(\mathrm{O})), 2.02-2.13\left(\mathrm{~m}, 2 \mathrm{H}, \mathrm{CH}_{2}\right), 1.41(\mathrm{~s}$, $9 \mathrm{H}, t-\mathrm{Bu}), 1.03\left(\mathrm{t}, J=7.35 \mathrm{~Hz}, 3 \mathrm{H}, \mathrm{CH}_{3}\right) . \mathrm{MS}\left(\mathrm{ESI}^{+}\right): m / z=469.2$ $[\mathrm{M}+\mathrm{H}]^{+} .[\alpha]_{\mathrm{D}}^{20}+187.1 \pm 0.56(c=1, \mathrm{DMSO})$.

(2R)-2-\{[2-(4-Bromophenyl)-3-cyano-1,7-naphthyridin-4-yl]amino\}butanoic Acid (10). To a solution of $9(800 \mathrm{mg}, 1.72 \mathrm{mmol})$ in 1,4-dioxane $(10 \mathrm{~mL})$ was added $4 \mathrm{~N} \mathrm{HCl}$ in 1,4-dioxane $(4.3 \mathrm{~mL})$, and the reaction mixture was stirred at $\mathrm{rt}$ for 2 days. The solvent was evaporated, and the residue was crystallized from $\mathrm{H}_{2} \mathrm{O}$ and purified by preparative HPLC (gradient: water 85\%/acetonitrile 15\%-water $45 \% /$ acetonitrile $55 \%$ ) to yield 10 (436 mg, 57\%). LC-MS (basic conditions): ${ }^{t} \mathrm{R}=0.75 \mathrm{~min} . \mathrm{MS}\left(\mathrm{ESI}^{+}\right): m / z=413.4[\mathrm{M}+\mathrm{H}]^{+} .{ }^{1} \mathrm{H}$ NMR (400 MHz, DMSO- $\left.d_{6}\right): \delta=13.16\left(\right.$ br s, $\left.1 \mathrm{H}, \mathrm{CO}_{2} \mathrm{H}\right), 9.25(\mathrm{~s}$, $1 \mathrm{H}$, pyridine), $8.68(\mathrm{~d}, J=5.83 \mathrm{~Hz}, 1 \mathrm{H}$, pyridine), 8.48 (d, $J=5.58$ $\mathrm{Hz}, 1 \mathrm{H}$, pyridine), 8.05 (d, $J=8.87 \mathrm{~Hz}, 1 \mathrm{H}, \mathrm{NH}), 7.74-7.77(\mathrm{~m}, 4 \mathrm{H}$, phenyl), $5.06(\mathrm{dt}, J=4.56,8.74 \mathrm{~Hz}, 1 \mathrm{H}, \mathrm{CH}-\mathrm{C}(\mathrm{O})), 2.00-2.17(\mathrm{~m}$, $\left.2 \mathrm{H}, \mathrm{CH}_{2}\right), 1.03\left(\mathrm{t}, J=7.35 \mathrm{~Hz}, 3 \mathrm{H}, \mathrm{CH}_{3}\right) .[\alpha]_{\mathrm{D}}^{20}+152.7 \pm 0.29(c=1$, DMSO).

(2R)-2-\{[3-Cyano-2-(2'-ethoxybiphenyl-4-yl)-1,7-naphthyridin-4yl]amino\}butanoic Acid (2). A suspension of $10(385 \mathrm{mg}, 0.86 \mathrm{mmol}$ with $92 \%$ purity), (2-ethoxyphenyl)boronic acid $(286 \mathrm{mg}, 1.72 \mathrm{mmol}$, commercially available, CAS-RN: [213211-69-9]), $\mathrm{Pd}\left(\mathrm{PPh}_{3}\right)_{4}$ (99 $\mathrm{mg}, 0.09 \mathrm{mmol})$, and $\mathrm{K}_{2} \mathrm{CO}_{3}(476 \mathrm{mg}, 3.44 \mathrm{mmol})$ in DMF $(9.6 \mathrm{~mL})$ and $\mathrm{H}_{2} \mathrm{O}(1.9 \mathrm{~mL})$ was heated in a microwave oven at $120{ }^{\circ} \mathrm{C}$ for 45 min. The reaction mixture was cooled to rt, diluted with $\mathrm{H}_{2} \mathrm{O}$, acidified with $2 \mathrm{~N}$ aq $\mathrm{HCl}$ to $\mathrm{pH} 4$, and extracted with DCM. The combined organic layers were concentrated under reduced pressure and the residue was purified by flash column chromatography (SNAP 50, eluent: $n$-hexane/EtOAc gradient) to $335 \mathrm{mg}$ of the title compound, which was purified again by preparative HPLC (acidic conditions) to yield $2(60 \mathrm{mg}, 15 \%)$. LC-MS (acidic conditions): ${ }^{t} \mathrm{R}=$ 1.23 min. MS $\left(\mathrm{ESI}^{+}\right): m / z=453.2[\mathrm{M}+\mathrm{H}]^{+} .{ }^{1} \mathrm{H}$ NMR $(400 \mathrm{MHz}$, 
DMSO- $d_{6}$ ): $\delta=13.16$ (br s, $\left.1 \mathrm{H}, \mathrm{CO}_{2} \mathrm{H}\right), 9.26$ (s, $1 \mathrm{H}$, pyridine), 8.68 (d, $J=5.83 \mathrm{~Hz}, 1 \mathrm{H}$, pyridine), $8.49(\mathrm{~d}, J=5.83 \mathrm{~Hz}, 1 \mathrm{H}$, pyridine), $8.00(\mathrm{~d}, J=8.62 \mathrm{~Hz}, 1 \mathrm{H}$, phenyl), 7.82-7.87 ( $\mathrm{m}, 2 \mathrm{H}$, phenyl), 7.66$7.71(\mathrm{~m}, 2 \mathrm{H}$, phenyl), 7.33-7.44 (m, 2H, phenyl, $\mathrm{NH}), 7.14(\mathrm{~d}, J=$ $7.82 \mathrm{~Hz}, 1 \mathrm{H}$, phenyl), $7.06(\mathrm{t}, J=7.18 \mathrm{~Hz}, 1 \mathrm{H}$, phenyl), $5.10(\mathrm{dt}, J=$ $4.56,8.74 \mathrm{~Hz}, 1 \mathrm{H}, \mathrm{CH}-\mathrm{C}(\mathrm{O})), 4.09\left(\mathrm{q}, J=6.84 \mathrm{~Hz}, 2 \mathrm{H}, \mathrm{OCH}_{2}\right)$, 1.99-2.19 (m, $\left.2 \mathrm{H}, \mathrm{CH}_{2}\right), 1.31\left(\mathrm{t}, J=6.84 \mathrm{~Hz}, 3 \mathrm{H}, \mathrm{CH}_{3}\right), 1.05(\mathrm{t}, J=$ $7.35 \mathrm{~Hz}, 3 \mathrm{H}, \mathrm{CH}_{3}$ ). HRMS (ESI, $\left.[\mathrm{M}+\mathrm{H}]^{+}\right)$: calcd for $\mathrm{C}_{27} \mathrm{H}_{25} \mathrm{~N}_{4} \mathrm{O}_{3}$, 453.1927; found, 453.1928. $[\alpha]_{\mathrm{D}}^{20}+125.0 \pm 0.37(c=1$, DMSO).

$\mathrm{N}$-[3-Cyano-2-(2'-ethoxybiphenyl-4-yl)-1,7-naphthyridin-4-yl]alanine (1). Step 1: To a solution of $8 \mathrm{a}(600 \mathrm{mg}, 1.74 \mathrm{mmol})$ in DMF $(50 \mathrm{~mL})$ were added tert-butyl alaninate $(1.01 \mathrm{~g}, 6.96 \mathrm{mmol}$, commercially available, CAS-RN: [69320-88-3]) and $\mathrm{Et}_{3} \mathrm{~N}(1.94 \mathrm{~mL}$, $13.9 \mathrm{mmol}$ ). The reaction mixture was stirred at $\mathrm{rt}$ for $24 \mathrm{~h}$, filtered, and the filtrate was concentrated. The residue was purified by column chromatography (SNAP 50, eluent: $n$-hexane/EtOAc gradient) to yield tert-butyl $N$-[2-(4-bromophenyl)-3-cyano-1,7-naphthyridin-4yl]alaninate $(8 \mathrm{mg}, 1 \%) .{ }^{1} \mathrm{H}$ NMR $\left(400 \mathrm{MHz}, \mathrm{DMSO}-d_{6}\right): \delta=9.24$ (s, $1 \mathrm{H}$, pyridine $), 8.68(\mathrm{~d}, J=5.83 \mathrm{~Hz}, 1 \mathrm{H}$, pyridine $), 8.44(\mathrm{~d}, J=5.83$ $\mathrm{Hz}, 1 \mathrm{H}$, pyridine), 8.15 (d, $J=8.36 \mathrm{~Hz}, 1 \mathrm{H}, \mathrm{NH}), 7.69-7.87(\mathrm{~m}, 4 \mathrm{H}$, phenyl), 5.17-5.25 (m, 1H, CH-C $(\mathrm{O})), 1.64(\mathrm{~d}, J=6.84 \mathrm{~Hz}, 3 \mathrm{H}$, $\left.\mathrm{CH}_{3}\right), 1.41(\mathrm{~s}, 9 \mathrm{H}, t-\mathrm{Bu})$. MS $\left(\mathrm{ESI}^{+}\right): m / z=455.1[\mathrm{M}+\mathrm{H}]^{+}$. Step 2: To a solution of tert-butyl $N$-[2-(4-bromophenyl)-3-cyano-1,7naphthyridin-4-yl]alaninate $(380 \mathrm{mg}, 0.84 \mathrm{mmol})$ in 1,4-dioxane (5 $\mathrm{mL}$ ) was added $4 \mathrm{~N}$ aq $\mathrm{HCl}$, and the reaction mixture was stirred at $\mathrm{rt}$ for 2 days and at $60^{\circ} \mathrm{C}$ for another $4 \mathrm{~h}$. The mixture was cooled to rt, the solvent was evaporated, and the residue was crystallized from $\mathrm{H}_{2} \mathrm{O}$ to yield $N$-[2-(4-bromophenyl)-3-cyano-1,7-naphthyridin-4-yl]alanine (148 mg, 42\%). ${ }^{1} \mathrm{H}$ NMR (400 MHz, DMSO- $d_{6}$ ): $\delta=13.15$ (br s, $\left.1 \mathrm{H}, \mathrm{CO}_{2} \mathrm{H}\right), 9.24(\mathrm{~s}, 1 \mathrm{H}$, pyridine $), 8.67(\mathrm{~d}, J=5.83 \mathrm{~Hz}, 1 \mathrm{H}$, pyridine), $8.43(\mathrm{~d}, J=5.58 \mathrm{~Hz}, 1 \mathrm{H}$, pyridine), $8.17(\mathrm{~d}, J=8.62 \mathrm{~Hz}$, $1 \mathrm{H}, \mathrm{NH}), 7.72-7.80(\mathrm{~m}, 4 \mathrm{H}$, phenyl), 5.23-5.33 (m, 1H, CH$\mathrm{C}(\mathrm{O})), 1.61-1.69\left(\mathrm{~m}, 3 \mathrm{H}, \mathrm{CH}_{3}\right)$. MS $\left(\mathrm{ESI}^{+}\right): m / z=399.3[\mathrm{M}+\mathrm{H}]^{+}$. Step 3: A suspension of $N$-[2-(4-bromophenyl)-3-cyano-1,7-naphthyridin-4-yl]alanine (110 mg, $0.26 \mathrm{mmol}, 94 \%$ purity), (2ethoxyphenyl)boronic acid $(86 \mathrm{mg}, 0.52 \mathrm{mmol}$, commercially available, CAS-RN: [213211-69-9]), $\mathrm{Pd}\left(\mathrm{PPh}_{3}\right)_{4} \quad(30 \mathrm{mg}, 0.026$ $\mathrm{mmol}$ ), and $\mathrm{K}_{2} \mathrm{CO}_{3}(144 \mathrm{mg}, 1.04 \mathrm{mmol})$ in $\mathrm{DMF}(2.9 \mathrm{~mL})$ and $\mathrm{H}_{2} \mathrm{O}(0.58 \mathrm{~mL})$ was heated in a microwave oven at $120{ }^{\circ} \mathrm{C}$ for 45 $\mathrm{min}$. The reaction mixture was cooled to rt, filtered, and the filtrate was acidified with $2 \mathrm{~N}$ aq $\mathrm{HCl}$ to $\mathrm{pH} 4$ and extracted with butanol (3 $\times)$. The combined organic layers were concentrated under reduced pressure, and the residue was purified by HPLC (gradient: water $70 \%$ /acetonitrile $30 \%$-water $30 \%$ /acetonitrile $70 \%$ ) to yield 1 (27 $\mathrm{mg}, 24 \%)$. LC-MS (acidic conditions): ${ }^{t} \mathrm{R}=1.17 \mathrm{~min} . \mathrm{MS}\left(\mathrm{ESI}^{+}\right): \mathrm{m} /$ $z=439.2[\mathrm{M}+\mathrm{H}]^{+} .{ }^{1} \mathrm{H}$ NMR $\left(400 \mathrm{MHz}\right.$, DMSO- $\left.d_{6}\right): \delta=13.15(\mathrm{br}$ s, $\left.1 \mathrm{H}, \mathrm{CO}_{2} \mathrm{H}\right), 9.25(\mathrm{~s}, 1 \mathrm{H}$, pyridine $), 8.67(\mathrm{~d}, J=5.83 \mathrm{~Hz}, 1 \mathrm{H}$, pyridine), $8.43(\mathrm{~d}, J=5.83 \mathrm{~Hz}, 1 \mathrm{H}$, pyridine), $8.13(\mathrm{br} \mathrm{d}, J=8.62 \mathrm{~Hz}$ $1 \mathrm{H}, \mathrm{NH}), 7.84(\mathrm{~d}, J=8.36 \mathrm{~Hz}, 2 \mathrm{H}$, phenyl), $7.68(\mathrm{~d}, J=7.83 \mathrm{~Hz}, 2 \mathrm{H}$, phenyl), $7.28-7.50(\mathrm{~m}, 2 \mathrm{H}$, phenyl), $7.14(\mathrm{~d}, J=8.36 \mathrm{~Hz}, 1 \mathrm{H}$, phenyl), $7.06(\mathrm{t}, J=7.02 \mathrm{~Hz}, 1 \mathrm{H}$, phenyl), 5.25-5.34 (m, 1H, CH$\mathrm{C}(\mathrm{O})), 4.09\left(\mathrm{q}, J=7.10 \mathrm{~Hz}, 2 \mathrm{H}, \mathrm{OCH}_{2}\right), 1.66(\mathrm{~d}, J=7.10 \mathrm{~Hz}, 3 \mathrm{H}$, $\left.\mathrm{CH}_{3}\right), 1.31\left(\mathrm{t}, J=6.97 \mathrm{~Hz}, 3 \mathrm{H}, \mathrm{CH}_{3}\right)$. HRMS $\left(\mathrm{ESI},[\mathrm{M}+\mathrm{H}]^{+}\right)$: calcd for $\mathrm{C}_{26} \mathrm{H}_{23} \mathrm{~N}_{4} \mathrm{O}_{3}, 439.1771$; found, 439.1767 .

(2S)-2-\{[2-(4-Bromophenyl)-3-cyano-1,7-naphthyridin-4-yl]amino\}butanamide (11). Compound 11 (65 mg, 43\%) was prepared analogously to 13 , from $8 \mathbf{b}(140 \mathrm{mg}, 0.36 \mathrm{mmol})$ and (2S)-2aminobutanamide hydrochloride (155 mg, $1.44 \mathrm{mmol}$, 95\% purity, commercially available, CAS-RN: [7682-20-4]). The product was purified by HPLC (gradient: water 70\%/acetonitrile 30\%-water $30 \% /$ acetonitrile $70 \%$ ). LC-MS (acidic conditions): ${ }^{t} \mathrm{R}=1.02 \mathrm{~min}$. MS $\left(\mathrm{ESI}^{+}\right): m / z=410.0[\mathrm{M}+\mathrm{H}]^{+}$. ${ }^{1} \mathrm{H}$ NMR $\left(400 \mathrm{MHz}, \mathrm{DMSO}-d_{6}\right):$ $\delta=9.24(\mathrm{~s}, 1 \mathrm{H}$, pyridine $), 8.67(\mathrm{~d}, J=5.83 \mathrm{~Hz}, 1 \mathrm{H}$, pyridine $), 8.37$ (d, $J=6.08 \mathrm{~Hz}, 1 \mathrm{H}$, pyridine), $7.87(\mathrm{~d}, J=8.36 \mathrm{~Hz}, 1 \mathrm{H}, \mathrm{NH}), 7.71-$ $7.79(\mathrm{~m}, 5 \mathrm{H}$, phenyl, NH), $7.40(\mathrm{~s}, 1 \mathrm{H}, \mathrm{NH}), 4.96(\mathrm{dt}, J=4.82,8.11$ $\mathrm{Hz}, 1 \mathrm{H}, \mathrm{CH}-\mathrm{C}(\mathrm{O})), 1.95-2.16\left(\mathrm{~m}, 2 \mathrm{H}, \mathrm{CH}_{2}\right), 0.94(\mathrm{t}, J=7.22 \mathrm{~Hz}$, $\left.3 \mathrm{H}, \mathrm{CH}_{3}\right)$. HRMS (ESI, $\left.[\mathrm{M}+\mathrm{H}]^{+}\right)$: calcd for $\mathrm{C}_{19} \mathrm{H}_{17} \mathrm{BrN}_{5} \mathrm{O}$, 410.0617; found, 410.0612. $[\alpha]_{\mathrm{D}}^{20}-12.4 \pm 0.62(c=1$, DMSO $)$. chiral HPLC: column: cellulose SC, $50 \times 3.6 \mathrm{~mm}, 3 \mu \mathrm{m}$, solvent: $20-50 \%$ $\mathrm{EtOH} /$ hexane, buffer: 0.1\% DEA, ${ }^{t} \mathrm{R}=1.42 \mathrm{~min}, 99.2 \%$.
(2R)-2-\{[2-(4-Bromophenyl)-3-cyano-1,7-naphthyridin-4-yl]amino\}butanamide (12). Compound $12(2.9 \mathrm{~g}, 96 \%)$ was prepared analogously to 13 , from $8 \mathbf{b}(2.85 \mathrm{~g}, 7.31 \mathrm{mmol})$ and $(2 R)-2$ aminobutanamide hydrochloride $(3.2 \mathrm{~g}, 21.93 \mathrm{mmol}$, 95\% purity, commercially available, CAS-RN: [103765-03-3]). LC-MS (acidic conditions): ${ }^{t} \mathrm{R}=1.04 \min$. MS $\left(\mathrm{ESI}^{+}\right): m / z=412.0[\mathrm{M}+\mathrm{H}]^{+} .{ }^{1} \mathrm{H}$ NMR (400 MHz, DMSO- $\left.d_{6}\right): \delta=9.24(\mathrm{~s}, 1 \mathrm{H}$, pyridine), 8.67 (d, $J=$ $5.83 \mathrm{~Hz}, 1 \mathrm{H}$, pyridine $), 8.36(\mathrm{~d}, J=5.83 \mathrm{~Hz}, 1 \mathrm{H}$, pyridine), $7.87(\mathrm{~d}, J$ $=8.62 \mathrm{~Hz}, 1 \mathrm{H}, \mathrm{NH}), 7.71-7.80(\mathrm{~m}, 5 \mathrm{H}$, phenyl, $\mathrm{NH}), 7.40(\mathrm{~s}, 1 \mathrm{H}$, $\mathrm{NH}), 4.96(\mathrm{dt}, J=4.56,8.11 \mathrm{~Hz}, 1 \mathrm{H}, \mathrm{CH}-\mathrm{C}(\mathrm{O})), 1.95-2.16(\mathrm{~m}, 2 \mathrm{H}$, $\left.\mathrm{CH}_{2}\right), 0.94\left(\mathrm{t}, J=7.35 \mathrm{~Hz}, 3 \mathrm{H}, \mathrm{CH}_{3}\right)$. HRMS (ESI, $\left.[\mathrm{M}+\mathrm{H}]^{+}\right)$: calcd for $\mathrm{C}_{19} \mathrm{H}_{17} \mathrm{BrN}_{5} \mathrm{O}$, 410.0617; found, 410.0617. $[\alpha]_{\mathrm{D}}^{20}+44.4 \pm 0.74(c$ $=1$, DMSO). chiral HPLC: column: cellulose SC, $50 \mathrm{~mm} \times 3.6 \mathrm{~mm}, 3$ $\mu \mathrm{m}$, solvent: $20-50 \% \mathrm{EtOH} /$ hexane, buffer: $0.1 \% \mathrm{DEA},{ }^{t} \mathrm{R}=1.27$ min, $96.9 \%$.

$N^{2}$-[2-(4-Bromophenyl)-3-cyano-1,7-naphthyridin-4-yl]alaninamide (13). To a solution of $8 \mathbf{b}(140 \mathrm{mg}, 0.338 \mathrm{mmol}, 94 \%$ purity) in DMF $(3 \mathrm{~mL})$ were added DL-alaninamide $(125.5 \mathrm{mg}, 1.35$ mmol, 95\% purity, commercially available, CAS-RN: [4726-84-5]) and $\mathrm{Et}_{3} \mathrm{~N}(0.38 \mathrm{~mL}, 2.7 \mathrm{mmol})$. The reaction mixture was stirred at $\mathrm{rt}$ for $24 \mathrm{~h}$, poured into $\mathrm{H}_{2} \mathrm{O}$, and the precipitate was collected by filtration. Recrystallization from cyclopentyl methyl ether gave 13 (67 $\mathrm{mg}, 48 \%)$. LC-MS (acidic conditions): ${ }^{t} \mathrm{R}=0.96 \mathrm{~min} . \mathrm{MS}\left(\mathrm{ESI}^{+}\right): \mathrm{m} /$ $z=398.0[\mathrm{M}+\mathrm{H}]^{+} .{ }^{1} \mathrm{H}$ NMR $\left(400 \mathrm{MHz}, \mathrm{DMSO}-d_{6}\right): \delta=9.23(\mathrm{~s}$, $1 \mathrm{H}$, pyridine), 8.66 (d, $J=5.83 \mathrm{~Hz}, 1 \mathrm{H}$, pyridine), 8.33 (d, $J=5.83$ $\mathrm{Hz}, 1 \mathrm{H}$, pyridine $), 8.00(\mathrm{~d}, J=8.11 \mathrm{~Hz}, 1 \mathrm{H}, \mathrm{NH}), 7.67-7.80(\mathrm{~m}, 5 \mathrm{H}$, phenyl, NH), 7.37 (s, 1H, NH), 5.06-5.15 (m, 1H, CH-C(O)), 1.60 $\left(\mathrm{d}, J=6.84 \mathrm{~Hz}, 3 \mathrm{H}, \mathrm{CH}_{3}\right)$. HRMS (ESI, $\left.[\mathrm{M}+\mathrm{H}]^{+}\right)$: calcd for $\mathrm{C}_{18} \mathrm{H}_{15} \mathrm{BrN}_{5} \mathrm{O}$, 396.0461; found, 396.0461 .

$N^{2}$-[2-(4-Bromophenyl)-3-cyano-1,7-naphthyridin-4-yl]glycinamide (14). Compound $14(44 \mathrm{mg}, 34 \%)$ was prepared analogously to 13 , from $\mathbf{8 b}(140 \mathrm{mg}, 0.34 \mathrm{mmol}, 94 \%$ purity) and glycinamide hydrochloride (157 mg, $1.35 \mathrm{mmol}$, 95\% purity, commercially available, CAS-RN: [1668-10-6]). LC-MS (acidic conditions): ${ }^{t} \mathrm{R}=0.90 \mathrm{~min}$. MS $\left(\mathrm{ESI}^{+}\right): \mathrm{m} / z=382.2[\mathrm{M}+\mathrm{H}]^{+} .{ }^{1} \mathrm{H}$ NMR (400 MHz, DMSO- $\left.d_{6}\right): \delta=9.22(\mathrm{~s}, 1 \mathrm{H}$, pyridine), $8.65(\mathrm{~d}, J=$ $5.83 \mathrm{~Hz}, 1 \mathrm{H}$, pyridine), $8.46(\mathrm{t}, J=6.46 \mathrm{~Hz}, 1 \mathrm{H}, \mathrm{NH}), 8.18(\mathrm{~d}, J=$ $5.58 \mathrm{~Hz}, 1 \mathrm{H}$, pyridine), 7.65-7.77 (m, $5 \mathrm{H}$, phenyl, $\mathrm{NH}), 7.29(\mathrm{~s}, 1 \mathrm{H}$, $\mathrm{NH}), 4.46\left(\mathrm{~d}, J=6.34 \mathrm{~Hz}, 2 \mathrm{H}, \mathrm{CH}_{2}\right)$. HRMS $\left(\mathrm{ESI},[\mathrm{M}+\mathrm{H}]^{+}\right)$: calcd for $\mathrm{C}_{17} \mathrm{H}_{13} \mathrm{BrN}_{5} \mathrm{O}$, 382.0304; found, 382.0306.

$N^{2}$-[2-(4-Bromophenyl)-3-cyano-1,7-naphthyridin-4-yl]- $N^{2}$. methylglycinamide (15). Compound $\mathbf{1 5}(95 \mathrm{mg}, 70 \%)$ was prepared analogously to 13 , from $8 \mathbf{b}\left(140 \mathrm{mg}, 0.34 \mathrm{mmol}, 94 \%\right.$ purity) and $\mathrm{N}^{2}$ methylglycinamide hydrochloride $(177 \mathrm{mg}, 1.35 \mathrm{mmol}, 95 \%$ purity, commercially available, CAS-RN: [5325-64-4]). LC-MS (acidic conditions): ${ }^{t} \mathrm{R}=0.98 \mathrm{~min}$. MS $\left(\mathrm{ESI}^{+}\right): \mathrm{m} / z=398.2[\mathrm{M}+\mathrm{H}]^{+} .{ }^{1} \mathrm{H}$ NMR (400 MHz, DMSO- $\left.d_{6}\right): \delta=9.34(\mathrm{~s}, 1 \mathrm{H}$, pyridine), $8.62(\mathrm{~d}, J=$ $5.83 \mathrm{~Hz}, 1 \mathrm{H}$, pyridine $), 8.12(\mathrm{~d}, J=6.59 \mathrm{~Hz}, 1 \mathrm{H}$, pyridine), $7.76-7.88$ (m, 4H, phenyl), $7.69(\mathrm{~s}, 1 \mathrm{H}, \mathrm{NH}), 7.33(\mathrm{~s}, 1 \mathrm{H}, \mathrm{NH}), 4.33(\mathrm{~s}, 2 \mathrm{H}$, $\left.\mathrm{CH}_{2}\right), 3.41\left(\mathrm{~s}, 3 \mathrm{H}, \mathrm{CH}_{3}\right)$. HRMS (ESI, $\left.[\mathrm{M}+\mathrm{H}]^{+}\right)$: calcd for $\mathrm{C}_{18} \mathrm{H}_{15} \mathrm{BrN}_{5} \mathrm{O}$, 396.0461; found, 396.0458 .

$N^{2}$-[2-(4-Bromophenyl)-3-cyano-1,7-naphthyridin-4-yl]-2-methylalaninamide (16). Compound $16(8 \mathrm{mg}, 6 \%)$ was prepared analogously to 13 , from $8 \mathbf{b}(140 \mathrm{mg}, 0.34 \mathrm{mmol}, 94 \%$ purity) and 2methylalaninamide $(138 \mathrm{mg}, 1.35 \mathrm{mmol}$, commercially available, CAS-RN: [16252-90-7]). The product was purified by HPLC (gradient: water $85 \%$ /acetonitrile $15 \%$-water $45 \%$ /acetonitrile $55 \%)$. LC-MS (acidic conditions): ${ }^{t} \mathrm{R}=0.96 \mathrm{~min} . \mathrm{MS}\left(\mathrm{ESI}^{+}\right): \mathrm{m} / z$ $=412.3[\mathrm{M}+\mathrm{H}]^{+} .{ }^{1} \mathrm{H}$ NMR $\left(400 \mathrm{MHz}\right.$, DMSO- $\left.d_{6}\right): \delta=9.23(\mathrm{~s}, 1 \mathrm{H}$, pyridine), 8.66 (br s, $1 \mathrm{H}$, pyridine), 8.28 (br s, $1 \mathrm{H}$, pyridine), 7.707.74 (br m, 5H, phenyl, NH), $7.55\left(\mathrm{~s}, 1 \mathrm{H}, \mathrm{CONH}_{2}\right), 7.35(\mathrm{~s}, 1 \mathrm{H}$, $\left.\mathrm{CONH}_{2}\right), 1.76\left(\mathrm{~s}, 6 \mathrm{H}, \mathrm{CH}_{3}\right)$.

(2R)-2-\{[3-Cyano-2-(2'-ethoxybiphenyl-4-yl)-1,7-naphthyridin-4yl]amino\}butanamide (17). A suspension of $12(130 \mathrm{mg}, 0.32$ $\mathrm{mmol}$ ), (2-ethoxyphenyl)boronic acid (79 $\mathrm{mg}, 0.48 \mathrm{mmol}$, commercially available, CAS-RN: [213211-69-9]), 2nd generation XPhos pre-catalyst (XPhos Pd G2; $50 \mathrm{mg}, 0.063 \mathrm{mmol}$ ), and $0.5 \mathrm{M}$ aq potassium phosphate $(1.90 \mathrm{~mL}, 0.95 \mathrm{mmol})$ in THF $(4 \mathrm{~mL})$ was stirred at $\mathrm{rt}$ for $16 \mathrm{~h}$. The reaction mixture was poured into $\mathrm{H}_{2} \mathrm{O}$, and the precipitate was collected and purified by HPLC (gradient: water 
$70 \%$ /acetonitrile $30 \%$-water $30 \%$ /acetonitrile $70 \%$ ) to yield $\mathbf{1 7}$ (54 $\mathrm{mg}, 38 \%)$. LC-MS (acidic conditions): ${ }^{t} \mathrm{R}=1.23 \mathrm{~min} . \mathrm{MS}\left(\mathrm{ESI}^{+}\right): \mathrm{m} /$ $z=452.9[\mathrm{M}+\mathrm{H}]^{+} .{ }^{1} \mathrm{H}$ NMR $\left(400 \mathrm{MHz}, \mathrm{DMSO}-d_{6}\right): \delta=9.25(\mathrm{~s}$, $1 \mathrm{H}$, pyridine), 8.67 (d, $J=5.83 \mathrm{~Hz}, 1 \mathrm{H}$, pyridine), 8.37 (d, $J=5.58$ $\mathrm{Hz}, 1 \mathrm{H}$, pyridine), 7.78-7.86 (m, 4H, phenyl, $\mathrm{NH}), 7.69$ (d, $J=7.27$ $\mathrm{Hz}, 2 \mathrm{H}$, phenyl), 7.34-7.44 (m, 3H, phenyl, NH), 7.14 (d, $J=8.44$ $\mathrm{Hz}, 1 \mathrm{H}$, phenyl), $7.07(\mathrm{t}, J=7.43 \mathrm{~Hz}, 1 \mathrm{H}$, phenyl), $5.00(\mathrm{dt}, J=4.82$, $8.11 \mathrm{~Hz}, 1 \mathrm{H}, \mathrm{CH}-\mathrm{C}(\mathrm{O})), 4.09\left(\mathrm{q}, J=6.84 \mathrm{~Hz}, 2 \mathrm{H}, \mathrm{OCH}_{2}\right), 1.96-$ $2.17\left(\mathrm{~m}, 2 \mathrm{H}, \mathrm{CH}_{2}\right), 1.31\left(\mathrm{t}, J=6.84 \mathrm{~Hz}, 3 \mathrm{H}, \mathrm{CH}_{3}\right), 0.96(\mathrm{t}, J=7.35$ $\mathrm{Hz}, 3 \mathrm{H}, \mathrm{CH}_{3}$ ). HRMS (ESI, $\left.[\mathrm{M}+\mathrm{H}]^{+}\right)$: calcd for $\mathrm{C}_{27} \mathrm{H}_{26} \mathrm{~N}_{5} \mathrm{O}_{2}$, 452.2087; found, 452.2087. $[\alpha]_{\mathrm{D}}^{20}+39.9 \pm 0.17(c=1$, DMSO).

$N^{2}$-[3-Cyano-2-(2'-ethoxybiphenyl-4-yl)-1,7-naphthyridin-4-yl]norleucinamide (18). Step 1: $N^{2}$-[2-(4-Bromophenyl)-3-cyano-1,7naphthyridin-4-yl]norleucinamide was prepared analogously to 13, from $8 \mathbf{b}$ ( $88 \%$ purity, $100 \mathrm{mg}, 0.23 \mathrm{mmol}$ ) and DL-norleucinamide ( 88 $\mathrm{mg}, 0.68 \mathrm{mmol}$, commercially available, CAS-RN: [44805-21-2]). The crude reaction product $(150 \mathrm{mg})$ was used without further purification in the next step. Step 2: Compound 18 (62 mg, 56\% over 2 steps) was prepared analogously to 17 , from $150 \mathrm{mg}$ crude $N^{2}$. [2-(4-bromophenyl)-3-cyano-1,7-naphthyridin-4-yl]norleucinamide and (2-ethoxyphenyl)boronic acid $(85 \mathrm{mg}, 0.51 \mathrm{mmol}$, commercially available, CAS-RN: [213211-69-9]). LC-MS (acidic conditions): ${ }^{t} \mathrm{R}=$ $1.35 \mathrm{~min}$. MS $\left(\mathrm{ESI}^{+}\right): m / z=480.9[\mathrm{M}+\mathrm{H}]^{+} .{ }^{1} \mathrm{H}$ NMR $(400 \mathrm{MHz}$, DMSO- $\left.d_{6}\right): \delta=9.25(\mathrm{~s}, 1 \mathrm{H}$, pyridine $), 8.67(\mathrm{~d}, J=5.83 \mathrm{~Hz}, 1 \mathrm{H}$, pyridine), $8.39(\mathrm{~d}, J=5.58 \mathrm{~Hz}, 1 \mathrm{H}$, pyridine $), 7.80-7.87(\mathrm{~m}, 3 \mathrm{H}$, phenyl, NH), $7.76(\mathrm{~s}, 1 \mathrm{H}, \mathrm{NH}), 7.66-7.71(\mathrm{~m}, 2 \mathrm{H}$, phenyl), 7.34$7.43(\mathrm{~m}, 3 \mathrm{H}$, phenyl, NH), 7.14 (dd, $J=8.36,0.76 \mathrm{~Hz}, 1 \mathrm{H}$, phenyl), $7.06(\mathrm{td}, J=7.48,1.01 \mathrm{~Hz}, 1 \mathrm{H}$, phenyl), 5.00-5.09 (m, $1 \mathrm{H}, \mathrm{CH}-$ $\mathrm{C}(\mathrm{O})), 4.09\left(\mathrm{q}, J=6.84 \mathrm{~Hz}, 2 \mathrm{H}, \mathrm{OCH}_{2}\right), 1.95-2.13\left(\mathrm{~m}, 2 \mathrm{H}, \mathrm{CH}_{2}\right)$, $1.28-1.42\left(\mathrm{~m}, 7 \mathrm{H}, \mathrm{CH}_{3}, \mathrm{CH}_{2}\right), 0.86\left(\mathrm{t}, J=6.85 \mathrm{~Hz}, 3 \mathrm{H}, \mathrm{CH}_{3}\right)$.

2-\{[3-Cyano-2-(2'-ethoxybiphenyl-4-yl)-1,7-naphthyridin-4-yl]amino\}-2-cyclopropylethanamide (19). Step 1: A solution of 7 (7.35 g, $22.54 \mathrm{mmol}$ ), (2-ethoxyphenyl)boronic acid (4.676 g, 28.17 $\mathrm{mmol}), \mathrm{PdCl}_{2}(\mathrm{dppf}) \mathrm{DCM}$ complex $(3.678 \mathrm{~g}, 4.51 \mathrm{mmol})$, and $2 \mathrm{M}$ aq $\mathrm{K}_{2} \mathrm{CO}_{3}$ solution $(56.34 \mathrm{~mL}, 112.68 \mathrm{mmol})$ in THF $(700 \mathrm{~mL})$ was stirred at $60{ }^{\circ} \mathrm{C}$ for 3 days. The organic solvent was removed under reduced pressure, and the remaining aqueous layer was extracted with DCM $(3 \times)$. The combined organic layers were dried over $\mathrm{Na}_{2} \mathrm{SO}_{4}$, and the solvent was removed under reduced pressure. The residue was purified by flash column chromatography ( $n$-hexane/EtOAc gradient) to yield 2-(2'-ethoxybiphenyl-4-yl)-4-oxo-1,4-dihydro-1,7naphthyridine-3-carbonitrile (8.0 g, 96\%). ${ }^{1} \mathrm{H}$ NMR (400 MHz, DMSO-d $\left.d_{6}\right): \delta=13.16(\mathrm{~s}, 1 \mathrm{H}, \mathrm{OH}), 9.17(\mathrm{~s}, 1 \mathrm{H}$, pyridine), 8.65 (d, $J$ $=5.32 \mathrm{~Hz}, 1 \mathrm{H}$, pyridine $), 8.00(\mathrm{dd}, J=0.76,5.32 \mathrm{~Hz}, 1 \mathrm{H}$, pyridine $)$, 7.80-7.89 (m, 4H, phenyl), 7.37-7.44 (m, 2H, phenyl), $7.17(\mathrm{~d}, J=$ $8.11 \mathrm{~Hz}, 1 \mathrm{H}$, phenyl), $7.08(\mathrm{dt}, J=1.01,7.48 \mathrm{~Hz}, 1 \mathrm{H}$, phenyl), 4.12 $\left(\mathrm{q}, J=6.84 \mathrm{~Hz}, 2 \mathrm{H}, \mathrm{CH}_{2}\right), 1.31\left(\mathrm{t}, J=6.97 \mathrm{~Hz}, 3 \mathrm{H}, \mathrm{CH}_{3}\right) . \mathrm{MS}$ $\left(\mathrm{ESI}^{+}\right): m / z=368.1[\mathrm{M}+\mathrm{H}]^{+}$. Step 2: A mixture of $2-\left(2^{\prime}-\right.$ ethoxybiphenyl-4-yl)-4-oxo-1,4-dihydro-1,7-naphthyridine-3-carbonitrile $(15 \mathrm{~g}, 40.83 \mathrm{mmol})$ and $\mathrm{POBr}_{3}(23.41 \mathrm{~g}, 81.68 \mathrm{mmol})$ in DMF $(3.56 \mathrm{~L})$ was stirred at $\mathrm{rt}$ for $3 \mathrm{~h}$. The reaction mixture was slowly poured into ice-water, and the resulting precipitate was isolated by filtration and dried under reduced pressure at $70{ }^{\circ} \mathrm{C}$ to give crude 4bromo-2-(2'-ethoxybiphenyl-4-yl)-1,7-naphthyridine-3-carbonitrile $(16 \mathrm{~g})$. MS $\left(\mathrm{ESI}^{+}\right): \mathrm{m} / z=432.0[\mathrm{M}+\mathrm{H}]^{+}$. The crude material was used without further purification in the next step. Step 3: A mixture of crude 4-bromo-2-(2'-ethoxybiphenyl-4-yl)-1,7-naphthyridine-3-carbonitrile (200 mg, $0.418 \mathrm{mmol}$, 90\% purity), ethyl amino(cyclopropyl)acetate hydrochloride $(150 \mathrm{mg}, 0.837 \mathrm{mmol}$, commercially available, CAS-RN: [1311313-77-5]), and $\mathrm{Et}_{3} \mathrm{~N}(0.466 \mathrm{~mL}, 3.35$ $\mathrm{mmol})$ in $\mathrm{MeCN}(0.35 \mathrm{~mL})$ was stirred at $50{ }^{\circ} \mathrm{C}$ for 2 days. The solvent was removed under reduced pressure and the residue was purified by flash column chromatography (gradient: $n$-hexane/ EtOAc) to yield ethyl $\{[3$-cyano-2-(2'-ethoxybiphenyl-4-yl)-1,7naphthyridin-4-yl]amino\} (cyclopropyl)acetate $(77 \mathrm{mg}, 38 \%) .{ }^{1} \mathrm{H}$ NMR (400 MHz, DMSO- $\left.d_{6}\right): \delta=9.26(\mathrm{~s}, 1 \mathrm{H}$, pyridine), 8.69 (d, $J$ $=5.83 \mathrm{~Hz}, 1 \mathrm{H}$, pyridine $), 8.54(\mathrm{~d}, J=5.58 \mathrm{~Hz}, 1 \mathrm{H}$, pyridine $), 8.31(\mathrm{~d}$, $J=8.36 \mathrm{~Hz}, 1 \mathrm{H}, \mathrm{NH}), 7.81-7.87(\mathrm{~m}, 2 \mathrm{H}$, phenyl), 7.61-7.74 (m, $2 \mathrm{H}$, phenyl), $7.33-7.42(\mathrm{~m}, 2 \mathrm{H}$, phenyl), $7.14(\mathrm{~d}, J=7.65 \mathrm{~Hz}, 1 \mathrm{H}$, phenyl), $7.06(\mathrm{t}, J=7.41 \mathrm{~Hz}, 1 \mathrm{H}$, phenyl), $4.51(\mathrm{t}, J=8.74 \mathrm{~Hz}, 1 \mathrm{H}$,
$\mathrm{CH}-\mathrm{C}(\mathrm{O})), 4.00-4.25\left(\mathrm{~m}, 4 \mathrm{H}, \mathrm{OCH}_{2}\right), 1.41-1.68(\mathrm{~m}, 1 \mathrm{H}$, cyclopropyl $), 1.13-1.36\left(\mathrm{~m}, 6 \mathrm{H}, \mathrm{CH}_{3}\right), 0.74-0.92(\mathrm{~m}, 2 \mathrm{H}$, cyclopropyl), $0.52-0.71(\mathrm{~m}, 2 \mathrm{H}$, cyclopropyl). Step 4: To a solution of ethyl \{[3-cyano-2-(2'-ethoxybiphenyl-4-yl)-1,7-naphthyridin-4-yl]amino\} (cyclopropyl)acetate $(77 \mathrm{mg}, 0.156 \mathrm{mmol}$ ) in 1,4-dioxane (1 $\mathrm{mL}$ ) was added $0.367 \mathrm{M}$ aq $\mathrm{LiOH}(0.9 \mathrm{~mL}, 0.34 \mathrm{mmol})$, and the reaction mixture was stirred at $\mathrm{rt}$ for 5 days. Then, the $\mathrm{pH}$ was adjusted to 5 by addition of $2 \mathrm{M}$ aq $\mathrm{HCl}$. Dilution with $\mathrm{H}_{2} \mathrm{O}$, extraction with EtOAc $(3 \times)$, and drying of the combined organic layers over $\mathrm{Na}_{2} \mathrm{SO}_{4}$ gave $\{[3$-cyano-2-(2'-ethoxybiphenyl-4-yl)-1,7naphthyridin-4-yl]amino $\}$ (cyclopropyl)acetic acid (15 mg, $21 \%) .{ }^{1} \mathrm{H}$ NMR $\left(400 \mathrm{MHz}\right.$, DMSO- $\left.d_{6}\right): \delta=9.22(\mathrm{~s}, 1 \mathrm{H}$, pyridine), 8.65 (d, $J=$ $5.58 \mathrm{~Hz}, 1 \mathrm{H}$, pyridine), 8.37 (br s, $1 \mathrm{H}$, pyridine), 8.25 (br s, $1 \mathrm{H}$, $\mathrm{NH}), 7.82(\mathrm{~d}, J=8.36 \mathrm{~Hz}, 2 \mathrm{H}$, phenyl), $7.67(\mathrm{~d}, J=8.36 \mathrm{~Hz}, 2 \mathrm{H}$, phenyl), 7.34-7.43 (m, $2 \mathrm{H}$, phenyl), 7.04-7.17 (m, $2 \mathrm{H}$, phenyl), $4.62(\mathrm{br} \mathrm{t}, J=6.72 \mathrm{~Hz}, 1 \mathrm{H}, \mathrm{CH}-\mathrm{C}(\mathrm{O})), 4.06-4.13\left(\mathrm{~m}, 2 \mathrm{H}, \mathrm{OCH}_{2}\right)$, $1.39-1.55\left(\mathrm{~m}, 1 \mathrm{H}\right.$, cyclopropyl), $1.23-1.36\left(\mathrm{~m}, 3 \mathrm{H}, \mathrm{CH}_{3}\right), 0.57(\mathrm{br}$ $\mathrm{d}, J=3.55 \mathrm{~Hz}, 2 \mathrm{H}$, cyclopropyl), 0.47 (m, $2 \mathrm{H}$, cyclopropyl). MS $\left(\mathrm{ESI}^{+}\right): m / z=465.2[\mathrm{M}+\mathrm{H}]^{+}$. Step 5: Compound $19(40 \mathrm{mg}, 52 \%)$ was prepared analogously to 23 , from $\{[3$-cyano-2-(2'-ethoxybiphenyl-4-yl)-1,7-naphthyridin-4-yl] amino $\}$ (cyclopropyl)acetic acid (72 $\mathrm{mg}, 0.156 \mathrm{mmol})$ and ammonium chloride $(41 \mathrm{mg}, 0.781 \mathrm{mmol})$. DMF was used instead of THF as the solvent. LC-MS (acidic conditions): ${ }^{t} \mathrm{R}=1.23 \mathrm{~min}$. MS $\left(\mathrm{ESI}^{+}\right): \mathrm{m} / z=464.5[\mathrm{M}+\mathrm{H}]^{+} .{ }^{1} \mathrm{H}$ NMR (400 MHz, DMSO- $\left.d_{6}\right): \delta=9.25(\mathrm{~s}, 1 \mathrm{H}$, pyridine), 8.67 (d, $J=$ $5.83 \mathrm{~Hz}, 1 \mathrm{H}$, pyridine ), $8.40(\mathrm{~d}, J=5.58 \mathrm{~Hz}, 1 \mathrm{H}$, pyridine $), 7.80-7.91$ $(\mathrm{m}, 3 \mathrm{H}$, phenyl, $\mathrm{NH}), 7.62-7.72(\mathrm{~m}, 3 \mathrm{H}$, phenyl, $\mathrm{NH}), 7.33-7.46$ (m, 3H, phenyl, NH), $7.14(\mathrm{~d}, J=7.76 \mathrm{~Hz}, 1 \mathrm{H}$, phenyl), $7.06(\mathrm{t}, J=$ $7.37 \mathrm{~Hz}, 1 \mathrm{H}$, phenyl), $4.60(\mathrm{t}, J=8.11 \mathrm{~Hz}, 1 \mathrm{H}, \mathrm{CH}-\mathrm{C}(\mathrm{O})), 4.00-4.12$ $\left(\mathrm{m}, 2 \mathrm{H}, \mathrm{OCH}_{2}\right), 1.40-1.60(\mathrm{~m}, 1 \mathrm{H}$, cyclopropyl $), 1.31(\mathrm{t}, J=6.97$ $\left.\mathrm{Hz}, 3 \mathrm{H}, \mathrm{CH}_{3}\right), 0.61-0.79$ (m, $2 \mathrm{H}$, cyclopropyl), 0.49-0.59 (m, $2 \mathrm{H}$, cyclopropyl). HRMS (ESI, $\left.[\mathrm{M}+\mathrm{H}]^{+}\right)$: calcd for $\mathrm{C}_{28} \mathrm{H}_{26} \mathrm{~N}_{5} \mathrm{O}_{2}$, 464.2087; found, 464.2091.

$N^{2}$-[3-Cyano-2-(2'-ethoxybiphenyl-4-yl)-1,7-naphthyridin-4-yl]D-leucinamide (20). Step 1: $N^{2}$-[2-(4-Bromophenyl)-3-cyano-1,7naphthyridin-4-yl]-D-leucinamide (99 $\mathrm{mg}$, quantitative) was prepared analogously to 13 , from $8 \mathbf{b}(100 \mathrm{mg}, 0.23 \mathrm{mmol}, 88 \%$ purity) and Dleucinamide ( $88 \mathrm{mg}, 0.679 \mathrm{mmol}$, commercially available, CAS-RN: [15893-47-7]). MS $\left(\mathrm{ESI}^{+}\right): m / z=439.3[\mathrm{M}+\mathrm{H}]^{+}$. The crude compound was directly used in the next step. Step 2: Compound 20 $(25 \mathrm{mg}, 14 \%)$ was prepared analogously to 17 , from $N^{2}$-[2-(4bromophenyl)-3-cyano-1,7-naphthyridin-4-yl]-D-leucinamide (150 $\mathrm{mg}, 0.342 \mathrm{mmol}$ ) and (2-ethoxyphenyl)boronic acid $(85 \mathrm{mg}, 0.513$ mmol, commercially available, CAS-RN: [213211-69-9]). LC-MS (acidic conditions): ${ }^{t} \mathrm{R}=1.33 \mathrm{~min}$. MS $\left(\mathrm{ESI}^{+}\right): \mathrm{m} / z=480.7[\mathrm{M}+$ $\mathrm{H}]^{+}$. ${ }^{1} \mathrm{H}$ NMR (400 MHz, DMSO- $d_{6}$ ): $\delta=9.24$ (s, $1 \mathrm{H}$, pyridine), $8.66(\mathrm{~d}, J=5.83 \mathrm{~Hz}, 1 \mathrm{H}$, pyridine $), 8.49(\mathrm{~d}, J=5.32 \mathrm{~Hz}, 1 \mathrm{H}$, pyridine $), 7.88(\mathrm{~d}, J=9.12 \mathrm{~Hz}, 1 \mathrm{H}$, phenyl), $7.78-7.83(\mathrm{~m}, 2 \mathrm{H}$, phenyl), 7.66-7.72 (m, 3H, phenyl, NH), 7.34-7.49 (m, 2H, phenyl, $\mathrm{NH}), 7.29(\mathrm{~s}, 1 \mathrm{H}, \mathrm{NH}), 7.14(\mathrm{~d}, J=8.30 \mathrm{~Hz}, 1 \mathrm{H}$, phenyl), $7.06(\mathrm{t}, J=$ $7.18 \mathrm{~Hz}, 1 \mathrm{H}$, phenyl), 5.07-5.14 (m, 1H, CH-C $(\mathrm{O})), 4.09$ (q, $J=$ $\left.7.10 \mathrm{~Hz}, 2 \mathrm{H}, \mathrm{OCH}_{2}\right), 2.00-2.10(\mathrm{~m}, 1 \mathrm{H}, \mathrm{CH}), 1.69-1.86(\mathrm{~m}, 2 \mathrm{H}$, $\left.\mathrm{CH}_{2}\right), 1.31\left(\mathrm{t}, J=6.97 \mathrm{~Hz}, 3 \mathrm{H}, \mathrm{CH}_{3}\right), 0.87-0.98\left(\mathrm{~m}, 6 \mathrm{H}, \mathrm{CH}_{3}\right)$. HRMS (ESI, $[\mathrm{M}+\mathrm{H}]^{+}$): calcd for $\mathrm{C}_{29} \mathrm{H}_{30} \mathrm{~N}_{5} \mathrm{O}_{2}, 480.2400$; found, 480.2404. $[\alpha]_{\mathrm{D}}^{20}+69.5 \pm 0.55(c=1$, DMSO $)$.

$N^{2}$-[3-Cyano-2-(2'-ethoxybiphenyl-4-yl)-1,7-naphthyridin-4-yl]O-methylserinamide (21). Step 1: $N^{2}$-[2-(4-Bromophenyl)-3-cyano1,7 -naphthyridin-4-yl]-O-methylserinamide ( $96 \mathrm{mg}$, quantitative) was prepared analogously to $\mathbf{1 3}$, from $\mathbf{8 b}$ and $O$-methylserinamide hydrochloride (1:1) (commercially available, CAS-RN: [17463-682]). MS $\left(\mathrm{ESI}^{+}\right): m / z=428.2[\mathrm{M}+\mathrm{H}]^{+}$. The crude compound was directly used in the next step. Step 2: Compound 21 (30 mg, 18\%) was prepared analogously to 17 , from $N^{2}$-[2-(4-bromophenyl)-3cyano-1,7-naphthyridin-4-yl]-O-methylserinamide $(150 \mathrm{mg}, 0.352$ $\mathrm{mmol}$ ) and (2-ethoxyphenyl)boronic acid ( $88 \mathrm{mg}, 0.528 \mathrm{mmol}$ ) commercially available, CAS-RN: [213211-69-9]. LC-MS (acidic conditions): ${ }^{t} \mathrm{R}=1.22 \mathrm{~min}$. MS $\left(\mathrm{ESI}^{+}\right): \mathrm{m} / z=468.6[\mathrm{M}+\mathrm{H}]^{+} .{ }^{1} \mathrm{H}$ NMR $\left(400 \mathrm{MHz}, \mathrm{DMSO}-d_{6}\right): \delta=9.26(\mathrm{~s}, 1 \mathrm{H}$, pyridine $), 8.67(\mathrm{~d}, J=$ $5.83 \mathrm{~Hz}, 1 \mathrm{H}$, pyridine), $8.31(\mathrm{~d}, J=5.58 \mathrm{~Hz}, 1 \mathrm{H}$, pyridine), $7.79-7.89$ (m, 4H, phenyl, NH), 7.67-7.72 (m, 2H, phenyl), $7.50(\mathrm{~s}, 1 \mathrm{H}, \mathrm{NH})$, 
7.34-7.43 (m, 2H, phenyl), 7.14 (d, $J=7.85 \mathrm{~Hz}, 1 \mathrm{H}$, phenyl), $7.07(\mathrm{t}$, $J=7.14 \mathrm{~Hz}, 1 \mathrm{H}$, phenyl), 5.26 (ddd, $J=4.44,6.46,8.36 \mathrm{~Hz}, 1 \mathrm{H}, \mathrm{CH}-$ $\mathrm{C}(\mathrm{O})), 4.09\left(\mathrm{q}, J=6.84 \mathrm{~Hz}, 2 \mathrm{H}, \mathrm{OCH}_{2}\right), 3.89-3.98\left(\mathrm{~m}, 2 \mathrm{H}, \mathrm{OCH}_{2}\right)$, $3.29-3.32\left(\mathrm{~m}, 3 \mathrm{H}, \mathrm{OCH}_{3}\right), 1.31\left(\mathrm{t}, J=6.97 \mathrm{~Hz}, 3 \mathrm{H}, \mathrm{CH}_{3}\right)$. HRMS (ESI, $[\mathrm{M}+\mathrm{H}]^{+}$): calcd for $\mathrm{C}_{27} \mathrm{H}_{26} \mathrm{~N}_{5} \mathrm{O}_{3}, 468.2036$; found, 468.2032. (2R)-2-\{[3-Cyano-2-(2'-ethoxybiphenyl-4-yl)-1,7-naphthyridin-4yl]amino\}-N-(2,2-difluoroethyl)butanamide (22). Compound 22 (26 $\mathrm{mg}, 23 \%$ ) was prepared analogously to 23 , from acid 2 (100 $\mathrm{mg}, 0.221 \mathrm{mmol}$ ) and 2,2-difluoroethanamine $(36 \mathrm{mg}, 0.442 \mathrm{mmol}$, CAS-RN: [430-67-1]). LC-MS (basic conditions): ${ }^{t} \mathrm{R}=1.31 \mathrm{~min}$. MS $\left(\mathrm{ESI}^{+}\right): m / z=516.4[\mathrm{M}+\mathrm{H}]^{+} .{ }^{1} \mathrm{H}$ NMR $\left(400 \mathrm{MHz}, \mathrm{DMSO}-d_{6}\right): \delta=$ $9.26(\mathrm{~s}, 1 \mathrm{H}$, pyridine $), 8.66-8.73(\mathrm{~m}, 2 \mathrm{H}$, pyridine, $\mathrm{NH}), 8.44(\mathrm{~d}, J=$ $5.58 \mathrm{~Hz}, 1 \mathrm{H}$, pyridine), 7.82-7.91 (m, 3H, phenyl, $\mathrm{NH}), 7.67-7.71$ (m, 2H, phenyl), 7.34-7.42 (m, 2H, phenyl), $7.14(\mathrm{~d}, J=7.60 \mathrm{~Hz}$, $1 \mathrm{H}$, phenyl), $7.06(\mathrm{dt}, J=0.89,7.41 \mathrm{~Hz}, 1 \mathrm{H}$, phenyl), $6.00(\mathrm{~m}, 1 \mathrm{H}$, $\mathrm{CHF}_{2}$ ), $5.00(\mathrm{dt}, J=4.94,8.55 \mathrm{~Hz}, 1 \mathrm{H}, \mathrm{CH}-\mathrm{C}(\mathrm{O})), 4.00-4.12(\mathrm{~m}$, $\left.2 \mathrm{H}, \mathrm{OCH}_{2}\right), 3.42-3.65\left(\mathrm{~m}, 2 \mathrm{H}, \mathrm{NCH}_{2}\right), 1.99-2.15\left(\mathrm{~m}, 2 \mathrm{H}, \mathrm{CH}_{2}\right)$, $1.31\left(\mathrm{t}, J=6.84 \mathrm{~Hz}, 3 \mathrm{H}, \mathrm{CH}_{3}\right), 0.98\left(\mathrm{t}, J=7.35 \mathrm{~Hz}, 3 \mathrm{H}, \mathrm{CH}_{3}\right)$. HRMS (ESI, $[\mathrm{M}+\mathrm{H}]^{+}$): calcd for $\mathrm{C}_{29} \mathrm{H}_{28} \mathrm{~F}_{2} \mathrm{~N}_{5} \mathrm{O}_{2}, 516.2211$; found, 516.2211. $[\alpha]_{\mathrm{D}}^{20}+91.4 \pm 0.5(c=1, \mathrm{DMSO})$.

(2R)-2-\{[3-Cyano-2-(2'-ethoxybiphenyl-4-yl)-1,7-naphthyridin-4yl]amino $\}-N, N$-dimethylbutanamide (23). To a solution of acid 2 $(100 \mathrm{mg}, 0.21 \mathrm{mmol})$ in THF $(5.4 \mathrm{~mL})$ were added DIPEA $(0.11 \mathrm{~mL}$, $0.63 \mathrm{mmol})$ and HATU $(160 \mathrm{mg}, 0.42 \mathrm{mmol})$. The reaction mixture was stirred at $\mathrm{rt}$ for $10 \mathrm{~min}$, and $2 \mathrm{M}$ dimethylamine in THF (1.05 $\mathrm{mL}, 2.1 \mathrm{mmol}$ ) was added. The reaction mixture was stirred at $\mathrm{rt}$ for $60 \mathrm{~h}$, then poured into $\mathrm{H}_{2} \mathrm{O}$, and the precipitate was isolated by filtration. The crude product was purified by HPLC (gradient: water $50 \%$ /acetonitrile $50 \%$-water $20 \%$ /acetonitrile $80 \%$ ) to yield $23(60$ $\mathrm{mg}, 59 \%)$. LC-MS (acidic conditions): ${ }^{t} \mathrm{R}=1.34 \mathrm{~min} . \mathrm{MS}\left(\mathrm{ESI}^{+}\right): \mathrm{m} /$ $z=480.8[\mathrm{M}+\mathrm{H}]^{+}$. ${ }^{1} \mathrm{H}$ NMR $\left(400 \mathrm{MHz}, \mathrm{DMSO}-d_{6}\right): \delta=9.25(\mathrm{~s}$, $1 \mathrm{H}$, pyridine), $8.67(\mathrm{~d}, J=5.58 \mathrm{~Hz}, 1 \mathrm{H}$, pyridine), 8.51 (d, $J=6.08$ $\mathrm{Hz}, 1 \mathrm{H}$, pyridine), 7.94 (br d, $J=8.36 \mathrm{~Hz}, 1 \mathrm{H}$, phenyl), 7.81-7.87 $(\mathrm{m}, J=8.36 \mathrm{~Hz}, 2 \mathrm{H}$, phenyl), 7.64-7.72 $(\mathrm{m}, J=8.36 \mathrm{~Hz}, 2 \mathrm{H}$, phenyl), 7.33-7.43 (m, 2H, phenyl, NH), $7.14(\mathrm{~d}, J=8.35 \mathrm{~Hz}, 1 \mathrm{H}$, phenyl), $7.06(\mathrm{t}, J=6.98 \mathrm{~Hz}, 1 \mathrm{H}$, phenyl), $5.36(\mathrm{dt}, J=3.93,8.30 \mathrm{~Hz}$, $1 \mathrm{H}, \mathrm{CH}-\mathrm{C}(\mathrm{O})), 4.09\left(\mathrm{q}, J=7.01 \mathrm{~Hz}, 2 \mathrm{H}, \mathrm{OCH}_{2}\right), 3.08(\mathrm{~s}, 3 \mathrm{H}$, $\left.\mathrm{NCH}_{3}\right), 2.87\left(\mathrm{~s}, 3 \mathrm{H}, \mathrm{NCH}_{3}\right), 1.90-2.09\left(\mathrm{~m}, 2 \mathrm{H}, \mathrm{CH}_{2}\right), 1.31(\mathrm{t}, J=$ $\left.6.84 \mathrm{~Hz}, 3 \mathrm{H}, \mathrm{CH}_{3}\right), 1.02\left(\mathrm{t}, J=7.35 \mathrm{~Hz}, 3 \mathrm{H}, \mathrm{CH}_{3}\right)$. HRMS (ESI, [M $\left.+\mathrm{H}]^{+}\right)$: calcd for $\mathrm{C}_{29} \mathrm{H}_{30} \mathrm{~N}_{5} \mathrm{O}_{2}, 480.2400$; found, 480.2401. $[\alpha]_{\mathrm{D}}^{20}$ $+46.6 \pm 0.67(c=1, \mathrm{DMSO})$

(2R)-2-\{[3-Cyano-2-(2'-ethoxybiphenyl-4-yl)-1,7-naphthyridin-4yl]amino\}- $N$-(methylsulfonyl)butanamide (24). A mixture of acid 2 (200 mg, $0.442 \mathrm{mmol})$, methanesulfonamide (50.45 mg, $0.53 \mathrm{mmol})$, DMAP (162 mg, $1.33 \mathrm{mmol}$ ), and 1-(3-Dimethylaminopropyl)-3ethylcarbodiimid hydrochloride $(169.5 \mathrm{mg}, 0.884 \mathrm{mmol})$ in DMF ( $2.5 \mathrm{~mL}$ ) was stirred at $\mathrm{rt}$ for $17 \mathrm{~h} . \mathrm{H}_{2} \mathrm{O}$ and $\mathrm{DCM}$ were added, and the mixture was extracted with $\mathrm{DCM}(3 \times)$. The combined organic layers were dried over $\mathrm{Na}_{2} \mathrm{SO}_{4}$, and the solvent was removed under reduced pressure. The residue was purified by preparative HPLC (basic conditions) to yield $24(40 \mathrm{mg}, 17 \%)$. LC-MS (acidic conditions): ${ }^{t} \mathrm{R}=1.24 \mathrm{~min}$. $\mathrm{MS}\left(\mathrm{ESI}^{+}\right): m / z=530.2[\mathrm{M}+\mathrm{H}]^{+} .{ }^{1} \mathrm{H}$ NMR ( $400 \mathrm{MHz}$, DMSO- $\left.d_{6}\right): \delta=9.24$ (s, $1 \mathrm{H}$, pyridine), 8.67 (d, $J=$ $5.83 \mathrm{~Hz}, 1 \mathrm{H}$, pyridine), $8.12(\mathrm{br} \mathrm{d}, J=7.60 \mathrm{~Hz}, 2 \mathrm{H}$, pyridine, $\mathrm{NH}$ ), 7.81-7.87 (m, $2 \mathrm{H}$, phenyl), 7.66-7.71 (m, $2 \mathrm{H}$, phenyl), $7.41(\mathrm{~d}, J=$ $7.18 \mathrm{~Hz}, 1 \mathrm{H}$, phenyl), $7.36(\mathrm{t}, J=7.76 \mathrm{~Hz}, 1 \mathrm{H}$, phenyl), 7.01-7.21 $(\mathrm{m}, 3 \mathrm{H}$, phenyl, NH), 4.78-4.85 (m, $1 \mathrm{H}, \mathrm{CH}-\mathrm{C}(\mathrm{O})), 4.10(\mathrm{q}, J=$ $\left.6.84 \mathrm{~Hz}, 2 \mathrm{H}, \mathrm{OCH}_{2}\right), 2.89\left(\mathrm{~s}, 3 \mathrm{H}, \mathrm{CH}_{3}\right), 1.95-2.12\left(\mathrm{~m}, 2 \mathrm{H}, \mathrm{CH}_{2}\right)$, $1.31\left(\mathrm{t}, J=6.97 \mathrm{~Hz}, 3 \mathrm{H}, \mathrm{CH}_{3}\right), 0.88\left(\mathrm{br} \mathrm{t}, J=7.10 \mathrm{~Hz}, 3 \mathrm{H}, \mathrm{CH}_{3}\right)$. HRMS (ESI, $[\mathrm{M}+\mathrm{H}]^{+}$): calcd for $\mathrm{C}_{28} \mathrm{H}_{28} \mathrm{~N}_{5} \mathrm{O}_{4} \mathrm{~S}, 530.1862$; found, 530.1868. $[\alpha]_{\mathrm{D}}^{20}+40.5 \pm 0.57(c=1, \mathrm{DMSO})$.

(2R)-2-\{[3-Cyano-2-(2'-ethoxybiphenyl-4-yl)-1,7-naphthyridin-4yl]amino\}-N-(cyclopropylsulfonyl)butanamide (25). Compound 25 (34 mg, 14\%) was prepared analogously to 24 , from acid $2(200 \mathrm{mg}$, $0.442 \mathrm{mmol}$ ) and cyclopropanesulfonamide $(64 \mathrm{mg}, 0.53 \mathrm{mmol}$, CAS$\mathrm{RN}$ : [154350-29-5]). LC-MS (acidic conditions): ${ }^{t} \mathrm{R}=1.31 \mathrm{~min} . \mathrm{MS}$ $\left(\mathrm{ESI}^{+}\right): m / z=556.5[\mathrm{M}+\mathrm{H}]^{+} .{ }^{1} \mathrm{H}$ NMR $\left(400 \mathrm{MHz}, \mathrm{DMSO}-d_{6}\right): \delta=$ $9.24(\mathrm{~s}, 1 \mathrm{H}$, pyridine $), 8.67(\mathrm{~d}, J=5.58 \mathrm{~Hz}, 1 \mathrm{H}$, pyridine $), 8.51(\mathrm{~d}, J=$ $7.86 \mathrm{~Hz}, 1 \mathrm{H}, \mathrm{NH}), 8.11$ (br d, $J=4.31 \mathrm{~Hz}, 2 \mathrm{H}$, pyridine, $\mathrm{NH}), 7.81-$ $7.86(\mathrm{~m}, 2 \mathrm{H}$, phenyl), 7.66-7.71 (m, 2H, phenyl), 7.34-7.42 (m, $2 \mathrm{H}$, phenyl), 7.04-7.20 (m, 2H, phenyl), 4.85 (br s, $1 \mathrm{H}, \mathrm{CH}-\mathrm{C}(\mathrm{O})$ ), 4.10 $\left(\mathrm{q}, J=6.84 \mathrm{~Hz}, 2 \mathrm{H}, \mathrm{OCH}_{2}\right), 2.82-2.90(\mathrm{~m}, 1 \mathrm{H}), 2.05(\mathrm{qd}, J=6.65$, $\left.12.99 \mathrm{~Hz}, 2 \mathrm{H}, \mathrm{CH}_{2}\right), 1.31\left(\mathrm{t}, J=6.97 \mathrm{~Hz}, 3 \mathrm{H}, \mathrm{CH}_{3}\right), 0.61-1.01(\mathrm{~m}$, $7 \mathrm{H}$, cyclopropyl, $\mathrm{CH}_{3}$ ). HRMS (ESI, $[\mathrm{M}+\mathrm{H}]^{+}$): calcd for $\mathrm{C}_{30} \mathrm{H}_{30} \mathrm{~N}_{5} \mathrm{O}_{4} \mathrm{~S}$, 556.2019; found, 556.2026.

2-(2'-Ethoxybiphenyl-4-yl)-4-\{[(3R)-2-oxopyrrolidin-3-yl]amino\}1,7-naphthyridine-3-carbonitrile (26). Compound 26 (66 mg, 53\%) was prepared analogously to 13 , from 4-bromo-2-(2'-ethoxybiphenyl4-yl)-1,7-naphthyridine-3-carbonitrile (synthesis as for compound 19, step 2) and (3R)-3-aminopyrrolidin-2-one (CAS-RN: [121010-864]). LC-MS (acidic conditions): ${ }^{t} \mathrm{R}=1.16 \mathrm{~min}$. MS $\left(\mathrm{ESI}^{+}\right): \mathrm{m} / z=$ $450.1[\mathrm{M}+\mathrm{H}]^{+} .{ }^{1} \mathrm{H}$ NMR $\left(400 \mathrm{MHz}\right.$, DMSO- $\left.d_{6}\right): \delta=9.25(\mathrm{~s}, 1 \mathrm{H}$, pyridine), 8.66 (d, $J=5.83 \mathrm{~Hz}, 1 \mathrm{H}$, pyridine), $8.34(\mathrm{~d}, J=5.68 \mathrm{~Hz}$, $1 \mathrm{H}$, pyridine), $8.30(\mathrm{~d}, J=9.09 \mathrm{~Hz}, 1 \mathrm{H}, \mathrm{NH}), 8.14(\mathrm{~s}, 1 \mathrm{H}, \mathrm{NH})$, 7.85-7.89 (m, $2 \mathrm{H}$, phenyl), 7.66-7.71 (m, 2H, phenyl), $7.41(\mathrm{~d}, J=$ $7.28 \mathrm{~Hz}, 1 \mathrm{H}$, phenyl), 7.37 (t, $J=7.74 \mathrm{~Hz}, 1 \mathrm{H}$, phenyl), $7.14(\mathrm{~d}, J=$ $7.87 \mathrm{~Hz}, 1 \mathrm{H}$, phenyl), $7.06(\mathrm{t}, J=7.45 \mathrm{~Hz}, 1 \mathrm{H}$, phenyl), 5.23-5.30 $(\mathrm{m}, 1 \mathrm{H}, \mathrm{NCH}), 4.09\left(\mathrm{q}, J=6.84 \mathrm{~Hz}, 2 \mathrm{H}, \mathrm{OCH}_{2}\right), 3.26-3.32(\mathrm{~m}, 2 \mathrm{H}$, $\left.\mathrm{NCH}_{2}\right), 2.64-2.73\left(\mathrm{~m}, 1 \mathrm{H}, \mathrm{CH}_{2}\right), 2.24-2.35\left(\mathrm{~m}, 1 \mathrm{H}, \mathrm{CH}_{2}\right), 1.31(\mathrm{t}$, $\left.J=6.97 \mathrm{~Hz}, 3 \mathrm{H}, \mathrm{CH}_{3}\right)$. HRMS (ESI, $\left.[\mathrm{M}+\mathrm{H}]^{+}\right)$: calcd for $\mathrm{C}_{27} \mathrm{H}_{24} \mathrm{~N}_{5} \mathrm{O}_{2}, 450.1931$; found, 450.1931 .

$N$-[2-\{[3-Cyano-2-(2'-ethoxybiphenyl-4-yl)-1,7-naphthyridin-4yl]amino\}butyl]cyclopropanesulfonamide (27). Compound 27 (45 $\mathrm{mg}, 36 \%)$ was prepared analogously to 13 , from 4-bromo-2-(2'ethoxybiphenyl-4-yl)-1,7-naphthyridine-3-carbonitrile (100 mg, 0.232 mmol, synthesis as for compound 19, step 2) and $\mathrm{N}$-(2-aminobutyl)cyclopropanesulfonamide $(54 \mathrm{mg}, 0.279 \mathrm{mmol}$, commercially available). LC-MS (acidic conditions): ${ }^{t} \mathrm{R}=1.34 \mathrm{~min} . \mathrm{MS}\left(\mathrm{ESI}^{+}\right)$: $m / z=542.8[\mathrm{M}+\mathrm{H}]^{+} .{ }^{1} \mathrm{H}$ NMR $\left(400 \mathrm{MHz}, \mathrm{DMSO}-d_{6}\right): \delta=9.22(\mathrm{~s}$, $1 \mathrm{H}$, pyridine $), 8.65(\mathrm{~d}, J=5.83 \mathrm{~Hz}, 1 \mathrm{H}$, pyridine $), 8.41(\mathrm{~d}, J=5.83$ $\mathrm{Hz}, 1 \mathrm{H}$, pyridine), $7.78-7.90(\mathrm{~m}, 2 \mathrm{H}$, phenyl), 7.62-7.74 (m, $3 \mathrm{H}$, phenyl, NH), 7.33-7.45 (m, 3H, phenyl, NH), 7.03-7.17 (m, 2H, phenyl), 4.74-4.83 (m, 1H, NCH), 4.00-4.12 (m, $\left.2 \mathrm{H}, \mathrm{OCH}_{2}\right)$, 3.34-3.44 (m, $\left.2 \mathrm{H}, \mathrm{NCH}_{2}\right), 2.52-2.60(\mathrm{~m}, 1 \mathrm{H}$, cyclopropyl), 1.80 $\left(\mathrm{qt}, J=7.02,14.18 \mathrm{~Hz}, 2 \mathrm{H}, \mathrm{CH}_{2}\right), 1.31\left(\mathrm{t}, J=6.97 \mathrm{~Hz}, 3 \mathrm{H}, \mathrm{CH}_{3}\right)$, 0.84-1.04 (m, 7H, $\mathrm{CH}_{3}$, cyclopropyl). HRMS (ESI, $\left.[\mathrm{M}+\mathrm{H}]^{+}\right)$: calcd for $\mathrm{C}_{30} \mathrm{H}_{32} \mathrm{~N}_{5} \mathrm{O}_{3} \mathrm{~S}$, 542.2227; found, 542.2228.

(2S)-3-[3-Cyano-2-(2'-ethoxybiphenyl-4-yl)-1,7-naphthyridin-4yl]-2-methylpropanoic Acid (28). A mixture of 4-bromo-2-(2'ethoxybiphenyl-4-yl)-1,7-naphthyridine-3-carbonitrile (190 mg, $0.442 \mathrm{mmol}$, synthesis as for compound 19 , step 2$)$, bromo[(2S)-3methoxy-2-methyl-3-oxopropyl]zinc $(272 \mathrm{mg}, 1.104 \mathrm{mmol}$, commercially available, CAS-RN: [312693-18-8]), tri-tert-butylphosphonium tetrafluoroborate $(12.8 \mathrm{mg}, 0.044 \mathrm{mmol})$, and $\mathrm{Pd}_{2}(\mathrm{dba})_{3}(4.04 \mathrm{mg}$, $0.004 \mathrm{mmol}$ ) was stirred at $\mathrm{rt}$ for $18 \mathrm{~h}$. Then, the mixture was concentrated to dryness and the residue was purified by flash column chromatography (gradient: $n$-hexane/EtOAc). A mixture of the resulting methyl (2S)-3-[3-cyano-2-(2'-ethoxybiphenyl-4-yl)-1,7naphthyridin-4-yl]-2-methylpropanoate and $2 \mathrm{M}$ aq $\mathrm{NaOH}$ solution $(0.55 \mathrm{~mL})$ in $\mathrm{MeOH}(10 \mathrm{~mL})$ was stirred at $\mathrm{rt}$ for $18 \mathrm{~h}$. The $\mathrm{pH}$ was adjusted to 7 by addition of aq $\mathrm{HCl}$. DCM and $\mathrm{H}_{2} \mathrm{O}$ were added, and the aqueous layer was extracted with DCM $(3 \times)$. The combined organic layers were concentrated to dryness and the resulting residue was purified by HPLC (acidic conditions) to yield 28 (12 mg, 6\% over 2 steps). LC-MS (acidic conditions): ${ }^{t} \mathrm{R}=1.38 \mathrm{~min}$. $\mathrm{MS}\left(\mathrm{ESI}^{+}\right)$: $m / z=438.5[\mathrm{M}+\mathrm{H}]^{+} .{ }^{1} \mathrm{H} \mathrm{NMR}\left(400 \mathrm{MHz}, \mathrm{CD}_{3} \mathrm{OD}\right): \delta=9.47(\mathrm{~s}$, $1 \mathrm{H}$, pyridine), 8.69 (d, $J=6.08 \mathrm{~Hz}, 1 \mathrm{H}$, pyridine), 8.30 (dd, $J=0.76$, $6.08 \mathrm{~Hz}, 1 \mathrm{H}$, pyridine), 7.99-8.04 (m, $2 \mathrm{H}$, phenyl), 7.73-7.77 (m, $2 \mathrm{H}$, phenyl), $7.41(\mathrm{~d}, J=7.20 \mathrm{~Hz}, 1 \mathrm{H}$, phenyl), $7.34(\mathrm{t}, J=7.85 \mathrm{~Hz}$, $1 \mathrm{H}$, phenyl), 7.09 (d, $J=8.02 \mathrm{~Hz}, 1 \mathrm{H}$, phenyl), $7.05(\mathrm{t}, J=7.43 \mathrm{~Hz}$, $1 \mathrm{H}$, phenyl), 4.09 (q, $J=7.01 \mathrm{~Hz}, 2 \mathrm{H}, \mathrm{OCH}_{2}$ ), 3.87 (dd, $J=7.48$, $\left.13.31 \mathrm{~Hz}, 1 \mathrm{H}, \mathrm{Ar}-\mathrm{CH}_{2}\right), 3.43-3.49\left(\mathrm{~m}, 1 \mathrm{H}, \mathrm{Ar}-\mathrm{CH}_{2}\right), 2.89(\mathrm{q}, J=$ $7.18 \mathrm{~Hz}, 1 \mathrm{H}, \mathrm{CH}-\mathrm{C}(\mathrm{O})), 1.24-1.39\left(\mathrm{~m}, 6 \mathrm{H}, \mathrm{CH}_{3}\right), 0.81-1.09(\mathrm{~m}$, $1 \mathrm{H})$.

(2S)-3-[3-Cyano-2-(2'-ethoxybiphenyl-4-yl)-1,7-naphthyridin-4yl]-2-methylpropanamide (29). Compound $29(10 \mathrm{mg}, 54 \%)$ was prepared analogously to 23 , from acid $28(15 \mathrm{mg}, 0.035 \mathrm{mmol})$ and ammonium chloride $(9 \mathrm{mg}, 0.176 \mathrm{mmol}$ ). DMF was used instead of THF as the solvent. LC-MS (acidic conditions): ${ }^{t} \mathrm{R}=1.24 \mathrm{~min}$. MS $\left(\mathrm{ESI}^{+}\right): m / z=437.5[\mathrm{M}+\mathrm{H}]^{+} .{ }^{1} \mathrm{H} \mathrm{NMR}\left(400 \mathrm{MHz}, \mathrm{DMSO}-d_{6}\right): \delta=$ 
$9.53(\mathrm{~d}, J=0.76 \mathrm{~Hz}, 1 \mathrm{H}$, pyridine $), 8.78(\mathrm{~d}, J=5.57 \mathrm{~Hz}, 1 \mathrm{H}$, pyridine), $8.21(\mathrm{~d}, J=5.88 \mathrm{~Hz}, 1 \mathrm{H}$, pyridine), $8.00(\mathrm{~d}, J=8.6 \mathrm{~Hz}, 2 \mathrm{H}$, phenyl), 7.77 (d, $J=7.82 \mathrm{~Hz}, 2 \mathrm{H}$, phenyl), 7.35-7.51 (m, $2 \mathrm{H}$, phenyl), $7.30(\mathrm{~s}, 1 \mathrm{H}, \mathrm{NH}), 7.16(\mathrm{~d}, J=8.46 \mathrm{~Hz}, 1 \mathrm{H}$, phenyl), $7.08(\mathrm{t}$, $J=7.05 \mathrm{~Hz}, 1 \mathrm{H}$, phenyl), $6.82(\mathrm{~s}, 1 \mathrm{H}, \mathrm{NH}), 4.10(\mathrm{q}, J=7.10 \mathrm{~Hz}, 2 \mathrm{H}$, $\mathrm{OCH}_{2}$ ), 3.70 (dd, $\left.J=7.98,13.31 \mathrm{~Hz}, 1 \mathrm{H}, \mathrm{Ar}-\mathrm{CH}_{2}\right), 3.33(\mathrm{~m}, 1 \mathrm{H}, \mathrm{Ar}-$ $\left.\mathrm{CH}_{2}\right), 2.81-2.86(\mathrm{~m}, 1 \mathrm{H}, \mathrm{CH}-\mathrm{C}(\mathrm{O})), 1.31\left(\mathrm{t}, J=6.97 \mathrm{~Hz}, 3 \mathrm{H}, \mathrm{CH}_{3}\right)$, $1.17\left(\mathrm{~d}, J=6.8 \mathrm{~Hz}, 3 \mathrm{H}, \mathrm{CH}_{3}\right)$.

4-Amino-2-(2'-ethoxybiphenyl-4-yl)-1,7-naphthyridine-3-carbonitrile (30). A mixture of 4-bromo-2-(2'-ethoxybiphenyl-4-yl)-1,7naphthyridine-3-carbonitrile $(1.3 \mathrm{~g}, 3.02 \mathrm{mmol}$, synthesis as for compound 19, step 2), ammonium hydroxide $(212 \mathrm{mg}, 6.04 \mathrm{mmol})$, and $\mathrm{Et}_{3} \mathrm{~N}(2 \mathrm{~mL}, 14.3 \mathrm{mmol})$ in 1,4-dioxane $(40 \mathrm{~mL})$ was stirred at $\mathrm{rt}$ for $17 \mathrm{~h}$. Then, the mixture was concentrated under reduced pressure and the residue was purified by flash column chromatography (eluent: $n$-hexane/EtOAc gradient) to yield $30(700 \mathrm{mg}, 63 \%)$. LC-MS (acidic conditions): ${ }^{t} \mathrm{R}=1.19 \mathrm{~min}$. MS $\left(\mathrm{ESI}^{+}\right): m / z=367.3[\mathrm{M}+\mathrm{H}]^{+} .{ }^{1} \mathrm{H}$ NMR (400 MHz, DMSO- $\left.d_{6}\right): \delta=9.22(\mathrm{~s}, 1 \mathrm{H}$, pyridine), 8.60 (d, $J=$ $5.58 \mathrm{~Hz}, 1 \mathrm{H}$, pyridine), 8.31 (br dd, $J=0.76,5.83 \mathrm{~Hz}, 3 \mathrm{H}$, pyridine, $\left.\mathrm{NH}_{2}\right), 7.86-7.91(\mathrm{~m}, 2 \mathrm{H}$, phenyl), 7.62-7.75 (m, $2 \mathrm{H}$, phenyl), 7.34$7.42(\mathrm{~m}, 2 \mathrm{H}$, phenyl), $7.14(\mathrm{~d}, J=8.36 \mathrm{~Hz}, 1 \mathrm{H}$, phenyl), $7.06(\mathrm{t}, J=$ $7.50 \mathrm{~Hz}, 1 \mathrm{H}$, phenyl), 4.05-4.13 (m, $\left.2 \mathrm{H}, \mathrm{OCH}_{2}\right), 1.31(\mathrm{t}, J=6.84$ $\mathrm{Hz}, 3 \mathrm{H}, \mathrm{CH}_{3}$ ). HRMS (ESI, $[\mathrm{M}+\mathrm{H}]^{+}$): calcd for $\mathrm{C}_{23} \mathrm{H}_{19} \mathrm{~N}_{4} \mathrm{O}$, 367.1560; found, 367.1557 .

2-(2'-Ethoxybiphenyl-4-yl)-1,7-naphthyridine-3-carbonitrile (31). Compound 31 was isolated as a byproduct of the following carbonylation reaction: To a suspension of 4-bromo-2-(2'-ethoxybiphenyl-4-yl)-1,7-naphthyridine-3-carbonitrile (1 g, $2.32 \mathrm{mmol}$, synthesis as for compound 19, step 2) in DMF $(20 \mathrm{~mL})$ were added triethylsilane $(0.75 \mathrm{~mL}, 4.65 \mathrm{mmol}), \mathrm{Et}_{3} \mathrm{~N}(0.81 \mathrm{~mL}, 5.8$ $\mathrm{mmol}$ ), and [1,3-bis(diphenylphosphino)propane]palladium(II) dichloride $(70 \mathrm{mg}, 0.116 \mathrm{mmol})$. The reaction mixture was flushed with $\mathrm{CO}(3 \times)$ and stirred under CO pressure (12.9 bar) at rt for $30 \mathrm{~min}$. The pressure was released, and the reaction vessel was evacuated and then stirred under $\mathrm{CO}$ pressure $(15.8 \mathrm{bar})$ at $80{ }^{\circ} \mathrm{C}$ overnight. The reaction mixture was concentrated to dryness, and the residue was purified by flash chromatography flash column chromatography (eluent: $n$-hexane/EtOAc gradient) to yield 31 (280 mg, 33\%). MS $\left(\mathrm{ESI}^{+}\right): m / z=352.1[\mathrm{M}+\mathrm{H}]^{+} .{ }^{1} \mathrm{H}$ NMR $\left(400 \mathrm{MHz}, \mathrm{DMSO}-d_{6}\right): \delta=$ $9.57(\mathrm{~s}, 1 \mathrm{H}$, pyridine $), 9.35(\mathrm{~d}, J=0.76 \mathrm{~Hz}, 1 \mathrm{H}$, pyridine $), 8.79(\mathrm{~d}, J=$ $5.58 \mathrm{~Hz}, 1 \mathrm{H}$, pyridine), 8.01-8.08 ( $\mathrm{m}, 3 \mathrm{H}$, phenyl, pyridine), $7.70-$ $7.80(\mathrm{~m}, 2 \mathrm{H}$, phenyl), 7.35-7.44 (m, $2 \mathrm{H}$, phenyl), 7.05-7.18 $(\mathrm{m}, 2 \mathrm{H}$, phenyl), 4.02-4.13 (m, $\left.2 \mathrm{H}, \mathrm{OCH}_{2}\right), 1.31\left(\mathrm{t}, J=6.97 \mathrm{~Hz}, 3 \mathrm{H}, \mathrm{CH}_{3}\right)$. HRMS (ESI, $[\mathrm{M}+\mathrm{H}]^{+}$): calcd for $\mathrm{C}_{23} \mathrm{H}_{18} \mathrm{~N}_{3} \mathrm{O}, 352.1451$; found, 352.1451 .

(2R)-2-\{[3-Cyano-2-(2'-fluorobiphenyl-4-yl)-1,7-naphthyridin-4yl]amino\}butanamide (32). A suspension of 12 (110 mg, 0.27 $\mathrm{mmol}$ ), (2-fluorophenyl)boronic acid $(56 \mathrm{mg}, 0.4 \mathrm{mmol}$, commercially available, CAS-RN: [1993-03-9]), XPhos Pd G2 (42 mg, 0.05 $\mathrm{mmol})$, and $0.5 \mathrm{M}$ aq potassium phosphate $(1.61 \mathrm{~mL}, 0.80 \mathrm{mmol})$ in THF $(3.2 \mathrm{~mL})$ was stirred at $\mathrm{rt}$ for $16 \mathrm{~h}$. The reaction mixture was poured into $\mathrm{H}_{2} \mathrm{O}$ and the precipitate was collected by filtration. The crude product was purified by HPLC (acidic conditions) to yield 32 (56 mg, 49\%) as a yellow solid. LC-MS (acidic conditions): ${ }^{t} \mathrm{R}=1.15$ min. MS $\left(\mathrm{ESI}^{+}\right): m / z=426.7[\mathrm{M}+\mathrm{H}]^{+} .{ }^{1} \mathrm{H}$ NMR $(400 \mathrm{MHz}$, DMSO- $\left.d_{6}\right): \delta=9.25(\mathrm{~s}, 1 \mathrm{H}$, pyridine $), 8.67(\mathrm{~d}, J=5.83 \mathrm{~Hz}, 1 \mathrm{H}$, pyridine), $8.38(\mathrm{~d}, J=5.83 \mathrm{~Hz}, 1 \mathrm{H}$, pyridine $), 7.78-7.93(\mathrm{~m}, 4 \mathrm{H}$, phenyl, NH), 7.73 (dd, $J=1.39,8.24 \mathrm{~Hz}, 2 \mathrm{H}$, phenyl), 7.61-7.69 (m, $1 \mathrm{H}$, phenyl), 7.33-7.51 (m, 4H, phenyl, NH), $5.00(\mathrm{dt}, J=4.69,8.05$ $\mathrm{Hz}, 1 \mathrm{H}, \mathrm{CH}-\mathrm{C}(\mathrm{O})), 1.96-2.18\left(\mathrm{~m}, 2 \mathrm{H}, \mathrm{CH}_{2}\right), 0.96(\mathrm{t}, J=7.22 \mathrm{~Hz}$, $3 \mathrm{H}, \mathrm{CH}_{3}$ ). HRMS (ESI, $\left.[\mathrm{M}+\mathrm{H}]^{+}\right)$: calcd for $\mathrm{C}_{25} \mathrm{H}_{21} \mathrm{FN}_{5} \mathrm{O}$, 426.1730; found, 426.1727. $[\alpha]_{\mathrm{D}}^{20}+42.6 \pm 0.32(c=1$, DMSO).

(2R)-2-\{[2-(2'-Chlorobiphenyl-4-yl)-3-cyano-1,7-naphthyridin-4yl]amino\}butanamide (33). Compound 33 (18 $\mathrm{mg}, 12 \%)$ was prepared analogously to 32, from 12 and (2-chlorophenyl)boronic acid (commercially available, CAS-RN: [3900-89-8]). LC-MS (acidic conditions): ${ }^{t} \mathrm{R}=1.19 \min . \mathrm{MS}\left(\mathrm{ESI}^{+}\right): m / z=442.3[\mathrm{M}+\mathrm{H}]^{+} .{ }^{1} \mathrm{H}$ NMR (400 MHz, DMSO- $\left.d_{6}\right): \delta=9.27$ (br s, $1 \mathrm{H}$, pyridine), $8.68(\mathrm{br}$ $\mathrm{s}, 1 \mathrm{H}$, pyridine), 8.38 (br d, $J=5.32 \mathrm{~Hz}, 1 \mathrm{H}$, pyridine), $7.78-7.92(\mathrm{~m}$, $4 \mathrm{H}$, phenyl, $\mathrm{NH}$ ), $7.40-7.64$ (m, 7H, phenyl, $\mathrm{NH}$ ), 5.00 (br d, $J=$
$5.07 \mathrm{~Hz}, 1 \mathrm{H}, \mathrm{CH}-\mathrm{C}(\mathrm{O})), 1.96-2.17\left(\mathrm{~m}, 2 \mathrm{H}, \mathrm{CH}_{2}\right), 0.96(\mathrm{t}, J=7.35$ $\mathrm{Hz}, 3 \mathrm{H}, \mathrm{CH}_{3}$ ). HRMS (ESI, $[\mathrm{M}+\mathrm{H}]^{+}$): calcd for $\mathrm{C}_{25} \mathrm{H}_{21} \mathrm{ClN}_{5} \mathrm{O}$, 442.1436; found, 442.1430.

(2R)-2-\{[3-Cyano-2-(2'-methylbiphenyl-4-yl)-1,7-naphthyridin-4yl]amino\}butanamide (34). Compound $34(47 \mathrm{mg}, 30 \%)$ was prepared analogously to 17, from 12 and (2-methylphenyl)boronic acid (commercially available, CAS-RN: [16419-60-6]). LC-MS (acidic conditions): ${ }^{t} \mathrm{R}=1.23 \mathrm{~min}$. $\mathrm{MS}\left(\mathrm{ESI}^{+}\right): \mathrm{m} / z=422.8[\mathrm{M}+$ $\mathrm{H}]^{+} .{ }^{1} \mathrm{H}$ NMR (400 MHz, DMSO- $\left.d_{6}\right): \delta=9.26$ (s, $1 \mathrm{H}$, pyridine), $8.67(\mathrm{~d}, J=5.83 \mathrm{~Hz}, 1 \mathrm{H}$, pyridine $), 8.37(\mathrm{~d}, J=5.83 \mathrm{~Hz}, 1 \mathrm{H}$, pyridine), 7.87 (d, $J=8.11 \mathrm{~Hz}, 2 \mathrm{H}$, phenyl), $7.83(\mathrm{br} \mathrm{d}, J=8.36 \mathrm{~Hz}$, $1 \mathrm{H}$, phenyl), $7.80(\mathrm{~s}, 1 \mathrm{H}, \mathrm{NH}), 7.52(\mathrm{~d}, J=8.11 \mathrm{~Hz}, 2 \mathrm{H}$, phenyl), $7.41(\mathrm{~s}, 1 \mathrm{H}, \mathrm{NH}), 7.25-7.38(\mathrm{~m}, 4 \mathrm{H}$, phenyl, $\mathrm{NH}), 5.00(\mathrm{dt}, J=4.94$, $8.05 \mathrm{~Hz}, 1 \mathrm{H}, \mathrm{CH}-\mathrm{C}(\mathrm{O})), 2.28-2.33\left(\mathrm{~s}, 3 \mathrm{H}, \mathrm{CH}_{3}\right), 1.95-2.18(\mathrm{~m}$, $\left.2 \mathrm{H}, \mathrm{CH}_{2}\right), 0.96\left(\mathrm{t}, J=7.22 \mathrm{~Hz}, 3 \mathrm{H}, \mathrm{CH}_{3}\right) .[\alpha]_{\mathrm{D}}^{20}+31.1 \pm 0.26(c=1$, DMSO).

(2R)-2-\{[3-Cyano-2-(2'-methoxybiphenyl-4-yl)-1,7-naphthyridin4-yl]amino\}butanamide (35). Compound $35(21 \mathrm{mg}, 16 \%)$ was prepared analogously to 17 , from 12 and (2-methoxyphenyl)boronic acid (commercially available, CAS-RN: [5720-06-9]). LC-MS (acidic conditions): ${ }^{t} \mathrm{R}=1.14 \mathrm{~min}$. MS $\left(\mathrm{ESI}^{+}\right): \mathrm{m} / z=438.7[\mathrm{M}+\mathrm{H}]^{+} .{ }^{1} \mathrm{H}$ NMR (400 MHz, DMSO- $\left.d_{6}\right): \delta=9.24(\mathrm{~s}, 1 \mathrm{H}$, pyridine), $8.67(\mathrm{~d}, J=$ $5.83 \mathrm{~Hz}, 1 \mathrm{H}$, pyridine ), $8.37(\mathrm{~d}, J=5.83 \mathrm{~Hz}, 1 \mathrm{H}$, pyridine $), 7.76-7.88$ (m, 4H, phenyl, NH), 7.64 (d, $J=8.36 \mathrm{~Hz}, 2 \mathrm{H}$, phenyl), 7.34-7.46 $(\mathrm{m}, 3 \mathrm{H}$, phenyl, $\mathrm{NH}), 7.16(\mathrm{~d}, J=8.36 \mathrm{~Hz}, 1 \mathrm{H}$, phenyl), $7.08(\mathrm{t}, J=$ $7.35 \mathrm{~Hz}, 1 \mathrm{H}$, phenyl), 4.96-5.04 (m, $1 \mathrm{H}, \mathrm{CH}-\mathrm{C}(\mathrm{O})), 3.81(\mathrm{~s}, 3 \mathrm{H}$, $\left.\mathrm{OCH}_{3}\right), 1.96-2.17\left(\mathrm{~m}, 2 \mathrm{H}, \mathrm{CH}_{2}\right), 0.83-1.02\left(\mathrm{~m}, 3 \mathrm{H}, \mathrm{CH}_{3}\right)$. HRMS (ESI, $\left.[\mathrm{M}+\mathrm{H}]^{+}\right)$: calcd for $\mathrm{C}_{26} \mathrm{H}_{24} \mathrm{~N}_{5} \mathrm{O}_{2}, 438.1931$; found, 438.1924.

(2R)-2-(\{3-Cyano-2-[2'-(propan-2-yl)biphenyl-4-yl]-1,7-naphthyridin-4-yl\}amino)butanamide (36). Compound 36 (7 mg, 5\%) was prepared analogously to 32 , from 12 and [2-(propan-2yl)phenyl]boronic acid (commercially available, CAS-RN: [8978712-2]). LC-MS (acidic conditions): ${ }^{t} \mathrm{R}=1.32 \mathrm{~min} . \mathrm{MS}\left(\mathrm{ESI}^{+}\right): \mathrm{m} / z=$ $450.4[\mathrm{M}+\mathrm{H}]^{+} .{ }^{1} \mathrm{H}$ NMR $\left(400 \mathrm{MHz}\right.$, DMSO- $\left.d_{6}\right): \delta=9.26(\mathrm{~s}, 1 \mathrm{H}$, pyridine), 8.67 (d, $J=5.83 \mathrm{~Hz}, 1 \mathrm{H}$, pyridine), $8.37(\mathrm{~d}, J=5.83 \mathrm{~Hz}$, $1 \mathrm{H}$, pyridine), 7.76-7.91 (m, 4H, phenyl, $\mathrm{NH}), 7.36-7.56(\mathrm{~m}, 5 \mathrm{H}$, phenyl, NH), 7.15-7.33 (m, $2 \mathrm{H}$, phenyl), 4.96-5.04 (m, $1 \mathrm{H}, \mathrm{CH}-$ $\mathrm{C}(\mathrm{O})), 3.04(\mathrm{td}, J=6.91,13.56 \mathrm{~Hz}, 1 \mathrm{H}, \mathrm{CH}), 1.95-2.19(\mathrm{~m}, 2 \mathrm{H}$, $\left.\mathrm{CH}_{2}\right), 1.16(\mathrm{~d}, J=6.84 \mathrm{~Hz}, 6 \mathrm{H}, i-\mathrm{Pr}), 0.96\left(\mathrm{t}, J=7.35 \mathrm{~Hz}, 3 \mathrm{H}, \mathrm{CH}_{3}\right)$.

(2R)-2-(\{3-Cyano-2-[2'-(dimethylamino)biphenyl-4-yl]-1,7-naphthyridin-4-yl\}amino)butanamide (37). Compound 37 (10 mg, 7\%) was prepared analogously to 32, from 12 and [2-(dimethylamino)phenyl]boronic acid (commercially available, CAS-RN: [89291-236]). LC-MS (acidic conditions): ${ }^{t} \mathrm{R}=0.99 \mathrm{~min}$. MS $\left(\mathrm{ESI}^{+}\right): \mathrm{m} / z=$ $451.3[\mathrm{M}+\mathrm{H}]^{+} .{ }^{1} \mathrm{H}$ NMR $\left(400 \mathrm{MHz}, \mathrm{DMSO}-d_{6}\right): \delta=9.27(\mathrm{~s}, 1 \mathrm{H}$, pyridine $), 8.67(\mathrm{~d}, J=5.82 \mathrm{~Hz}, 1 \mathrm{H}$, pyridine $), 8.39(\mathrm{~d}, J=5.83 \mathrm{~Hz}$, $1 \mathrm{H}$, pyridine), $7.76-7.90(\mathrm{~m}, 4 \mathrm{H}$, phenyl, $\mathrm{NH}), 7.70(\mathrm{~d}, J=7.71 \mathrm{~Hz}$, $2 \mathrm{H}$, phenyl), $7.41(\mathrm{~s}, 1 \mathrm{H}, \mathrm{NH}), 7.24-7.37(\mathrm{~m}, 2 \mathrm{H}$, phenyl), 7.15 (br s, $1 \mathrm{H}$, phenyl), 7.07 (br s, $1 \mathrm{H}$, phenyl), $5.00(\mathrm{dt}, J=4.69,8.05 \mathrm{~Hz}$, $1 \mathrm{H}, \mathrm{CH}-\mathrm{C}(\mathrm{O})), 2.52-2.58\left(\mathrm{~m}, 6 \mathrm{H}, \mathrm{NCH}_{3}\right), 1.96-2.18(\mathrm{~m}, 2 \mathrm{H}$, $\left.\mathrm{CH}_{2}\right), 0.96\left(\mathrm{t}, J=7.35 \mathrm{~Hz}, 3 \mathrm{H}, \mathrm{CH}_{3}\right)$.

(2R)-2-(\{3-Cyano-2-[2'-(methylamino)biphenyl-4-yl]-1,7-naphthyridin-4-yl\}amino)butanamide (38). Compound 38 (15 mg, 14\%) was prepared analogously to 32, from 12 and $\mathrm{N}$-methyl-2-(4,4,5,5tetramethyl-1,3,2-dioxaborolan-2-yl)aniline hydrochloride (1:1) (commercially available). LC-MS (acidic conditions): ${ }^{t} \mathrm{R}=1.09$ min. MS $\left(\mathrm{ESI}^{+}\right): m / z=437.5[\mathrm{M}+\mathrm{H}]^{+}$. ${ }^{1} \mathrm{H}$ NMR $(400 \mathrm{MHz}$, DMSO- $\left.d_{6}\right): \delta=9.25(\mathrm{~s}, 1 \mathrm{H}$, pyridine $), 8.66(\mathrm{~d}, J=5.83 \mathrm{~Hz}, 1 \mathrm{H}$, pyridine $), 8.37(\mathrm{~d}, J=5.83 \mathrm{~Hz}, 1 \mathrm{H}$, pyridine $), 7.74-7.88(\mathrm{~m}, 6 \mathrm{H}$, phenyl, NH), $7.41(\mathrm{~s}, 1 \mathrm{H}, \mathrm{NH}), 7.21(\mathrm{t}, J=7.86 \mathrm{~Hz}, 1 \mathrm{H}$, phenyl), $6.91(\mathrm{~d}, J=7.27 \mathrm{~Hz}, 1 \mathrm{H}$, phenyl), $6.87(\mathrm{~s}, 1 \mathrm{H}, \mathrm{NH}), 6.59(\mathrm{dd}, J=$ $1.52,8.11 \mathrm{~Hz}, 1 \mathrm{H}$, phenyl), 5.75-5.83 (m, $1 \mathrm{H}, \mathrm{NH}), 4.99(\mathrm{dt}, J=$ $4.82,8.11 \mathrm{~Hz}, 1 \mathrm{H}, \mathrm{CH}-\mathrm{C}(\mathrm{O})), 2.75\left(\mathrm{~d}, J=5.07 \mathrm{~Hz}, 3 \mathrm{H}, \mathrm{NCH}_{3}\right)$, $1.96-2.15\left(\mathrm{~m}, 2 \mathrm{H}, \mathrm{CH}_{2}\right), 0.96\left(\mathrm{t}, J=7.35 \mathrm{~Hz}, 3 \mathrm{H}, \mathrm{CH}_{3}\right)$.

(2R)-2-(\{3-Cyano-2-[2'-(difluoromethyl)biphenyl-4-yl]-1,7-naphthyridin-4-yl\}amino)butanamide (39). Compound 39 (35 mg, 31\%) was prepared analogously to 32, from 12 and 2-[2-(difluoromethyl)phenyl]-4,4,5,5-tetramethyl-1,3,2-dioxaborolane (CAS-RN: [87927572-6]). LC-MS (acidic conditions): ${ }^{t} \mathrm{R}=1.17 \mathrm{~min}$. $\mathrm{MS}\left(\mathrm{ESI}^{+}\right): \mathrm{m} / z=$ $458.4[\mathrm{M}+\mathrm{H}]^{+} .{ }^{1} \mathrm{H}$ NMR (400 MHz, DMSO- $\left.d_{6}\right): \delta=9.26(\mathrm{~s}, 1 \mathrm{H}$, 
pyridine), 8.68 (d, $J=5.83 \mathrm{~Hz}, 1 \mathrm{H}$, pyridine), $8.38(\mathrm{~d}, J=5.83 \mathrm{~Hz}$, $1 \mathrm{H}$, pyridine), 7.77-7.94 (m, 5H, phenyl, NH), 7.47-7.70 (m, 5H, phenyl), $7.41(\mathrm{~s}, 1 \mathrm{H}, \mathrm{NH}), 6.62-7.09\left(\mathrm{~m}, 1 \mathrm{H}, \mathrm{CHF}_{2}\right), 5.01(\mathrm{dt}, J=$ 4.69, $8.05 \mathrm{~Hz}, 1 \mathrm{H}, \mathrm{CH}-\mathrm{C}(\mathrm{O})), 1.97-2.16\left(\mathrm{~m}, 2 \mathrm{H}, \mathrm{CH}_{2}\right), 0.96(\mathrm{t}, J=$ $\left.7.35 \mathrm{~Hz}, 3 \mathrm{H}, \mathrm{CH}_{3}\right) .{ }^{19} \mathrm{~F}$ NMR $\left(377 \mathrm{MHz}, \mathrm{DMSO}-d_{6}\right): \delta=-107.41$ $(\mathrm{d}, J=54.93 \mathrm{~Hz}, 2 \mathrm{~F})$. HRMS (ESI, $\left.[\mathrm{M}+\mathrm{H}]^{+}\right)$: calcd for $\mathrm{C}_{26} \mathrm{H}_{22} \mathrm{~F}_{2} \mathrm{~N}_{5} \mathrm{O}$, 458.1793; found, 458.1792. $[\alpha]_{\mathrm{D}}^{20}+32.1 \pm 0.62(c=1$, DMSO).

(2R)-2-(\{3-Cyano-2-[2'-(trifluoromethyl)biphenyl-4-yl]-1,7-naphthyridin-4-yl\}amino)butanamide (40). Compound 40 (58 mg, 38\%) was prepared analogously to 17 , from 12 and [2-(trifluoromethyl)phenyl]boronic acid (commercially available, CAS-RN: [1423-27-4]). LC-MS (acidic conditions): ${ }^{t} \mathrm{R}=1.17 \mathrm{~min}$. MS $\left(\mathrm{ESI}^{+}\right): \mathrm{m} / z=476.2$ $[\mathrm{M}+\mathrm{H}]^{+} .{ }^{1} \mathrm{H}$ NMR (DMSO- $\left.d_{6}\right) \delta: 9.27(\mathrm{~s}, 1 \mathrm{H}$, pyridine), $8.68(\mathrm{~d}, J$ $=5.8 \mathrm{~Hz}, 1 \mathrm{H}), 8.37(\mathrm{~d}, J=5.8 \mathrm{~Hz}, 1 \mathrm{H}), 7.74-7.91(\mathrm{~m}, 6 \mathrm{H}$, phenyl, $\mathrm{NH}), 7.60-7.71(\mathrm{~m}, 1 \mathrm{H}$, phenyl), 7.47-7.53 (m, 3H, phenyl, $\mathrm{NH})$, $7.41(\mathrm{~s}, 1 \mathrm{H}, \mathrm{NH}), 4.95-5.05(\mathrm{~m}, 1 \mathrm{H}, \mathrm{CH}-\mathrm{C}(\mathrm{O})), 1.86-2.23(\mathrm{~m}, 2 \mathrm{H}$, $\left.\mathrm{CH}_{2}\right), 0.96\left(\mathrm{t}, J=7.4 \mathrm{~Hz}, 3 \mathrm{H}, \mathrm{CH}_{3}\right) .[\alpha]_{\mathrm{D}}^{20}+30.5 \pm 0.18(c=1$, DMSO).

(2R)-2-(\{3-Cyano-2-[2'-(hydroxymethyl)biphenyl-4-yl]-1,7-naphthyridin-4-yl\}amino)butanamide (41). Compound 41 (67 mg, 52\%) was prepared analogously to 17 , from 12 and [2-(hydroxymethyl)phenyl]boronic acid (commercially available, CAS-RN: [87199-142]). LC-MS (acidic conditions): ${ }^{t} \mathrm{R}=0.97 \mathrm{~min}$. $\mathrm{MS}\left(\mathrm{ESI}^{+}\right): \mathrm{m} / z=$ $438.5[\mathrm{M}+\mathrm{H}]^{+} .{ }^{1} \mathrm{H}$ NMR $\left(400 \mathrm{MHz}\right.$, DMSO- $\left.d_{6}\right): \delta=9.26(\mathrm{~s}, 1 \mathrm{H}$, pyridine), $8.67(\mathrm{~d}, J=5.83 \mathrm{~Hz}, 1 \mathrm{H}$, pyridine), $8.37(\mathrm{~d}, J=5.83 \mathrm{~Hz}$, $1 \mathrm{H}$, pyridine), $7.78-7.90(\mathrm{~m}, 4 \mathrm{H}$, phenyl, $\mathrm{NH}), 7.62(\mathrm{dd}, J=0.89$, $7.48 \mathrm{~Hz}, 1 \mathrm{H}$, phenyl), 7.52-7.58 (m, 2H, phenyl), 7.29-7.48 $(\mathrm{m}, 4 \mathrm{H}$, phenyl, NH), $5.22(\mathrm{t}, J=5.32 \mathrm{~Hz}, 1 \mathrm{H}, \mathrm{OH}), 5.00(\mathrm{dt}, J=4.69,8.05$ $\mathrm{Hz}, 1 \mathrm{H}, \mathrm{CH}-\mathrm{C}(\mathrm{O})), 4.47\left(\mathrm{~d}, J=5.32 \mathrm{~Hz}, 2 \mathrm{H}, \mathrm{OCH}_{2}\right), 1.95-2.18(\mathrm{~m}$, $\left.2 \mathrm{H}, \mathrm{CH}_{2}\right), 0.96\left(\mathrm{t}, J=7.22 \mathrm{~Hz}, 3 \mathrm{H}, \mathrm{CH}_{3}\right)$. HRMS (ESI, $\left.[\mathrm{M}+\mathrm{H}]^{+}\right)$: calcd for $\mathrm{C}_{26} \mathrm{H}_{24} \mathrm{~N}_{5} \mathrm{O}_{2}, 438.1931$; found, 438.1928. $[\alpha]_{\mathrm{D}}^{20}+34.5 \pm 0.57$ $(c=1, \mathrm{DMSO})$.

(2R)-2-(\{3-Cyano-2-[2'-(methoxymethyl)biphenyl-4-yl]-1,7naphthyridin-4-yl\}amino)butanamide (42). Compound 42 (100 $\mathrm{mg}, 76 \%$ ) was prepared analogously to 32 , from 12 and [2(methoxymethyl)phenyl]boronic acid (CAS-RN: [126617-98-9]). LC-MS (acidic conditions): ${ }^{t} \mathrm{R}=1.12 \mathrm{~min} . \mathrm{MS}\left(\mathrm{ESI}^{+}\right): \mathrm{m} / z=$ $452.3[\mathrm{M}+\mathrm{H}]^{+} .{ }^{1} \mathrm{H}$ NMR $\left(400 \mathrm{MHz}, \mathrm{DMSO}-d_{6}\right): \delta=9.26(\mathrm{~s}, 1 \mathrm{H}$, pyridine), $8.67(\mathrm{~d}, J=5.83 \mathrm{~Hz}, 1 \mathrm{H}$, pyridine $), 8.38(\mathrm{~d}, J=5.83 \mathrm{~Hz}$, $1 \mathrm{H}$, pyridine $), 7.78-7.91(\mathrm{~m}, 4 \mathrm{H}$, phenyl, $\mathrm{NH}), 7.50-7.60(\mathrm{~m}, 3 \mathrm{H}$, phenyl), 7.36-7.47 (m, 4H, phenyl, NH), 4.96-5.04 (m, $1 \mathrm{H}, \mathrm{CH}-$ $\mathrm{C}(\mathrm{O})), 4.35\left(\mathrm{~s}, 2 \mathrm{H}, \mathrm{OCH}_{2}\right), 3.26\left(\mathrm{~s}, 3 \mathrm{H}, \mathrm{OCH}_{3}\right), 1.96-2.17(\mathrm{~m}, 2 \mathrm{H}$, $\left.\mathrm{CH}_{2}\right), 0.96\left(\mathrm{t}, J=7.22 \mathrm{~Hz}, 3 \mathrm{H}, \mathrm{CH}_{3}\right)$. HRMS $\left(\mathrm{ESI},[\mathrm{M}+\mathrm{H}]^{+}\right)$: calcd for $\mathrm{C}_{27} \mathrm{H}_{26} \mathrm{~N}_{5} \mathrm{O}_{2}$, 452.2087; found, 452.2085. $[\alpha]_{\mathrm{D}}^{20}+36.6 \pm 0.45(c=$ 1 , DMSO).

(2R)-2-\{[3-Cyano-2-(3'-fluorobiphenyl-4-yl)-1,7-naphthyridin-4yl]amino\}butanamide (43). Compound 43 (51 $\mathrm{mg}, 49 \%)$ was prepared analogously to 32, from 12 and (3-fluorophenyl)boronic acid (commercially available, CAS-RN: [768-35-4]). LC-MS (acidic conditions): ${ }^{t} \mathrm{R}=1.15 \mathrm{~min}$. $\mathrm{MS}\left(\mathrm{ESI}^{+}\right): m / z=426.4[\mathrm{M}+\mathrm{H}]^{+} .{ }^{1} \mathrm{H}$ NMR ( $\left.400 \mathrm{MHz}, \mathrm{DMSO}-d_{6}\right): \delta=9.25(\mathrm{~s}, 1 \mathrm{H}$, pyridine), 8.67 (d, $J=$ $5.83 \mathrm{~Hz}, 1 \mathrm{H}$, pyridine), $8.37(\mathrm{~d}, J=5.58 \mathrm{~Hz}, 1 \mathrm{H}$, pyridine $), 7.79-7.91$ (m, 6H, phenyl, NH), 7.67 (m, $1 \mathrm{H}$, phenyl), 7.64 (m, $1 \mathrm{H}$, phenyl), $7.52-7.60(\mathrm{~m}, 1 \mathrm{H}$, phenyl), $7.41(\mathrm{~s}, 1 \mathrm{H}, \mathrm{NH}), 7.26(\mathrm{t}, J=8.21 \mathrm{~Hz}$, $1 \mathrm{H}$, phenyl), $4.99(\mathrm{dt}, J=4.69,8.17 \mathrm{~Hz}, 1 \mathrm{H}, \mathrm{CH}-\mathrm{C}(\mathrm{O})), 1.96-2.17$ $\left(\mathrm{m}, 2 \mathrm{H}, \mathrm{CH}_{2}\right), 0.96\left(\mathrm{t}, J=7.35 \mathrm{~Hz}, 3 \mathrm{H}, \mathrm{CH}_{3}\right) .{ }^{19} \mathrm{~F} \mathrm{NMR}(377 \mathrm{MHz}$ DMSO- $\left.d_{6}\right): \delta=-112.98(\mathrm{dt}, J=4.01,7.73 \mathrm{~Hz}, 1 \mathrm{~F})$. HRMS (ESI, [M $\left.+\mathrm{H}]^{+}\right)$: calcd for $\mathrm{C}_{25} \mathrm{H}_{21} \mathrm{FN}_{5} \mathrm{O}$, 426.1731; found, 426.1731. $[\alpha]_{\mathrm{D}}^{20}$ $+43.4 \pm 0.38(c=1$, DMSO $)$.

(2R)-2-\{[2-(3'-Chlorobiphenyl-4-yl)-3-cyano-1,7-naphthyridin-4yl]amino\}butanamide (44). Compound $44(34 \mathrm{mg}, 25 \%)$ was prepared analogously to 32, from 12 and (3-chlorophenyl)boronic acid (commercially available, CAS-RN: [63503-60-6]). LC-MS (acidic conditions): ${ }^{t} \mathrm{R}=1.22 \mathrm{~min}$. MS $\left(\mathrm{ESI}^{+}\right): \mathrm{m} / z=442.3[\mathrm{M}+$ $\mathrm{H}]^{+}$. ${ }^{1} \mathrm{H}$ NMR (400 MHz, DMSO- $d_{6}$ ): $\delta=9.27$ (br s, $1 \mathrm{H}$, pyridine), 8.68 (br s, $1 \mathrm{H}$, pyridine), 8.38 (br d, $J=5.58 \mathrm{~Hz}, 1 \mathrm{H}$, pyridine), 7.75-7.92 (m, 8H, phenyl, $\mathrm{NH}), 7.46-7.71(\mathrm{~m}, 2 \mathrm{H}$, phenyl), $7.41(\mathrm{~s}$, $1 \mathrm{H}, \mathrm{NH}), 4.96-5.03(\mathrm{~m}, 1 \mathrm{H}, \mathrm{CH}-\mathrm{C}(\mathrm{O})), 1.96-2.17\left(\mathrm{~m}, 2 \mathrm{H}, \mathrm{CH}_{2}\right)$, $0.96\left(\mathrm{t}, J=7.35 \mathrm{~Hz}, 3 \mathrm{H}, \mathrm{CH}_{3}\right)$. HRMS (ESI, $[\mathrm{M}+\mathrm{H}]^{+}$): calcd for $\mathrm{C}_{25} \mathrm{H}_{21} \mathrm{ClN}_{5} \mathrm{O}$, 442.1436; found, 442.1434 .

(2R)-2-\{[3-Cyano-2-(3'-methylbiphenyl-4-yl)-1,7-naphthyridin-4yl]amino\}butanamide (45). Compound 45 (26 mg, 20\%) was prepared analogously to 32, from 12 and (3-methylphenyl)boronic acid (commercially available, CAS-RN: [17933-03-8]). LC-MS (acidic conditions): ${ }^{t} \mathrm{R}=1.20 \mathrm{~min}$. $\mathrm{MS}\left(\mathrm{ESI}^{+}\right): \mathrm{m} / z=422.2[\mathrm{M}+$ $\mathrm{H}]^{+} .{ }^{1} \mathrm{H}$ NMR $\left(400 \mathrm{MHz}, \mathrm{DMSO}-d_{6}\right): \delta=9.27$ (br s, $1 \mathrm{H}$, pyridine), 8.68 (br s, $1 \mathrm{H}$, pyridine), 8.38 (br d, $J=5.07 \mathrm{~Hz}, 1 \mathrm{H}$, pyridine), 7.77-7.91 (m, 6H, phenyl, $\mathrm{NH}), 7.46-7.67(\mathrm{~m}, 2 \mathrm{H}$, phenyl, $\mathrm{NH})$, 7.34-7.46 (m, 2H, phenyl), $7.24(\mathrm{~d}, J=7.35 \mathrm{~Hz}, 1 \mathrm{H}$, phenyl), 4.96$5.03(\mathrm{~m}, 1 \mathrm{H}, \mathrm{CH}-\mathrm{C}(\mathrm{O})), 2.41\left(\mathrm{~s}, 3 \mathrm{H}, \mathrm{CH}_{3}\right), 1.96-2.18(\mathrm{~m}, 2 \mathrm{H}$, $\left.\mathrm{CH}_{2}\right), 0.96\left(\mathrm{t}, J=7.35 \mathrm{~Hz}, 3 \mathrm{H}, \mathrm{CH}_{3}\right)$. HRMS (ESI, $\left.[\mathrm{M}+\mathrm{H}]^{+}\right)$: calcd for $\mathrm{C}_{26} \mathrm{H}_{24} \mathrm{~N}_{5} \mathrm{O}$, 422.1982; found, 422.1979. $[\alpha]_{\mathrm{D}}^{20}+30.1 \pm 6.24(c=$ 1 , DMSO).

(2R)-2-\{[3-Cyano-2-(3'-methoxybiphenyl-4-yl)-1,7-naphthyridin4-yl]amino\}butanamide (46). Compound $46(139 \mathrm{mg}, 64 \%)$ was prepared analogously to 17 , from 12 and (3-methoxyphenyl)boronic acid (commercially available, CAS-RN: [10365-98-7]). LC-MS (acidic conditions): ${ }^{t} \mathrm{R}=1.14 \mathrm{~min}$. $\mathrm{MS}\left(\mathrm{ESI}^{+}\right): \mathrm{m} / z=438.6[\mathrm{M}+$ $\mathrm{H}]^{+}$. ${ }^{1} \mathrm{H}$ NMR (400 MHz, DMSO- $d_{6}$ ): $\delta=9.25$ (s, $1 \mathrm{H}$, pyridine), $8.67(\mathrm{~d}, J=5.83 \mathrm{~Hz}, 1 \mathrm{H}$, pyridine $), 8.37(\mathrm{~d}, J=5.58 \mathrm{~Hz}, 1 \mathrm{H}$, pyridine $), 7.79-7.90(\mathrm{~m}, 6 \mathrm{H}$, phenyl, $\mathrm{NH}), 7.39-7.45(\mathrm{~m}, 2 \mathrm{H}$, phenyl, NH), 7.32-7.36 (m, 1H, phenyl), 7.30 (s, 1H, phenyl), 6.99 (d, $J=7.87 \mathrm{~Hz}, 1 \mathrm{H}$, phenyl), $4.99(\mathrm{dt}, J=4.82,8.11 \mathrm{~Hz}, 1 \mathrm{H}, \mathrm{CH}-$ $\mathrm{C}(\mathrm{O})), 3.86\left(\mathrm{~s}, 3 \mathrm{H}, \mathrm{OCH}_{3}\right), 1.96-2.17\left(\mathrm{~m}, 2 \mathrm{H}, \mathrm{CH}_{2}\right), 0.96(\mathrm{t}, J=$ $7.35 \mathrm{~Hz}, 3 \mathrm{H}, \mathrm{CH}_{3}$ ). HRMS (ESI, $[\mathrm{M}+\mathrm{H}]^{+}$): calcd for $\mathrm{C}_{26} \mathrm{H}_{24} \mathrm{~N}_{5} \mathrm{O}_{2}$, 438.1931; found, 438.1929. [ $\alpha]_{\mathrm{D}}^{20}+43.3 \pm 0.29(c=1$, DMSO).

(2R)-2-(\{3-Cyano-2-[3'-(hydroxymethyl)biphenyl-4-yl]-1,7-naphthyridin-4-yl\}amino)-butanamide (47). Compound 47 (62 mg, $56 \%$ ) was prepared analogously to 17 , from 12 and [3(hydroxymethyl)phenyl]boronic acid (commercially available, CAS$\mathrm{RN}$ : [87199-15-3]). LC-MS (acidic conditions): ${ }^{t} \mathrm{R}=0.85 \mathrm{~min} . \mathrm{MS}$ $\left(\mathrm{ESI}^{+}\right): m / z=438.2[\mathrm{M}+\mathrm{H}]^{+} .{ }^{1} \mathrm{H}$ NMR $\left(\mathrm{DMSO}-d_{6}\right) \delta: 9.26(\mathrm{~s}, 1 \mathrm{H}$, pyridine $), 8.67(\mathrm{~d}, J=5.7 \mathrm{~Hz}, 1 \mathrm{H}$, pyridine $), 8.37(\mathrm{~d}, J=6.0 \mathrm{~Hz}, 1 \mathrm{H}$, pyridine), 7.87-7.92 ( $\mathrm{m}, 2 \mathrm{H}$, phenyl), 7.77-7.86 (m, 4H, phenyl, $\mathrm{NH}), 7.62-7.73(\mathrm{~m}, 2 \mathrm{H}$, phenyl, NH), $7.47(\mathrm{t}, J=7.6 \mathrm{~Hz}, 1 \mathrm{H}$, phenyl), 7.35-7.43 (m, $2 \mathrm{H}$, phenyl), $5.29(\mathrm{t}, J=5.8 \mathrm{~Hz}, 1 \mathrm{H}, \mathrm{OH})$, $5.00(\mathrm{td}, J=8.2,4.7 \mathrm{~Hz}, 1 \mathrm{H}, \mathrm{CH}-\mathrm{C}(\mathrm{O})), 4.61(\mathrm{~d}, J=5.7 \mathrm{~Hz}, 2 \mathrm{H}$, $\left.\mathrm{CH}_{2}-\mathrm{O}\right), 1.94-2.20\left(\mathrm{~m}, 2 \mathrm{H}, \mathrm{CH}_{2}\right), 0.96\left(\mathrm{t}, J=7.4 \mathrm{~Hz}, 3 \mathrm{H}, \mathrm{CH}_{3}\right)$.

(2R)-2-\{[3-Cyano-2-(4'-fluorobiphenyl-4-yl)-1,7-naphthyridin-4yl]amino\}butanamide (48). Compound 48 (42 $\mathrm{mg}, 38 \%)$ was prepared analogously to 17 , from 12 and (4-fluorophenyl)boronic acid (commercially available, CAS-RN: [1765-93-1]). LC-MS (acidic conditions): ${ }^{t} \mathrm{R}=1.15 \mathrm{~min}$. MS $\left(\mathrm{ESI}^{+}\right): m / z=426.4[\mathrm{M}+\mathrm{H}]^{+} .{ }^{1} \mathrm{H}$ NMR (400 MHz, DMSO- $\left.d_{6}\right): \delta=9.26$ (br s, $1 \mathrm{H}$, pyridine), $8.68(\mathrm{br}$ s, $1 \mathrm{H}$, pyridine), 8.38 (br d, $J=4.82 \mathrm{~Hz}, 1 \mathrm{H}$, pyridine), 7.77-7.92 (m, $8 \mathrm{H}$, phenyl, NH), 7.31-7.43 (m, 3H, phenyl, $\mathrm{NH}), 4.96-5.03(\mathrm{~m}$, $1 \mathrm{H}, \mathrm{CH}-\mathrm{C}(\mathrm{O})), 1.96-2.17\left(\mathrm{~m}, 2 \mathrm{H}, \mathrm{CH}_{2}\right), 0.96(\mathrm{t}, J=7.22 \mathrm{~Hz}, 3 \mathrm{H}$, $\left.\mathrm{CH}_{3}\right) .{ }^{19} \mathrm{~F}$ NMR $\left(377 \mathrm{MHz}\right.$, DMSO- $\left.d_{6}\right): \delta=-120.25$ to $-106.37(\mathrm{~m}$, $1 F)$. HRMS (ESI, $\left.[\mathrm{M}+\mathrm{H}]^{+}\right)$: calcd for $\mathrm{C}_{25} \mathrm{H}_{21} \mathrm{FN}_{5} \mathrm{O}, 426.1731$; found, 426.1725. $[\alpha]_{\mathrm{D}}^{20}+43.7 \pm 2.81(c=1$, DMSO $)$.

(2R)-2-\{[2-(4'-Chlorobiphenyl-4-yl)-3-cyano-1,7-naphthyridin-4yl]amino\}butanamide (49). Compound $49(30 \mathrm{mg}, 14 \%)$ was prepared analogously to 17 , from 12 and (4-chlorophenyl)boronic acid (commercially available, CAS-RN: [1679-18-1]). LC-MS (acidic conditions): ${ }^{t} \mathrm{R}=1.22 \mathrm{~min}$. MS $\left.\left(\mathrm{ESI}^{+}\right): \mathrm{m} / z=442.3[\mathrm{M}+\mathrm{H}]\right]^{+} .{ }^{1} \mathrm{H}$ NMR (400 MHz, DMSO- $\left.d_{6}\right): \delta=9.25$ (br s, $1 \mathrm{H}$, pyridine), 8.67 (br $\mathrm{s}, 1 \mathrm{H}$, pyridine), 8.37 (br s, $1 \mathrm{H}$, pyridine), $7.71-7.96(\mathrm{~m}, 8 \mathrm{H}$, phenyl, $\mathrm{NH}), 7.57$ (br d, $J=8.11 \mathrm{~Hz}, 2 \mathrm{H}$, phenyl), 7.40 (br s, $1 \mathrm{H}, \mathrm{NH}), 4.98$ (br s, $1 \mathrm{H}, \mathrm{CH}-\mathrm{C}(\mathrm{O})), 1.92-2.17\left(\mathrm{~m}, 2 \mathrm{H}, \mathrm{CH}_{2}\right), 0.95$ (br s, $3 \mathrm{H}$, $\mathrm{CH}_{3}$ ). HRMS (ESI, $[\mathrm{M}+\mathrm{H}]^{+}$): calcd for $\mathrm{C}_{25} \mathrm{H}_{21} \mathrm{ClN}_{5} \mathrm{O}, 442.1436$; found, 442.1432 .

(2R)-2-\{[3-Cyano-2-(4'-methoxybiphenyl-4-yl)-1,7-naphthyridin4-yl]amino\}butanamide (50). Compound $50(111 \mathrm{mg}, 69 \%)$ was prepared analogously to 17 , from 12 and (4-methoxyphenyl)boronic acid (commercially available, CAS-RN: [5720-07-0]). LC-MS (acidic conditions): ${ }^{t} \mathrm{R}=1.12 \mathrm{~min}$. MS $\left(\mathrm{ESI}^{+}\right): m / z=438.6[\mathrm{M}+\mathrm{H}]^{+} .{ }^{1} \mathrm{H}$ NMR (400 MHz, DMSO- $\left.d_{6}\right): \delta=9.25(\mathrm{~s}, 1 \mathrm{H}$, pyridine), $8.66(\mathrm{~d}, J=$ $5.58 \mathrm{~Hz}, 1 \mathrm{H}$, pyridine), 8.36 (d, $J=5.58 \mathrm{~Hz}, 1 \mathrm{H}$, pyridine), $7.84-7.89$ 
(m, 2H, phenyl), $7.83(\mathrm{~s}, 1 \mathrm{H}, \mathrm{NH}), 7.78-7.82(\mathrm{~m}, 3 \mathrm{H}$, phenyl, $\mathrm{NH})$, $7.73(\mathrm{~d}, J=8.87 \mathrm{~Hz}, 2 \mathrm{H}$, phenyl), $7.41(\mathrm{~s}, 1 \mathrm{H}, \mathrm{NH}), 7.08(\mathrm{~d}, J=7.92$ $\mathrm{Hz}, 2 \mathrm{H}$, phenyl), 4.99 (dt, $J=4.69,8.05 \mathrm{~Hz}, 1 \mathrm{H}, \mathrm{CH}-\mathrm{C}(\mathrm{O})), 3.82$ (s, $\left.3 \mathrm{H}, \mathrm{OCH}_{3}\right), 1.96-2.17\left(\mathrm{~m}, 2 \mathrm{H}, \mathrm{CH}_{2}\right), 0.96(\mathrm{t}, J=7.35 \mathrm{~Hz}, 3 \mathrm{H}$, $\mathrm{CH}_{3}$ ). HRMS (ESI, $[\mathrm{M}+\mathrm{H}]^{+}$): calcd for $\mathrm{C}_{26} \mathrm{H}_{24} \mathrm{~N}_{5} \mathrm{O}_{2}, 438.1931$; found, 438.1928. $[\alpha]_{\mathrm{D}}^{20}+48.2 \pm 0.44(c=1, \mathrm{DMSO})$.

(2R)-2-(\{3-Cyano-2-[4-(3-methylpyridin-2-yl)phenyl]-1,7-naphthyridin-4-yl\}amino)butanamide (51). Step 1: To a solution of 12 $(1.19 \mathrm{~g}, 2.9 \mathrm{mmol})$ in anhydrous 1,4-dioxane $(79 \mathrm{~mL})$ were added bis(pinacolato)diboron $(1.47 \mathrm{~g}, 5.8 \mathrm{mmol})$ and potassium acetate (1 g, $10.15 \mathrm{mmol}) \cdot \mathrm{PdCl}_{2}(\mathrm{dppf})(212 \mathrm{mg}, 0.29 \mathrm{mmol})$ was added and the reaction mixture was stirred at $90{ }^{\circ} \mathrm{C}$ for $16 \mathrm{~h}$ under nitrogen. DMF $(30 \mathrm{~mL})$, bis(pinacolato)diboron (1.47 g, $5.8 \mathrm{mmol})$, and potassium acetate $(1 \mathrm{~g}, 10.15 \mathrm{mmol})$ were added and the reaction mixture was stirred at $90{ }^{\circ} \mathrm{C}$ for $8 \mathrm{~h}$. Concentration under reduced pressure and purification of the resulting residue by flash column chromatography (eluent: $n$-hexane/EtOAc gradient) gave [4-(4$\{[(2 R)$-1-amino-1-oxobutan-2-yl]amino $\}$-3-cyano-1,7-naphthyridin-2yl)phenyl]boronic acid (892 mg, 82\%). Step 2: Compound 51 (4 mg, $4 \%)$ was prepared analogously to 17 , from $[4-(4-\{[(2 R)-1$-amino- 1 oxobutan-2-yl]amino\}-3-cyano-1,7-naphthyridin-2-yl)phenyl]boronic acid and 2-chloro-3-methylpyridine (commercially available, CAS$\mathrm{RN}:[18368-76-8])$. LC-MS (basic conditions): ${ }^{t} \mathrm{R}=0.98 \mathrm{~min}$. MS $\left(\mathrm{ESI}^{+}\right): m / z=423.5[\mathrm{M}+\mathrm{H}]^{+} .{ }^{1} \mathrm{H}$ NMR $\left(400 \mathrm{MHz}, \mathrm{DMSO}-d_{6}\right): \delta=$ $9.26(\mathrm{~s}, 1 \mathrm{H}$, pyridine $), 8.68(\mathrm{~d}, J=5.83 \mathrm{~Hz}, 1 \mathrm{H}$, pyridine $), 8.50-8.56$ (m, $1 \mathrm{H}$, pyridine), $8.34-8.42(\mathrm{~m}, 1 \mathrm{H}, \mathrm{NH}), 7.82-7.90(\mathrm{~m}, 3 \mathrm{H}$, pyridine, phenyl), $7.75-7.82(\mathrm{~m}, 2 \mathrm{H}, \mathrm{NH}$, pyridine $), 7.72(\mathrm{~d}, J=8.36$ $\mathrm{Hz}, 2 \mathrm{H}$, phenyl), 7.38-7.44 (m, $1 \mathrm{H}, \mathrm{NH}), 7.35$ (dd, $J=7.60,4.82$ $\mathrm{Hz}, 1 \mathrm{H}$, pyridine $), 4.92-5.06(\mathrm{~m}, 1 \mathrm{H}), 2.40(\mathrm{~m}, 3 \mathrm{H}), 1.96-2.18(\mathrm{~m}$, $2 \mathrm{H}), 0.96(\mathrm{~m}, 3 \mathrm{H})$.

(2R)-2-(\{3-Cyano-2-[4-(4-methylpyridin-3-yl)phenyl]-1,7-naphthyridin-4-yl\}amino)butanamide (52). Compound 52 (50 mg, 43\%) was prepared analogously to 17, from 12 and (4-methylpyridin-3yl)boronic acid (commercially available, CAS-RN: [148546-82-1]). LC-MS (basic conditions): ${ }^{t} \mathrm{R}=0.94 \mathrm{~min}$. MS $\left(\mathrm{ESI}^{+}\right): \mathrm{m} / z=423.5$ $[\mathrm{M}+\mathrm{H}]^{+} .{ }^{1} \mathrm{H}$ NMR $\left(400 \mathrm{MHz}\right.$, DMSO- $\left.d_{6}\right): \delta=9.26(\mathrm{~s}, 1 \mathrm{H}$, pyridine), 8.68 (d, $J=5.83 \mathrm{~Hz}, 1 \mathrm{H}$, pyridine), $8.46-8.49(\mathrm{~m}, 2 \mathrm{H}, \mathrm{NH}$, pyridine), $8.38(\mathrm{~d}, J=6.08 \mathrm{~Hz}, 1 \mathrm{H}$, pyridine $), 7.91(\mathrm{~d}, J=8.11 \mathrm{~Hz}$, $2 \mathrm{H}$, phenyl), $7.85(\mathrm{br} \mathrm{d}, J=8.36 \mathrm{~Hz}, 1 \mathrm{H}$, pyridine), $7.80(\mathrm{~s}, 1 \mathrm{H}, \mathrm{NH})$, $7.59(\mathrm{~d}, J=8.36 \mathrm{~Hz}, 2 \mathrm{H}$, phenyl), $7.41(\mathrm{~s}, 1 \mathrm{H}, \mathrm{NH}), 7.39(\mathrm{~d}, J=5.07$ $\mathrm{Hz}, 1 \mathrm{H}$, pyridine ), $5.00(\mathrm{dt}, J=5.07,7.98 \mathrm{~Hz}, 1 \mathrm{H}, \mathrm{CH}-\mathrm{C}(\mathrm{O})), 2.34$ $\left(\mathrm{s}, 3 \mathrm{H}, \mathrm{CH}_{3}\right), 1.96-2.18\left(\mathrm{~m}, 2 \mathrm{H}, \mathrm{CH}_{2}\right), 0.96(\mathrm{t}, J=7.22 \mathrm{~Hz}, 3 \mathrm{H}$, $\left.\mathrm{CH}_{3}\right)$.

(2R)-2-(\{3-Cyano-2-[4-(3-methylpyridin-4-yl)phenyl]-1,7-naphthyridin-4-yl\}amino)butanamide (53). Compound 53 (58 mg, 46\%) was prepared analogously to 17 , from 12 and (3-methylpyridin-4yl)boronic acid (commercially available, CAS-RN: [894808-72-1]). LC-MS (basic conditions): ${ }^{t} \mathrm{R}=0.93 \mathrm{~min}$. MS $\left(\mathrm{ESI}^{+}\right): \mathrm{m} / z=423.6$ $[\mathrm{M}+\mathrm{H}]^{+} .{ }^{1} \mathrm{H}$ NMR $\left(400 \mathrm{MHz}\right.$, DMSO- $\left.d_{6}\right): \delta=9.26(\mathrm{~s}, 1 \mathrm{H}$, pyridine ), $8.68(\mathrm{~d}, J=5.83 \mathrm{~Hz}, 1 \mathrm{H}$, pyridine), 8.55 (s, $1 \mathrm{H}$, pyridine), $8.50(\mathrm{~d}, J=4.82 \mathrm{~Hz}, 1 \mathrm{H}, \mathrm{NH}), 8.38(\mathrm{~d}, J=5.58 \mathrm{~Hz}, 1 \mathrm{H}$, pyridine $)$, $7.88-7.94(\mathrm{~m}, 2 \mathrm{H}$, phenyl), $7.86(\mathrm{~d}, J=8.62 \mathrm{~Hz}, 1 \mathrm{H}$, pyridine $), 7.80$ (s, $1 \mathrm{H}, \mathrm{NH}), 7.60(\mathrm{~d}, J=7.71 \mathrm{~Hz}, 2 \mathrm{H}$, phenyl), $7.41(\mathrm{~s}, 1 \mathrm{H}, \mathrm{NH})$, $7.34(\mathrm{~d}, J=4.82 \mathrm{~Hz}, 1 \mathrm{H}$, pyridine), $5.00(\mathrm{dt}, J=4.82,8.11 \mathrm{~Hz}, 1 \mathrm{H}$, CH-C $(\mathrm{O})), 2.32\left(\mathrm{~s}, 3 \mathrm{H}, \mathrm{CH}_{3}\right), 1.96-2.17\left(\mathrm{~m}, 2 \mathrm{H}, \mathrm{CH}_{2}\right), 0.96(\mathrm{t}, J=$ $\left.7.35 \mathrm{~Hz}, 3 \mathrm{H}, \mathrm{CH}_{3}\right) .[\alpha]_{\mathrm{D}}^{20}+30.8 \pm 0.56(c=1, \mathrm{DMSO})$.

(2R)-2-(\{3-Cyano-2-[4-(2-methylpyridin-3-yl)phenyl]-1,7-naphthyridin-4-yl\}amino)butanamide (54). Compound $54(11 \mathrm{mg}, 10 \%)$ was prepared analogously to 17, from 12 and (2-methylpyridin-3yl)boronic acid (commercially available, CAS-RN: [899436-71-6]). LC-MS (basic conditions): ${ }^{t} \mathrm{R}=0.93 \mathrm{~min}$. MS $\left(\mathrm{ESI}^{+}\right): \mathrm{m} / z=423.5$ $[\mathrm{M}+\mathrm{H}]]^{+} .{ }^{1} \mathrm{H}$ NMR $\left(400 \mathrm{MHz}\right.$, DMSO- $\left.d_{6}\right): \delta=9.26(\mathrm{~s}, 1 \mathrm{H}$, pyridine), 8.67 (d, $J=5.83 \mathrm{~Hz}, 1 \mathrm{H}$, pyridine), 8.51 (dd, $J=1.77$, 4.82 $\mathrm{Hz}, 1 \mathrm{H}$, pyridine), 8.37 (d, $J=5.83 \mathrm{~Hz}, 1 \mathrm{H}$, pyridine), 7.87-7.93 (m, $2 \mathrm{H}$, phenyl), $7.85(\mathrm{~d}, J=8.36 \mathrm{~Hz}, 1 \mathrm{H}, \mathrm{NH}), 7.80(\mathrm{~s}, 1 \mathrm{H}, \mathrm{NH}), 7.71$ (dd, $J=1.77,7.86 \mathrm{~Hz}, 1 \mathrm{H}$, pyridine), $7.58(\mathrm{~d}, J=7.74 \mathrm{~Hz}, 2 \mathrm{H}$, phenyl), $7.42(\mathrm{~s}, 1 \mathrm{H}, \mathrm{NH}), 7.35$ (dd, $J=4.82,7.60 \mathrm{~Hz}, 1 \mathrm{H}$, pyridine), $5.00(\mathrm{dt}, J=4.69,8.05 \mathrm{~Hz}, 1 \mathrm{H}, \mathrm{CH}-\mathrm{C}(\mathrm{O})), 1.97-2.17\left(\mathrm{~m}, 2 \mathrm{H}, \mathrm{CH}_{2}\right)$, $0.96\left(\mathrm{t}, J=7.35 \mathrm{~Hz}, 3 \mathrm{H}, \mathrm{CH}_{3}\right)$; aromatic methyl group under solvent signal. HRMS (ESI, $[\mathrm{M}+\mathrm{H}]^{+}$): calcd for $\mathrm{C}_{25} \mathrm{H}_{23} \mathrm{~N}_{6} \mathrm{O}$, 423.1934; found, 423.1932.

(2R)-2-\{[3-Cyano-2-(4'-fluoro-2'-methoxybiphenyl-4-yl)-1,7naphthyridin-4-yl]amino\}butanamide (55). Compound $55(40 \mathrm{mg}$, $36 \%$ ) was prepared analogously to 17 , from 12 and (4-fluoro-2methoxyphenyl)boronic acid (CAS-RN: [179899-07-1]). LC-MS (basic conditions): ${ }^{t} \mathrm{R}=1.15 \mathrm{~min}$. $\mathrm{MS}\left(\mathrm{ESI}^{+}\right): \mathrm{m} / z=456.4[\mathrm{M}+$ $\mathrm{H}]^{+} .{ }^{1} \mathrm{H}$ NMR (400 MHz, DMSO- $\left.d_{6}\right): \delta=9.24$ (s, $1 \mathrm{H}$, pyridine), $8.66(\mathrm{~d}, J=5.83 \mathrm{~Hz}, 1 \mathrm{H}$, pyridine $), 8.37(\mathrm{~d}, J=5.83 \mathrm{~Hz}, 1 \mathrm{H}$, pyridine $), 7.78-7.86(\mathrm{~m}, 4 \mathrm{H}$, phenyl, $\mathrm{NH}), 7.61(\mathrm{~d}, J=7.77 \mathrm{~Hz}, 2 \mathrm{H}$, phenyl), 7.37-7.47 ( $\mathrm{m}, 2 \mathrm{H}$, phenyl, NH), 7.08 (dd, $J=2.41,11.53$ $\mathrm{Hz}, 1 \mathrm{H}$, phenyl), $6.90(\mathrm{dt}, J=2.53,8.36 \mathrm{~Hz}, 1 \mathrm{H}$, phenyl), $4.99(\mathrm{dt}, J=$ $4.82,8.11 \mathrm{~Hz}, 1 \mathrm{H}, \mathrm{CH}-\mathrm{C}(\mathrm{O})), 3.33\left(\mathrm{~s}, 3 \mathrm{H}, \mathrm{OCH}_{3}\right), 1.96-2.15(\mathrm{~m}$, $\left.2 \mathrm{H}, \mathrm{CH}_{2}\right), 0.96\left(\mathrm{t}, J=7.35 \mathrm{~Hz}, 3 \mathrm{H}, \mathrm{CH}_{3}\right) .{ }^{19} \mathrm{~F}$ NMR $(377 \mathrm{MHz}$, DMSO- $d_{6}$ ): $\delta=-113.77$ to $-107.99(\mathrm{~m}, 1 \mathrm{~F})$. HRMS (ESI, [M + $\mathrm{H}]^{+}$): calcd for $\mathrm{C}_{26} \mathrm{H}_{23} \mathrm{FN}_{5} \mathrm{O}_{2}, 456.1837$; found, 456.1836. $[\alpha]_{\mathrm{D}}^{20}$ $+37.6 \pm 0.68(c=1$, DMSO $)$.

(2R)-2-\{[3-Cyano-2-(3'-fluoro-2'-methoxybiphenyl-4-yl)-1,7naphthyridin-4-yl]amino\}butanamide (56). Compound $56(32 \mathrm{mg}$, $29 \%$ ) was prepared analogously to 17 , from 12 and (3-fluoro-2methoxyphenyl)boronic acid (CAS-RN: [762287-59-2]). LC-MS (basic conditions): ${ }^{t} \mathrm{R}=1.16 \mathrm{~min}$. $\mathrm{MS}\left(\mathrm{ESI}^{+}\right): \mathrm{m} / z=456.4[\mathrm{M}+$ $\mathrm{H}]^{+} .{ }^{1} \mathrm{H}$ NMR (400 MHz, DMSO- $\left.d_{6}\right): \delta=9.26$ (s, $1 \mathrm{H}$, pyridine), $8.67(\mathrm{~d}, J=5.83 \mathrm{~Hz}, 1 \mathrm{H}$, pyridine $), 8.38(\mathrm{~d}, J=5.83 \mathrm{~Hz}, 1 \mathrm{H}$, pyridine), 7.78-7.91 (m, 4H, phenyl, NH), $7.68(\mathrm{~d}, J=7.69 \mathrm{~Hz}, 2 \mathrm{H}$, phenyl), 7.20-7.43 (m, 4H, phenyl, NH), $5.00(\mathrm{dt}, J=4.82,8.11 \mathrm{~Hz}$, $1 \mathrm{H}, \mathrm{CH}-\mathrm{C}(\mathrm{O})), 3.74\left(\mathrm{~d}, J=1.27 \mathrm{~Hz}, 3 \mathrm{H}, \mathrm{OCH}_{3}\right), 1.96-2.15(\mathrm{~m}, 2 \mathrm{H}$, $\left.\mathrm{CH}_{2}\right), 0.96\left(\mathrm{t}, J=7.22 \mathrm{~Hz}, 3 \mathrm{H}, \mathrm{CH}_{3}\right) .{ }^{19} \mathrm{~F}$ NMR $(377 \mathrm{MHz}$, DMSO$\left.d_{6}\right): \delta=-130.56($ br dd, $J=4.58,11.44 \mathrm{~Hz}, 1 \mathrm{~F})$. HRMS (ESI, $[\mathrm{M}+$ $\mathrm{H}]^{+}$): calcd for $\mathrm{C}_{26} \mathrm{H}_{23} \mathrm{FN}_{5} \mathrm{O}_{2}, 456.1837$; found, 456.1834. $[\alpha]_{\mathrm{D}}^{20}$ $+37.7 \pm 0.48(c=1$, DMSO $)$.

(2R)-2-\{[2-(3'-Chloro-2' -methoxybiphenyl-4-yl)-3-cyano-1,7naphthyridin-4-yl]amino\}butanamide (57). Compound 57 (34 mg, $30 \%$ ) was prepared analogously to 17 , from 12 and (3-chloro-2methoxyphenyl)boronic acid (CAS-RN: [179898-50-1]). LC-MS (basic conditions): ${ }^{t} \mathrm{R}=1.25 \mathrm{~min}$. $\mathrm{MS}\left(\mathrm{ESI}^{+}\right): \mathrm{m} / z=472.5[\mathrm{M}+$ $\mathrm{H}]^{+} .{ }^{1} \mathrm{H}$ NMR $\left(400 \mathrm{MHz}, \mathrm{DMSO}-d_{6}\right): \delta=9.26$ (s, $1 \mathrm{H}$, pyridine), $8.67(\mathrm{~d}, J=5.83 \mathrm{~Hz}, 1 \mathrm{H}$, pyridine $), 8.38(\mathrm{~d}, J=5.58 \mathrm{~Hz}, 1 \mathrm{H}$, pyridine $), 7.78-7.91(\mathrm{~m}, 4 \mathrm{H}$, phenyl, $\mathrm{NH}), 7.71(\mathrm{~d}, J=7.79 \mathrm{~Hz}, 2 \mathrm{H}$, phenyl), 7.55 (dd, $J=1.52,7.86 \mathrm{~Hz}, 1 \mathrm{H}$, phenyl), $7.38-7.48(\mathrm{~m}, 2 \mathrm{H}$, phenyl, NH), $7.28(\mathrm{t}, J=7.86 \mathrm{~Hz}, 1 \mathrm{H}$, phenyl), $5.00(\mathrm{dt}, J=4.82$, $8.11 \mathrm{~Hz}, 1 \mathrm{H}, \mathrm{CH}-\mathrm{C}(\mathrm{O})), 3.52\left(\mathrm{~s}, 3 \mathrm{H}, \mathrm{OCH}_{3}\right), 1.96-2.18(\mathrm{~m}, 2 \mathrm{H}$, $\left.\mathrm{CH}_{2}\right), 0.96\left(\mathrm{t}, J=7.22 \mathrm{~Hz}, 3 \mathrm{H}, \mathrm{CH}_{3}\right)$. HRMS $\left(\mathrm{ESI},[\mathrm{M}+\mathrm{H}]^{+}\right)$: calcd for $\mathrm{C}_{26} \mathrm{H}_{23} \mathrm{ClN}_{5} \mathrm{O}_{2}, 472.1541$; found, 472.1543. $[\alpha]_{\mathrm{D}}^{20}+29.5 \pm 0.7(c=$ 1 , DMSO).

(2R)-2-\{[2-(3'-Chloro-2'-fluorobiphenyl-4-yl)-3-cyano-1,7-naphthyridin-4-yl]amino\}butanamide (BAY-297, 58). A reaction mixture of $12(100 \mathrm{mg}, 0.244 \mathrm{mmol}),(3$-chloro-2-fluorophenyl)boronic acid $(85 \mathrm{mg}, 0.487 \mathrm{mmol}$, commercially available, CAS-RN: [352535-821]), $\left[1,1^{\prime}\right.$-Bis (diphenylphosphino)ferrocene $]$ palladium(II) dichloride $(40 \mathrm{mg}, 0.049 \mathrm{mmol})$, and $2 \mathrm{M}$ aq. potassium carbonate solution (0.61 $\mathrm{mL}, 1.219 \mathrm{mmol})$ in 1,4-dioxane $(2 \mathrm{~mL})$ was heated at $100^{\circ} \mathrm{C}$ for 12 $h$. The solvent was removed under reduced pressure and the crude material was purified by preparative HPLC (basic conditions) to give compound $58(59 \mathrm{mg}, 52 \%)$. LC-MS (basic conditions): ${ }^{t} \mathrm{R}=1.22$ min. MS $\left(\mathrm{ESI}^{+}\right): m / z=460.3[\mathrm{M}+\mathrm{H}]^{+}$. ${ }^{1} \mathrm{H}$ NMR $(400 \mathrm{MHz}$, DMSO- $\left.d_{6}\right): \delta=9.26(\mathrm{~s}, 1 \mathrm{H}$, pyridine $), 8.68(\mathrm{br} \mathrm{d}, J=5.32 \mathrm{~Hz}, 1 \mathrm{H}$, pyridine), 8.38 (d, $J=5.83 \mathrm{~Hz}, 1 \mathrm{H}$, pyridine), 7.84-7.96 $(\mathrm{m}, 3 \mathrm{H}$, phenyl, NH), 7.72-7.81 (m, 3H, phenyl, NH), 7.59-7.69 (m, 2H, phenyl), 7.35-7.44 (m, 2H, phenyl, NH), 4.96-5.03 (m, $1 \mathrm{H}, \mathrm{CH}-$ $\mathrm{C}(\mathrm{O})), 1.96-2.17\left(\mathrm{~m}, 2 \mathrm{H}, \mathrm{CH}_{2}\right), 0.96\left(\mathrm{t}, J=7.35 \mathrm{~Hz}, 3 \mathrm{H}, \mathrm{CH}_{3}\right) .{ }^{19} \mathrm{~F}$ NMR $\left(377 \mathrm{MHz}\right.$, DMSO- $\left.d_{6}\right): \delta=-121.03(\mathrm{~s}, 1 \mathrm{~F})$. HRMS (ESI, [M $+\mathrm{H}]^{+}$): calcd for $\mathrm{C}_{25} \mathrm{H}_{20} \mathrm{ClFN}_{5} \mathrm{O}, 460.1341$; found, 460.1343. $[\alpha]_{\mathrm{D}}^{20}$ $+37.9 \pm 1.63(c=1$, DMSO $)$.

(2R)-2-\{[3-Cyano-2-(2'-fluoro-3'-methylbiphenyl-4-yl)-1,7-naphthyridin-4-yl]amino\}butanamide (59). Compound 59 (35 mg, 26\%) was prepared analogously to 17 , from 12 and (2-fluoro-3methylphenyl)boronic acid (CAS-RN: [762287-58-1]). LC-MS (acidic conditions): ${ }^{t} \mathrm{R}=1.21 \mathrm{~min}$. MS $\left(\mathrm{ESI}^{+}\right): \mathrm{m} / z=440.3[\mathrm{M}+$ $\mathrm{H}]^{+} .{ }^{1} \mathrm{H}$ NMR (400 MHz, DMSO- $\left.d_{6}\right): \delta=9.25$ (s, $1 \mathrm{H}$, pyridine), 
$8.67(\mathrm{~d}, J=5.83 \mathrm{~Hz}, 1 \mathrm{H}$, pyridine), $8.38($ br d, $J=5.83 \mathrm{~Hz}, 1 \mathrm{H}$, pyridine), 7.77-7.94 (m, $4 \mathrm{H}$, phenyl, NH), $7.70($ br d, $J=7.35 \mathrm{~Hz}$, $2 \mathrm{H}$, phenyl), 7.32-7.57 (m, 3H, phenyl, $\mathrm{NH}), 7.19-7.29(\mathrm{~m}, 1 \mathrm{H}$, phenyl), 4.95-5.04 (m, $1 \mathrm{H}, \mathrm{CH}-\mathrm{C}(\mathrm{O})), 2.33\left(\mathrm{~s}, 3 \mathrm{H}, \mathrm{CH}_{3}\right), 1.96-$ $2.21\left(\mathrm{~m}, 2 \mathrm{H}, \mathrm{CH}_{2}\right), 0.96\left(\right.$ br t $\left.J=7.35 \mathrm{~Hz}, 3 \mathrm{H}, \mathrm{CH}_{3}\right)$. HRMS (ESI, $\left.[\mathrm{M}+\mathrm{H}]^{+}\right)$: calcd for $\mathrm{C}_{26} \mathrm{H}_{23} \mathrm{FN}_{5} \mathrm{O}, 440.1888$; found, 440.1885 .

(2R)-2-\{[3-Cyano-2-(2'-fluoro-3'-methylbiphenyl-4-yl)-1,7-naphthyridin-4-yl]amino\}butanoic Acid (BAY-091, 60). A reaction mixture of 10 (200 mg, $0.486 \mathrm{mmol}$ ), (2-fluoro-3-methylphenyl)boronic acid $(94 \mathrm{mg}, 0.608 \mathrm{mmol}$, commercially available, CAS-RN: [762287-58-1]), [1,1'-bis(diphenylphosphino)-ferrocene]palladium(II) dichloride (79 mg, $0.097 \mathrm{mmol}$ ), and $2 \mathrm{M}$ aq. potassium carbonate solution $(1.22 \mathrm{~mL}, 2.43 \mathrm{mmol})$ in 1,4-dioxane $(7 \mathrm{~mL})$ was heated at $60^{\circ} \mathrm{C}$ for $17 \mathrm{~h}$. Water and ethyl acetate were added to the reaction mixture and the phases separated. The aqueous phase was washed with ethyl acetate (2-times). The organic phases were combined, and the solvent was removed under reduced pressure. The crude material was purified by preparative HPLC (basic conditions) to give compound $60(40 \mathrm{mg}, 19 \%)$. LC-MS (acidic conditions): ${ }^{t} \mathrm{R}=$ $1.25 \mathrm{~min}$. MS $\left(\mathrm{ESI}^{+}\right): m / z=441.3[\mathrm{M}+\mathrm{H}]^{+} .{ }^{1} \mathrm{H}$ NMR $(400 \mathrm{MHz}$, DMSO- $\left.d_{6}\right): \delta=9.24(\mathrm{~s}, 1 \mathrm{H}$, pyridine $), 8.67(\mathrm{~d}, J=5.58 \mathrm{~Hz}, 1 \mathrm{H}$, pyridine $), 8.20-8.38(\mathrm{~m}, 2 \mathrm{H}$, pyridine, $\mathrm{NH}), 7.90(\mathrm{~d}, J=7.70 \mathrm{~Hz}$, $2 \mathrm{H}$, phenyl), 7.69 (dd, $J=1.39,8.24 \mathrm{~Hz}, 2 \mathrm{H}$, phenyl), $7.29-7.48(\mathrm{~m}$, $2 \mathrm{H}$, phenyl), 7.18-7.27 (m, 1H, phenyl), $4.91(\mathrm{br} \mathrm{d}, J=5.32 \mathrm{~Hz}, 1 \mathrm{H}$, $\mathrm{CH}-\mathrm{C}(\mathrm{O})), 2.33\left(\mathrm{~d}, J=1.77 \mathrm{~Hz}, 3 \mathrm{H}, \mathrm{CH}_{3}\right), 2.00-2.13(\mathrm{~m}, 2 \mathrm{H}$, $\left.\mathrm{CH}_{2}\right), 0.97\left(\mathrm{t}, J=7.35 \mathrm{~Hz}, 3 \mathrm{H}, \mathrm{CH}_{3}\right) .{ }^{13} \mathrm{C}$ NMR $(101 \mathrm{MHz}, \mathrm{DMSO}-$ $\left.d_{6}\right): \delta=172.0,162.0,158.8,156.4,153.3,152.1,144.0,141.8,138.0$, $136.6,131.3,129.3,128.3,127.4,125.2,125.1,124.5,121.5,118.8$, 114.0, 84.0, 57.7, 40.5, 25.1, 14.5, 9.3. ${ }^{19} \mathrm{~F}$ NMR (377 MHz, DMSO$\left.d_{6}\right): \delta=-123.02($ br s, $1 \mathrm{~F})$. HRMS (ESI, $\left.[\mathrm{M}+\mathrm{H}]^{+}\right)$: calcd for $\mathrm{C}_{26} \mathrm{H}_{22} \mathrm{FN}_{4} \mathrm{O}_{2}$, 441.1728; found, 441.1723. $[\alpha]_{\mathrm{D}}^{20}+135.13^{\circ}(c=1$, DMSO).

(2R)-2-\{[2-(3'-Chloro-2'-fluorobiphenyl-4-yl)-3-cyano-1,7-naphthyridin-4-yl]amino\}butanoic Acid (61). Step 1: Compound 9 (6.5 g, $77 \%)$ was prepared analogously to 13 , from $\mathbf{8 b}$ and tert-butyl $(R)-2$ aminobutanoate hydrochloride ( $\mathrm{H}-\mathrm{D}-\mathrm{Abu}-\mathrm{Ot}-\mathrm{Bu} \cdot \mathrm{HCl})$ (commercially available, CAS-RN: [313994-32-0]). ${ }^{1} \mathrm{H}$ NMR (400 MHz, DMSO$\left.d_{6}\right): \delta=9.25(\mathrm{~s}, 1 \mathrm{H}$, pyridine $), 8.69(\mathrm{~d}, J=5.83 \mathrm{~Hz}, 1 \mathrm{H}$, pyridine $)$, $8.49(\mathrm{~d}, J=5.58 \mathrm{~Hz}, 1 \mathrm{H}$, pyridine $), 8.02(\mathrm{br} \mathrm{d}, 1 \mathrm{H}, J=8.87 \mathrm{~Hz}, \mathrm{NH})$, $7.75(\mathrm{~s}, 4 \mathrm{H}$, phenyl), $4.98(\mathrm{dt}, J=5.20,8.55 \mathrm{~Hz}, 1 \mathrm{H}, \mathrm{CH}-\mathrm{C}(\mathrm{O}))$, $1.98-2.14\left(\mathrm{~m}, 2 \mathrm{H}, \mathrm{CH}_{2}\right), 1.41(\mathrm{~s}, 9 \mathrm{H}, t-\mathrm{Bu}), 1.03(\mathrm{t}, J=7.35 \mathrm{~Hz}, 3 \mathrm{H}$, $\left.\mathrm{CH}_{3}\right)$. MS $\left(\mathrm{ESI}^{+}\right): m / z=469.1[\mathrm{M}+\mathrm{H}]^{+}$. Step 2: tert-Butyl (2R)-2$\{[2$-(3'-chloro-2' -fluorobiphenyl-4-yl)-3-cyano-1,7-naphthyridin-4yl]amino $\}$-butanoate $(238 \mathrm{mg}, 72 \%)$ was prepared analogously to 17 , from 9 and (3-chloro-2-fluorophenyl)boronic acid (commercially available, CAS-RN: [352535-82-1]). ${ }^{1} \mathrm{H}$ NMR $(400 \mathrm{MHz}$, DMSO$\left.d_{6}\right): \delta=9.27(\mathrm{~s}, 1 \mathrm{H}$, pyridine $), 8.69(\mathrm{~d}, J=5.83 \mathrm{~Hz}, 1 \mathrm{H}$, pyridine $)$, $8.51(\mathrm{~d}, J=5.58 \mathrm{~Hz}, 1 \mathrm{H}$, pyridine $), 8.01(\mathrm{~d}, J=8.62 \mathrm{~Hz}, 1 \mathrm{H}, \mathrm{NH})$, $7.93(\mathrm{~d}, J=7.96 \mathrm{~Hz}, 2 \mathrm{H}$, phenyl), 7.59-7.76 (m, 4H, phenyl), 7.38 $(\mathrm{dt}, J=0.89,7.92 \mathrm{~Hz}, 1 \mathrm{H}$, phenyl), $5.02(\mathrm{dt}, J=5.20,8.55 \mathrm{~Hz}, 1 \mathrm{H}$, CH-C(O)), 1.98-2.15 (m, 2H, $\left.\mathrm{CH}_{2}\right), 1.42(\mathrm{~s}, 9 \mathrm{H}, t-\mathrm{Bu}), 1.05(\mathrm{t}, J=$ $\left.7.35 \mathrm{~Hz}, 3 \mathrm{H}, \mathrm{CH}_{3}\right) . \mathrm{MS}\left(\mathrm{ESI}^{+}\right): m / z=517.1[\mathrm{M}+\mathrm{H}]^{+}$. Step 3: Compound $61(100 \mathrm{mg}, 61 \%)$ was prepared analogously to 10 , from tert-butyl (2R)-2-\{[2-(3'-chloro-2'-fluorobiphenyl-4-yl)-3-cyano-1,7naphthyridin-4-yl] amino $\}$-butanoate. LC-MS (basic conditions): ${ }^{t} \mathrm{R}$ $=0.84 \mathrm{~min} . \mathrm{MS}\left(\mathrm{ESI}^{+}\right): m / z=461.4[\mathrm{M}+\mathrm{H}]^{+} .{ }^{1} \mathrm{H} \mathrm{NMR}(400 \mathrm{MHz}$, DMSO- $\left.d_{6}\right): \delta=13.16\left(\mathrm{~s}, 1 \mathrm{H}, \mathrm{CO}_{2} \mathrm{H}\right), 9.27(\mathrm{~s}, 1 \mathrm{H}$, pyridine $), 8.69(\mathrm{~d}$, $J=5.83 \mathrm{~Hz}, 1 \mathrm{H}$, pyridine $), 8.51(\mathrm{~d}, J=5.58 \mathrm{~Hz}, 1 \mathrm{H}$, pyridine $), 8.04$ $(\mathrm{d}, J=8.87 \mathrm{~Hz}, 1 \mathrm{H}, \mathrm{NH}), 7.90-7.97(\mathrm{~m}, 2 \mathrm{H}$, phenyl), 7.59-7.76 (m, $4 \mathrm{H}$, phenyl), $7.38(\mathrm{dt}, J=1.01,7.86 \mathrm{~Hz}, 1 \mathrm{H}$, phenyl), $5.10(\mathrm{dt}, J=$ 4.69, $8.81 \mathrm{~Hz}, 1 \mathrm{H}, \mathrm{CH}-\mathrm{C}(\mathrm{O})), 2.03-2.19\left(\mathrm{~m}, 2 \mathrm{H}, \mathrm{CH}_{2}\right), 1.05(\mathrm{t}, J=$ $\left.7.35 \mathrm{~Hz}, 3 \mathrm{H}, \mathrm{CH}_{3}\right)$.

(2R)-2-\{[5-Chloro-3-cyano-2-(2'-ethoxybiphenyl-4-yl)-1,7-naphthyridin-4-yl]amino\}butanamide (62). Step 1: 1-[(3-Amino-5fluoroisonicotinoyl)oxy]pyrrolidine-2,5-dione (20.1 g, 30\%) was prepared analogously to 5 , from 3-amino-5-fluoropyridine-4-carboxylic acid (commercially available, CAS-RN: [1805693-18-8]) and 4. ${ }^{1} \mathrm{H}$ NMR (400 MHz, DMSO- $\left.d_{6}\right): \delta=8.20(\mathrm{~s}, 1 \mathrm{H}$, pyridine), $7.78(\mathrm{~d}$, $J=2.53 \mathrm{~Hz}, 1 \mathrm{H}$, pyridine), 7.19 (br s, $\left.2 \mathrm{H}, \mathrm{NH}_{2}\right), 2.88\left(\mathrm{~s}, 4 \mathrm{H}, \mathrm{CH}_{2}\right)$. Step 2: 2-(4-Bromophenyl)-5-hydroxy-4-oxo-1,4-dihydro-1,7-naph- thyridine-3-carbonitrile (5.35 g, 19\%) was prepared analogously to 7, from 1-[(3-amino-5-fluoroisonicotinoyl)oxy]pyrrolidine-2,5-dione $(20.7 \mathrm{~g}, 81.76 \mathrm{mmol})$ and $6 .{ }^{1} \mathrm{H}$ NMR $\left(400 \mathrm{MHz}, \mathrm{DMSO}-d_{6}\right): \delta=$ 13.15-14.06 (br s, $1 \mathrm{H}, \mathrm{OH}), 12.45-12.98$ (br s, $1 \mathrm{H}, \mathrm{NH}), 8.58$ (s, $1 \mathrm{H}$, pyridine), $8.14(\mathrm{~s}, 1 \mathrm{H}$, pyridine), $7.89(\mathrm{~d}, J=8.36 \mathrm{~Hz}, 2 \mathrm{H}$, phenyl), 7.78 (d, $J=8.36 \mathrm{~Hz}, 2 \mathrm{H}$, phenyl). MS $\left(\mathrm{ESI}^{+}\right): m / z=342.0$ $[\mathrm{M}+\mathrm{H}]^{+}$. Step 3: 2-(4-Bromophenyl)-4,5-dichloro-1,7-naphthyridine-3-carbonitrile $(2.64 \mathrm{~g}, 59 \%)$ was prepared analogously to $8 \mathbf{a}$, from 2-(4-bromophenyl)-5-hydroxy-4-oxo-1,4-dihydro-1,7-naphthyridine-3-carbonitrile and $\mathrm{POCl}_{3} \cdot{ }^{1} \mathrm{H}$ NMR $\left(400 \mathrm{MHz}, \mathrm{DMSO}-d_{6}\right): \delta=$ $9.53(\mathrm{~s}, 1 \mathrm{H}$, pyridine $), 8.94(\mathrm{~s}, 1 \mathrm{H}$, pyridine $), 7.86-7.94(\mathrm{~m}, 4 \mathrm{H}$, phenyl). MS $\left(\mathrm{ESI}^{+}\right): m / z=379.9[\mathrm{M}+\mathrm{H}]^{+}$. Step 4: $(2 \mathrm{R})-2-\{[2-(4-$ Bromophenyl)-5-chloro-3-cyano-1,7-naphthyridin-4-yl]amino $\}$ butanamide $(1 \mathrm{~g}, 88 \%)$ was prepared analogously to 13 , from 2-(4bromophenyl)-4,5-dichloro-1,7-naphthyridine-3-carbonitrile and (2R)-2-aminobutanamide hydrochloride (commercially available, CAS-RN: [103765-03-3]). ${ }^{1} \mathrm{H}$ NMR (500 MHz, DMSO- $\left.d_{6}\right): \delta=$ $9.14(\mathrm{~s}, 1 \mathrm{H}$, pyridine), $9.12(\mathrm{~d}, J=6.99 \mathrm{~Hz}, 1 \mathrm{H}, \mathrm{NH}), 8.64(\mathrm{~s}, 1 \mathrm{H}$, pyridine $), 8.06(\mathrm{~s}, 1 \mathrm{H}, \mathrm{NH}), 7.72-7.79(\mathrm{~m}, 4 \mathrm{H}$, phenyl $), 7.63(\mathrm{~s}, 1 \mathrm{H}$, $\mathrm{NH}), 5.19-5.24(\mathrm{~m}, 1 \mathrm{H}, \mathrm{CHC}(\mathrm{O})), 2.07-2.17\left(\mathrm{~m}, 1 \mathrm{H}, \mathrm{CH}_{2}\right), 1.99-$ $2.07\left(\mathrm{~m}, 1 \mathrm{H}, \mathrm{CH}_{2}\right), 0.85\left(\mathrm{t}, J=7.32 \mathrm{~Hz}, 3 \mathrm{H}, \mathrm{CH}_{3}\right) . \mathrm{MS}\left(\mathrm{ESI}^{+}\right): \mathrm{m} / z$ $=446.0[\mathrm{M}+\mathrm{H}]^{+}$. Step 5: Compound $62(42 \mathrm{mg}, 38 \%)$ was prepared analogously to 17 , from (2R)-2-\{[2-(4-bromophenyl)-5-chloro-3cyano-1,7-naphthyridin-4-yl] amino $\}$ butanamide and (2ethoxyphenyl)boronic acid (commercially available, CAS-RN: [213211-69-9]). LC-MS (basic conditions): ${ }^{t} \mathrm{R}=1.35 \mathrm{~min}$. MS $\left(\mathrm{ESI}^{+}\right): m / z=486.5[\mathrm{M}+\mathrm{H}]^{+} .{ }^{1} \mathrm{H}$ NMR $\left(400 \mathrm{MHz}, \mathrm{CDCl}_{3}\right): \delta=$ $9.25(\mathrm{~s}, 1 \mathrm{H}$, pyridine), 8.99 (d, $J=7.35 \mathrm{~Hz}, 1 \mathrm{H}, \mathrm{NH}), 8.54(\mathrm{~s}, 1 \mathrm{H}$, pyridine), $7.81-7.91(\mathrm{~m}, 2 \mathrm{H}$, phenyl), 7.68-7.76 (m, $2 \mathrm{H}$, phenyl), 7.30-7.44 (m, 2H, phenyl), 6.96-7.11 (m, 2H, phenyl), 5.80-5.96 (br s, $1 \mathrm{H}, \mathrm{NH}), 5.56-5.70($ br s, $1 \mathrm{H}, \mathrm{NH}), 5.35-5.50(\mathrm{~m}, 1 \mathrm{H}$, $\mathrm{CHC}(\mathrm{O})), 4.09\left(\mathrm{~m}, 2 \mathrm{H}, \mathrm{OCH}_{2}\right), 2.16-2.33\left(\mathrm{~m}, 1 \mathrm{H}, \mathrm{CH}_{2}\right), 1.94-$ $2.12\left(\mathrm{~m}, 1 \mathrm{H}, \mathrm{CH}_{2}\right), 1.38\left(\mathrm{t}, J=6.97 \mathrm{~Hz}, 3 \mathrm{H}, \mathrm{CH}_{3}\right), 1.06(\mathrm{t}, J=7.48$ $\mathrm{Hz}, 3 \mathrm{H}, \mathrm{CH}_{3}$ ). HRMS (ESI, $[\mathrm{M}+\mathrm{H}]^{+}$): calcd for $\mathrm{C}_{27} \mathrm{H}_{25} \mathrm{ClN}_{5} \mathrm{O}_{2}$, 486.1698; found, 486.1695. $[\alpha]_{\mathrm{D}}^{20}-113.4 \pm 2.66(c=1$, DMSO $)$.

$N$-[2-(2'-Ethoxybiphenyl-4-yl)pyrido[3,4-d]pyrimidin-4-yl]alanine (63). Step 1: To a solution of methyl 3-aminopyridine-4carboxylate $(1.576 \mathrm{~g}, 10.35 \mathrm{mmol})$ in DCM $(15 \mathrm{~mL})$ were added, at $\mathrm{rt}, \mathrm{Et}_{3} \mathrm{~N}(2.17 \mathrm{~mL}, 15.5 \mathrm{mmol})$ and 4-bromobenzoyl chloride $(2.5 \mathrm{~g}$, $11.39 \mathrm{mmol}$ ), and the reaction mixture was stirred at rt overnight. Then, the mixture was diluted with DCM and washed with saturated sodium bicarbonate solution $(2 \times)$ and brine $(2 \times)$. The organic layer was dried over $\mathrm{Na}_{2} \mathrm{SO}_{4}$, and the solvent was removed under reduced pressure. The crude product was purified by flash chromatography (amine column, eluent: hexanes/DCM 10-80\%) to yield methyl 3[(4-bromobenzoyl)amino] isonicotinate $(2.86 \mathrm{~g}, 82 \%) .{ }^{1} \mathrm{H}$ NMR (400 $\left.\mathrm{MHz}, \mathrm{DMSO}-d_{6}\right): \delta=10.97(\mathrm{~s}, 1 \mathrm{H}, \mathrm{NH}), 9.25(\mathrm{~s}, 1 \mathrm{H}$, pyridine), 8.54 (d, $J=5.07 \mathrm{~Hz}, 1 \mathrm{H}$, pyridine), $7.88-7.94(\mathrm{~m}, 2 \mathrm{H}$, phenyl), $7.80-7.85$ (m, $2 \mathrm{H}$, phenyl), 7.74-7.78 (m, $1 \mathrm{H}$, pyridine), $3.84\left(\mathrm{~s}, 3 \mathrm{H}, \mathrm{CH}_{3}\right)$. Step 2: To a solution of methyl 3-[(4-bromobenzoyl)amino]isonicotinate $(2.86 \mathrm{~g}, 8.53 \mathrm{mmol})$ in $\mathrm{MeOH}(100 \mathrm{~mL})$ were added saturated ammonium hydroxide solution $(100 \mathrm{~mL})$ and THF $(100$ $\mathrm{mL}$ ). The reaction mixture was stirred at rt overnight, $2 \mathrm{M}$ aq $\mathrm{NaOH}$ solution $(43 \mathrm{~mL})$ was added, and the mixture was stirred under reflux for $2 \mathrm{~h}$. The solvent was removed under reduced pressure, and the residue was suspended in $\mathrm{H}_{2} \mathrm{O}$, acidified with $1 \mathrm{~N}$ aqueous $\mathrm{HCl}$, and extracted with DCM $(3 \times)$. The insoluble residue was isolated by filtration and dried under reduced pressure to yield crude 2-(4bromophenyl)pyrido[3,4-d] pyrimidin-4-ol hydrochloride (1.46 g, $43 \%$ yield, $85 \%$ purity). MS $\left(\mathrm{ESI}^{+}\right): m / z=302[\mathrm{M}+\mathrm{H}]^{+}$. Step 3: A solution of 2-(4-bromophenyl)pyrido[3,4-d]pyrimidin-4-ol hydrochloride (251 mg, $0.741 \mathrm{mmol}), 2,4,6$-triisopropylbenzenesulfonyl chloride (449 mg, $1.483 \mathrm{mmol}$ ), and 4-(dimethylamino)pyridine (18 $\mathrm{mg}, 148 \mu \mathrm{mol})$ in DMF $(4.5 \mathrm{~mL})$ was stirred at $\mathrm{rt}$ for $1 \mathrm{~h}$. (2R)-2Aminobutanamide hydrochloride (1:1) (134 mg, $0.964 \mathrm{mmol})$ was added to the solution and the reaction mixture was stirred at $\mathrm{rt}$ overnight. The solvent was removed under reduced pressure, and the residue was purified by preparative HPLC (basic conditions) to yield (2R)-2-\{[2-(4-bromophenyl)pyrido[3,4-d]pyrimidin-4-yl] amino $\}$ butanamide (117 mg, 39\%). ${ }^{1} \mathrm{H}$ NMR (DMSO-d $\left.{ }_{6}\right) \delta: 9.16$ (d, J = 0.8 
$\mathrm{Hz}, 1 \mathrm{H}$, pyridine), $8.62(\mathrm{~d}, \mathrm{~J}=5.6 \mathrm{~Hz}, 1 \mathrm{H}$, pyridine $), 8.58(\mathrm{~d}, \mathrm{~J}=7.1$ $\mathrm{Hz}, 1 \mathrm{H}, \mathrm{NH}), 8.42-8.49(\mathrm{~m}, 2 \mathrm{H}$, phenyl), 8.34-8.40 (m, $1 \mathrm{H}$, pyridine), 7.65-7.74 (m, 3H, phenyl, $\mathrm{NH}), 7.10(\mathrm{~s}, 1 \mathrm{H}, \mathrm{NH}), 4.59-$ $4.77(\mathrm{~m}, 1 \mathrm{H}, \mathrm{CHC}(\mathrm{O})), 1.81-2.09\left(\mathrm{~m}, 2 \mathrm{H}, \mathrm{CH}_{2}\right), 1.03(\mathrm{t}, \mathrm{J}=7.4$ $\left.\mathrm{Hz}, 3 \mathrm{H}, \mathrm{CH}_{3}\right)$. MS $\left(\mathrm{ESI}^{+}\right): m / z=387.1[\mathrm{M}+\mathrm{H}]^{+}$. Step 4: Compound $63(76 \mathrm{mg}, 76 \%)$ was prepared analogously to 17 , from (2R)-2-\{[2-(4-bromophenyl)pyrido[3,4-d]pyrimidin-4-yl]amino $\}$-butanamide $(100 \mathrm{mg}, 0.26 \mathrm{mmol})$ and (2-ethoxyphenyl)boronic acid (73 mg, $0.44 \mathrm{mmol}$, commercially available, CAS-RN: [213211-699]). LC-MS (acidic conditions): ${ }^{t} \mathrm{R}=1.11 \mathrm{~min} . \mathrm{MS}\left(\mathrm{ESI}^{+}\right): \mathrm{m} / z=$ $428.2[\mathrm{M}+\mathrm{H}]^{+} .{ }^{1} \mathrm{H}$ NMR (DMSO-d $\left.\mathrm{d}_{6}\right) \delta: 9.16$ (s, $1 \mathrm{H}$, pyridine), 8.61 (d, $\mathrm{J}=5.6 \mathrm{~Hz}, 1 \mathrm{H}$, pyridine), $8.49-8.57(\mathrm{~m}, 3 \mathrm{H}$, phenyl, $\mathrm{NH}), 8.38$ (d, J = 5.6 Hz, $1 \mathrm{H}$, pyridine), 7.68-7.73 (m, 1H, NH), $7.65(\mathrm{~d}, \mathrm{~J}=$ $8.4 \mathrm{~Hz}, 2 \mathrm{H}$, phenyl), 7.31-7.42 (m, $2 \mathrm{H}$, phenyl), 7.11-7.16 (m, $2 \mathrm{H}$, phenyl, $\mathrm{NH}$ ), $7.01-7.09$ (m, $1 \mathrm{H}$, phenyl), 4.75 (br dd, $\mathrm{J}=5.4,1.9 \mathrm{~Hz}$, $1 \mathrm{H}, \mathrm{CHC}(\mathrm{O})), 4.08\left(\mathrm{q}, \mathrm{J}=6.8 \mathrm{~Hz}, 2 \mathrm{H}, \mathrm{O} \mathrm{CH}_{2}\right), 1.85-2.08(\mathrm{~m}, 2 \mathrm{H}$, $\left.\mathrm{CH}_{2}\right), 1.30\left(\mathrm{t}, \mathrm{J}=6.8 \mathrm{~Hz}, 3 \mathrm{H}, \mathrm{CH}_{3}\right), 1.05\left(\mathrm{t}, \mathrm{J}=7.4 \mathrm{~Hz}, 3 \mathrm{H}, \mathrm{CH}_{3}\right)$.

Biochemical Assays. Biochemical PIP4K2A Inhibition Assay Monitoring ATP Consumption. The recombinant PIP4K2A protein was N-terminally $6 \times$ His-tagged and full length, expressed in Sf21 insect cells, purified using $\mathrm{Ni}^{2+} / \mathrm{NTA}$ agarose (purchased from Millipore). The substrate for the kinase reaction was phosphatidylinositol-5-phosphate $\mathrm{diC} 8[\mathrm{PI}(5) \mathrm{P} \mathrm{diC} 8]$, which is commercially available (Echelon Biosciences \#P-5008). For the assay, $50 \mathrm{~nL}$ of a 100 -fold concentrated solution of the test compound in DMSO was pipetted into either a white low-volume 384-well microtiter plate or a white 1536-well microtiter plate (both Greiner Bio-One); $2-2.5 \mu \mathrm{L}$ of a solution of PIP4K2A in aqueous assay buffer [25 mM HEPES $\mathrm{pH}$ 7.8, 0.3 mM EGTA, 0.1\% CHAPS, $5 \mathrm{mM} \mathrm{MgCl}_{2}, 12.5 \mathrm{mM} \mathrm{NaCl}, 1$ $\mathrm{mM}$ dithiothreitol] was added and the mixture was incubated at 22 ${ }^{\circ} \mathrm{C}$ for $20 \mathrm{~min}$ to allow prebinding of the test compound to the enzyme before the start of the kinase reaction. Then, the kinase reaction was started by the addition of $2-2.5 \mu \mathrm{L}$ of a solution of ATP $(20 \mu \mathrm{M}$ ATP $\rightarrow$ final assay concentration: $10 \mu \mathrm{M})$ and substrate $(30$ $\mu \mathrm{M} \rightarrow$ final assay concentration: $15 \mu \mathrm{M})$ in assay buffer and the resulting mixture was incubated at $22{ }^{\circ} \mathrm{C}$ for $60 \mathrm{~min}$. The assay concentration of PIP4K2A was adjusted depending on the activity of the enzyme lot and was chosen appropriately to run the assay in the linear range; a typical concentration was $2 \mathrm{nM}$. The reaction was stopped by the addition of $2 \mu \mathrm{L}$ of ADP-Glo reagent and, after $45 \mathrm{~min}$ at $22{ }^{\circ} \mathrm{C}, 2 \mu \mathrm{L}$ of kinase detection buffer was added (both parts of the ADP-Glo Kinase Assay Kit, Promega, Madison, WI). Subsequently, the amount of ATP consumed during the kinase reaction was evaluated by the measurement of luminescence with an appropriate reader [e.g., PHERAstar FS (BMG Labtech) or ViewLux (PerkinElmer)]. The data were normalized (enzyme reaction without inhibitor $=0 \%$ inhibition, all other assay components but no enzyme $=100 \%$ inhibition). Usually, the test compounds were tested on the same microtiter plate at 11 different concentrations in the range of 20 $\mu \mathrm{M}$ to $0.07 \mathrm{nM}(20 \mu \mathrm{M}, 5.7 \mu \mathrm{M}, 1.6 \mu \mathrm{M}, 0.47 \mu \mathrm{M}, 0.13 \mu \mathrm{M}, 38 \mathrm{nM}$, $11 \mathrm{nM}, 3.1 \mathrm{nM}, 0.9 \mathrm{nM}, 0.25 \mathrm{nM}$, and $0.07 \mathrm{nM}$; the dilution series was prepared separately, before the assay, on the 100 -fold concentrated solutions in DMSO by serial dilutions. Exact concentrations may vary depending on the pipettor used) in duplicate values for each concentration. $\mathrm{IC}_{50}$ values were calculated using Genedata Screener software.

Biochemical PIP4K2A Inhibition Assay Monitoring ATP Consumption-High ATP Version. To assess the mode of action of inhibitors, a version of the assay above was developed using a 25 -fold increased ATP concentration $(250 \mu \mathrm{M})$. The assay concentration of PIP4K2A was adjusted depending on the activity of the enzyme lot and was chosen appropriately to run the assay in the linear range.

Biochemical PIP4K2A Inhibition Assay (HTRF Binding Competition Assay). For the recombinant PIP4K2A protein source and compound preparation, see above. A commercially available HTRF assay (Millipore \#33-055) was used to quantify the PI4,5 $\mathrm{P}_{2}$ reaction product: $\mathrm{PI} 4,5 \mathrm{P}_{2}$ was detected by the displacement of a biotinylated ligand from an energy-transfer complex consisting of a europiumlabeled anti-GST monoclonal antibody and a GST-tagged Pleckstrin homology domain. For the assay, $2-2.5 \mu \mathrm{L}$ of a solution of PIP4K2A in aqueous $1 \times$ reaction buffer was added and the mixture was incubated at $22{ }^{\circ} \mathrm{C}$ for $20 \mathrm{~min}$ to allow prebinding of the test compound to the enzyme before the start of the kinase reaction. Then, the kinase reaction was started by the addition of $2-2.5 \mu \mathrm{L}$ of a solution of ATP and a substrate in assay buffer (final assay concentration: ATP, $10 \mu \mathrm{M}$; substrate, $75 \mu \mathrm{M}$ ) and the resulting mixture was incubated at $22{ }^{\circ} \mathrm{C}$ for $20 \mathrm{~min}$. Subsequently, $1.5 \mu \mathrm{L}$ of stop solution and $1.5 \mu \mathrm{L}$ of detection solution were added. After incubation for $60 \mathrm{~min}$ at $22{ }^{\circ} \mathrm{C}$, the HTRF signal was read with an appropriate reader [e.g., PHERAstar FS (BMG Labtech) or ViewLux (PerkinElmer)]. The assay concentration of PIP4K2A was adjusted depending on the activity of the enzyme lot and was chosen appropriately to run the assay in the linear range; a typical concentration was $7.5 \mathrm{nM}$. For data normalization, see above.

Biochemical PIP4K2A Inhibition Assay (HTRF Binding Competition Assay) - High ATP Version. To assess the mode of action of inhibitors, a version of the assay above was developed using a 200 -fold increased ATP concentration $(2 \mathrm{mM})$. The assay concentration of PIP4K2A was adjusted depending on the activity of the enzyme lot and was chosen appropriately to run the assay in the linear range.

Cellular Assays. Cell Culture. Cell lines were obtained from the American Type Culture Collection and the Japanese Collection of Research Bioresources Cell Bank. They were maintained in the recommended cell culture media at $37{ }^{\circ} \mathrm{C}$ in $5 \% \mathrm{CO}_{2}$.

Phospho-AKT (Ser473) HTRF Assay. The phospho-AKT (Ser473) HTRF assay (Cisbio) was performed on THP-1 cells, according to the manufacturer's instructions. Briefly, on day 1, THP-1 cells were seeded at a density of 25000 cells/well in a 384-well Small Volume plate (Greiner Bio-One \#784075) in growth medium [RPMI 1640 (Biochrom \#FG1215) containing 10\% fetal calf serum (FCS, heatinactivated, Sigma \#F2442) and $0.05 \mathrm{mM} \beta$-mercaptoethanol (Gibco $\# 31350-010)]$. The cells were then treated with different compounds, added in serial dilutions using a HP D300 Digital Dispenser, and incubated at $37{ }^{\circ} \mathrm{C}$ for $2 \mathrm{~h}$. Following incubation, the plates were briefly centrifuged at $1000 \mathrm{rpm}$ and the cells were lysed in lysis buffer at $\mathrm{rt}$ for $1 \mathrm{~h}$, with shaking. Finally, the plates were centrifuged once again at $1000 \mathrm{rpm}$, the antibody solution was added, and the samples were incubated at rt overnight, in the dark, with shaking. The next day, the plates were read with a PHERAstar FS reader (BMG Labtech). $E_{50}$ values were calculated using the DRC Master Spreadsheet (Bella software), using DMSO-treated cells as the minimum control and cells treated with $1 \mu \mathrm{M}$ of AZD5363 as the maximum control.

ROS Assay. The levels of mitochondrial ROS were measured using a MitoSOX Red Mitochondrial Superoxide Indicator (Thermo Fisher \#M36008), according to the manufacturer's instructions. Briefly, THP-1 cells were treated with different compounds, added in serial dilutions using a HP D300 Digital Dispenser, and incubated at $37{ }^{\circ} \mathrm{C}$ for $1 \mathrm{~h}$. The cells were then collected by centrifugation in a 96-well Vbottom plate (Falcon \#353263), the medium was removed, and the cells were incubated with the MitoSOX Red dye at $37^{\circ} \mathrm{C}$ for $20 \mathrm{~min}$. The cells were then washed with PBS and incubated with DAPI solution for $2 \mathrm{~min}$. The cells were once again washed and collected with PBS, and fluorescence was measured using an FACS flow cytometer (FACSCanto II, BD Biosciences). $\mathrm{EC}_{50}$ values were calculated using the DRC Master Spreadsheet (Bella software), using DMSO-treated cells as the minimum control and cells treated with 5 $\mu \mathrm{M}$ of rotenone as the maximum control.

Proliferation Assays. For proliferation studies, THP-1, EBC-1 (p53 mut), or NCI-H460 (control, p53 WT) cells were plated in cell culture media at a density of 1000 cells $/ 30 \mu \mathrm{L} /$ well in 384-well black plates (Corning \#3571). Sister wells were plated in a separate plate for time zero determination, and all plates were incubated overnight at 37 ${ }^{\circ} \mathrm{C}$. The next day, the test compounds were added in serial dilutions using a HP D300 Digital Dispenser, and the cells were incubated at 37 ${ }^{\circ} \mathrm{C}$ for $72 \mathrm{~h}$. For measurement of the time zero plate, $30 \mu \mathrm{L} /$ well of CellTiter-Glo solution (Promega \#G7573) was added, followed by incubation for $2 \mathrm{~min}$ in an orbital shaker to induce cell lysis. After an additional incubation for $10 \mathrm{~min}$ at $\mathrm{rt}$, the luminescence was read with a PHERAstar FS reader (BMG Labtech). The plates incubated for 72 
$\mathrm{h}$ with test compounds were measured similarly. Control wells containing cells with culture medium and DMSO were used to determine the control cell growth at $72 \mathrm{~h}$ compared to the initial number of cells (time zero value). To distinguish between the cell growth inhibition and cell kill, the luminescence values after $72 \mathrm{~h}$ were corrected for the mean luminescence observed for the time zero wells at the day of test compound addition (time zero value). $\mathrm{IC}_{50}$ values, defined as the test compound concentration that corresponds to a reduction in cellular growth by $50 \%$ when compared with the value of DMSO control cells, were calculated using the DRC Master Spreadsheet (Bella software).

CETSA Measurements of Target Engagement on PIP4K2A in THP-1 Cell Lysates and Intact THP-1 Cells at Pelago Bioscience AB. General Methods and Materials. THP-1 cells were cultured at $37{ }^{\circ} \mathrm{C}$ with $5 \% \mathrm{CO}_{2}$ in RPMI 1640 medium (Gibco/Life Technologies) supplemented with $10 \%$ fetal bovine serum (Gibco/ Life Technologies), $100 \mathrm{U} / \mathrm{mL}$ penicillin, $100 \mathrm{U} / \mathrm{mL}$ streptomycin (Gibco/Life Technologies), and $0.05 \mathrm{mM} \beta$-mercaptoethanol. The cells were kept subconfluent and were fed with fresh medium 1 day prior to harvest. For experiments, the cells were pelleted by centrifugation, washed with Hanks' balanced salt solution (HBSS), pelleted again, and for lysate experiments dissolved at $40 \times 10^{6}$ cells/ $\mathrm{mL}$ in HEPES buffer [ $20 \mathrm{mM}$ HEPES, $138 \mathrm{mM} \mathrm{NaCl}, 1 \mathrm{mM} \mathrm{MgCl}{ }_{2}$, $5 \mathrm{mM} \mathrm{KCl}, 2 \mathrm{mM} \mathrm{CaCl}, \mathrm{pH} 7.4+$ cOmplete protease inhibitor cocktail (Roche)], and for intact cell experiments dissolved at the same concentration in the HBSS. The cells of passage 11 to 18 were used and with a cell viability above $90 \%$ after harvest.

The test compounds were aliquoted and stored at $-20{ }^{\circ} \mathrm{C}$. In the concentration-response experiments, dilution series in 100\% DMSO were prepared fresh before each experiment. The test compounds were further diluted to $2 \times$ the final test concentration in the HEPES buffer or in HBSS prior to addition to the lysate or cells.

This study was performed according to the general CETSA protocol $^{20}$ of first establishing melt curves and ligand-induced shifts followed by testing of the compounds in increasing concentration at a single temperature to establish the CETSA $\mathrm{EC}_{50}$ of target engagement on PIP4K2A. Experiments were run in sufficient replicates and repeated on different experimental days to yield statistically significant data, given assay noise and variability. This entailed at least two separate triplicate seven-step dilution concentration-response series $\left[N\right.$ days $\geq 2, n$ complete $\mathrm{C}-\mathrm{R}$ curves $\left.\left(\mathrm{EC}_{50}\right) \geq 6\right]$.

For optimal detection of PIP4K2A, protein samples were separated by electrophoresis on NuPAGE Novex 4-12\% Bis-Tris gels (Life Technologies) in MES buffer. Western blots were performed using an iBlot device (Bio-Rad) on nitrocellulose membranes. Protein transfer was optimized at $8 \mathrm{~min}$ at $25 \mathrm{~V}$. Blocking and dilution of antibodies was done in $5 \%$ nonfat milk in Tris-buffered saline/Tween. The commercially available primary antibody (Cell Signaling Technology \#5527) was used for the detection of PIP4K2A. The antibody was diluted at 1:1000 and incubated at $4{ }^{\circ} \mathrm{C}$ overnight. Chemiluminescent western blot detection was achieved using horseradish peroxidaseconjugated anti-rabbit secondary antibody W4011 (Promega) together with the Clarity Western ECL substrate (Bio-Rad).

Overall Study Design. All experiments were repeated on different days and with different passages of cells to reduce the risk of day-today variations ( $N$ individual incubations in data figures). Cell viability was measured by trypan 5 blue exclusion, before and after incubation, for both compound-treated and control incubations. Only cells with viabilities above $90 \%$ were included.

Generation of Melt and Shift Curves in THP-1 Cell Lysates. The THP-1 cell pellets resuspended in the HEPES buffer, at a cell density of $40 \times 10^{6}$ cells $/ \mathrm{mL}$, were lysed by three rounds of freeze-thawing before clarification by centrifugation at $20000 \mathrm{~g}$ for $20 \mathrm{~min}$, and the cell supernatant was collected. Equal volumes of the test compound (diluted to $2 \times$ the final test concentration in the HEPES buffer) and cells were mixed, resulting in a final cell density of $20 \times 10^{6}$ cells $/ \mathrm{mL}$ and $10 \mu \mathrm{M}$ of a test compound; $1 \%$ DMSO was used as a negative control. Incubation was performed at $37{ }^{\circ} \mathrm{C}$ for $30 \mathrm{~min}$ with continuous mixing. The treated cell lysates were divided into $60 \mu \mathrm{L}$ aliquots and subjected to a 12 -step heat challenge between 47 and 67
${ }^{\circ} \mathrm{C}$ for $3 \mathrm{~min}$. The precipitated protein was pelleted by centrifugation at $20000 \mathrm{~g}$ for $20 \mathrm{~min}$. Then, $40 \mu \mathrm{L}$ of the supernatants was mixed with $20 \mu \mathrm{L}$ of gel loading buffer (NuPAGE LDS sample buffer, Life Technologies), and $10 \mu \mathrm{L}$ of each mixture was loaded per lane on a gel. Protein amounts were detected using western blot techniques, as described above.

Generation of Melt and Shift Curves in Intact THP-1 Cells. Equal volumes of live THP- 1 cells in HBSS and $2 \times$ the test compound in HBSS were mixed, resulting in a final cell concentration of $20 \times 10^{6}$ cells $/ \mathrm{mL}$ and $10 \mu \mathrm{M}$ of the test compound. An incubation with $1 \%$ DMSO only was prepared in parallel as a negative control. Incubations were performed at $37^{\circ} \mathrm{C}$ for $60 \mathrm{~min}$ with continuous mixing. The treated cells were divided into $60 \mu \mathrm{L}$ aliquots and subjected to a 12-step heat challenge between 47 and $67^{\circ} \mathrm{C}$ for $3 \mathrm{~min}$. The heat step was followed by immediate lysis by three rounds of freeze-thawing in liquid nitrogen, followed by centrifugation at $20000 \mathrm{~g}$ for $20 \mathrm{~min}$ to pellet precipitated protein. Then, $40 \mu \mathrm{L}$ of the supernatants was mixed with $20 \mu \mathrm{L}$ of gel loading buffer (NuPAGE LDS sample buffer, Life Technologies), and $10 \mu \mathrm{L}$ of each mixture was loaded per lane on a gel. Protein amounts were detected using western blot techniques, as described above.

Generation of Concentration-Response Curves in THP-1 Cell Lysates. The THP-1 cell lysate was prepared as described for the lysate melt and shift curves above. The lysate was divided into $30 \mu \mathrm{L}$ aliquots, and an equal volume of HEPES buffer containing $2 \times$ the test compound incubation concentration was added. Seven-step dilution concentration-response series of the test compounds in 1\% DMSO were applied, together with $1 \%$ DMSO only as control. The concentration series ranged from $100 \mu \mathrm{M}$ to $10 \mathrm{nM}$. The final cell concentration was $20 \times 10^{6}$ cells $/ \mathrm{mL}$, and compound incubation was performed at $37{ }^{\circ} \mathrm{C}$ for $30 \mathrm{~min}$ with continuous mixing. The treated cells were subjected to a heat challenge at $60{ }^{\circ} \mathrm{C}$ (as determined from the melt curves) for $3 \mathrm{~min}$, followed by separation of the precipitated protein by centrifugation at $20000 \mathrm{~g}$ for $20 \mathrm{~min}$. Then, $40 \mu \mathrm{L}$ of the supernatants (soluble fraction) was mixed with $20 \mu \mathrm{L}$ of gel loading buffer (NuPAGE LDS sample buffer, Life Technologies), and $10 \mu \mathrm{L}$ of each mixture was loaded per lane on a gel. Protein amounts were detected using western blot techniques, as described above.

Generation of Concentration-Response Curves in Intact THP-1 Cells. Live THP- 1 cells in HBSS were divided into $30 \mu \mathrm{L}$ aliquots, and an equal volume of HBSS containing $2 \times$ the test compound incubation concentration was added. Seven-step dilution concentration-response series of the test compounds in $1 \%$ DMSO were applied, together with $1 \%$ DMSO only as control. The concentration series ranged from $100 \mu \mathrm{M}$ to $10 \mathrm{nM}$. The final cell concentration was $20 \times 10^{6}$ cells $/ \mathrm{mL}$, and compound incubation was performed at 37 ${ }^{\circ} \mathrm{C}$ for $60 \mathrm{~min}$ with continuous mixing. The treated cells were subjected to a heat challenge at $56{ }^{\circ} \mathrm{C}$ (as determined from the melt curves) for $3 \mathrm{~min}$, followed by lysis by three rounds of freeze-thawing and separation of precipitated protein by centrifugation at $20000 \mathrm{~g}$ for $20 \mathrm{~min}$. Then, $40 \mu \mathrm{L}$ of the supernatants (soluble fraction) was mixed with $20 \mu \mathrm{L}$ gel loading buffer (NuPAGE LDS sample buffer, Life Technologies), and $10 \mu \mathrm{L}$ of each mixture was loaded per lane on a gel. Protein amounts were detected using western blot techniques, as described above.

Data Analysis. The western blot intensities were obtained by measuring the chemiluminescence counts per square $\mathrm{mm}(I=$ count/ $\mathrm{mm}^{2}$ ). The obtained intensities were plotted as the luminescence count normalized to a relevant temperature or ligand concentration control count as specified. The normalized intensities were plotted using GraphPad Prism analysis software. Data points are shown as mean values with error bars indicating \pm SEM. No error bars are shown if the SEM is smaller than the symbol.

Biophysical Methods. Thermal Shift Assay. Thermal shift assays were performed in a 384-well plate format using a ViiA Real-Time PCR system (Thermo Fisher Scientific). Scans were measured from 25 to $95{ }^{\circ} \mathrm{C}$ at a scanning rate of $4{ }^{\circ} \mathrm{C} / \mathrm{min}$. Melting curves were obtained at a protein concentration of $2.7 \mu \mathrm{M}$ and $6 \times$ SYPRO Orange (Invitrogen) using a buffer containing $20 \mathrm{mM}$ HEPES $\mathrm{pH} 7.5,300$ $\mathrm{mM} \mathrm{NaCl}, 10 \%$ glycerol, and $0.5 \mathrm{mM}$ TCEP. The protein was 
measured in the presence or absence of $100 \mu \mathrm{M}$ of ligand ( $1 \%$ final DMSO concentration). TSA data were analyzed using Genedata Assay Analyzer software.

PIP PIP4K2Aa Protein Production. The expression vector PIP4K2AA-k004 was obtained from the SGC. The sequence comprising PIP4K2A residues (35-405) was integrated behind an $\mathrm{N}$-terminal $6 \times \mathrm{His}$ tag followed by a TEV cleavage site. Protein expression was induced at $17^{\circ} \mathrm{C}$ with $0.5 \mathrm{mM}$ IPTG in BL21(DE3) E. coli cells. The cells were harvested after $18 \mathrm{~h}$ and stored at $-80^{\circ} \mathrm{C}$. Cells were resuspended in buffer A ( $20 \mathrm{mM}$ HEPES, $500 \mathrm{mM} \mathrm{NaCl}$, $10 \%$ glycerol, $0.5 \mathrm{mM}$ TCEP) supplemented with $10 \mathrm{mM}$ imidazole and Roche cOmplete, and disrupted with a microfluidizer $(3 \times, 900$ bar). The protein was purified by affinity chromatography (HisTrap HP $5 \mathrm{~mL}$ column) using buffer A with $10 \mathrm{mM}$ imidazole as a washing buffer and buffer A with $500 \mathrm{mM}$ imidazole as an elution buffer. Eluted fractions were pooled and loaded on a gel filtration column (Superdex 200 26/60; buffer: $20 \mathrm{mM}$ HEPES, $300 \mathrm{mM} \mathrm{NaCl}, 10 \%$ glycerol, $0.5 \mathrm{mM}$ TCEP). Monomeric fractions were pooled and fresh TCEP (final concentration: $2 \mathrm{mM}$ ) was added. Then, the sample was concentrated to $10 \mathrm{mg} / \mathrm{mL}$ and shock-frozen in liquid nitrogen.

X-ray Structures of Compounds 1, 58 (BAY-297), and 60 (BAY-091) in Complex with PIP4K2A. Prior to crystallization, the PIP4K2A protein solution was supplemented with either compound 1, 58 (BAY-297), or 60 (BAY-091) (final concentration: $5 \mathrm{mM}$ ), and the mixture was incubated for $3 \mathrm{~h}$ on ice. The samples were then clarified by centrifugation ( $5 \mathrm{~min}, 13000 \mathrm{~g}, 277 \mathrm{~K}$ ).

Complex crystals were grown using the hanging-drop method by mixing $0.6 \mu \mathrm{L}$ of protein with $1.2 \mu \mathrm{L}$ of reservoir solution $(15-25 \%$ PEG 3350, $200 \mathrm{mM}$ magnesium formate, $25 \%$ glycerol) at $4{ }^{\circ} \mathrm{C}$. Crystals typically grew in 5-7 days. Crystals were flash-frozen in liquid nitrogen. Data were collected under cryogenic conditions on the P11 beamline at the PETRA III, DESY synchrotron facility. The structure was solved by molecular replacement using PDB 2YBX as a search model. The structures were refined using REFMAC5 within the CCP4 suite. ${ }^{39}$ Statistics for the final modes: see the Supporting Information, Table S1.

Pharmacokinetics Assays. Caco-2 Permeability Assay. Caco-2 cells [purchased from the German Collection of Microorganisms and Cell Cultures (DSMZ)] were seeded at a density of $4.5 \times 10^{4}$ cells/ well on 24-well insert plates, $0.4 \mu \mathrm{m}$ pore size, $0.3 \mathrm{~cm}^{2}$ (Costar) and grown for 13-15 days in DMEM medium supplemented with $10 \%$ FCS, 1\% GlutaMAX (100×, Gibco), $100 \mathrm{U} / \mathrm{mL}$ penicillin, $100 \mu \mathrm{g} /$ $\mathrm{mL}$ streptomycin (Gibco), and $1 \%$ nonessential amino acids (100X, Thermo Fischer Scientific). The cells were maintained at $37{ }^{\circ} \mathrm{C}$ in a humidified $5 \% \mathrm{CO}_{2}$ atmosphere. The medium was changed every 23 days.

The bidirectional transport assay for the evaluation of Caco-2 permeability was undertaken in 24-well insert plates using a robotic system (Tecan). Before the assay was run, the culture medium was replaced by a transport medium (FCS-free HEPES carbonate transport buffer $\mathrm{pH}$ 7.2). For the assessment of monolayer integrity, the transepithelial electrical resistance (TEER) was measured. Only monolayers with a TEER of at least $400 \Omega \cdot \mathrm{cm}^{2}$ were used. Test compounds were predissolved in DMSO and added either to the apical or basolateral compartment at a final concentration of $2 \mu \mathrm{M}$. The evaluation was done in triplicate. Before and after incubation at $37^{\circ} \mathrm{C}$ for $2 \mathrm{~h}$, samples were taken from both compartments and, after precipitation with $\mathrm{MeOH}$, analyzed by LC/MS-MS. The apparent permeability coefficient $\left(P_{\text {app }}\right)$ was calculated both for the apical to basolateral $(\mathrm{A} \rightarrow \mathrm{B})$ and the basolateral to apical $(\mathrm{B} \rightarrow \mathrm{A})$ direction using the following equation: $P_{\text {app }}=\left(V_{\mathrm{r}} / P_{0}\right)(1 / S)\left(P_{2} / t\right)$, where $V_{\mathrm{r}}$ is the volume of medium in the receiver chamber, $P_{0}$ is the measured peak area of the test compound in the donor chamber at $t=0, S$ is the surface area of the monolayer, $P_{2}$ is the measured peak area of the test compound in the acceptor chamber after incubation for $2 \mathrm{~h}$, and $t$ is the incubation time. The efflux ratio (ER) basolateral (B) to apical (A) was calculated by dividing $P_{\text {app }} \mathrm{B}-\mathrm{A}$ by $P_{\text {app }} \mathrm{A}-\mathrm{B}$.

PAMPA. In vitro drug permeability was tested using the Corning Gentest Pre-coated PAMPA Plate System, according to the manufacturer's instructions, with a test compound concentration of
$10 \mu \mathrm{M}$. After precipitation with $\mathrm{MeOH}$, samples were quantified by LC-MS/MS analysis.

In Vitro Metabolic Stability in Liver Microsomes. The in vitro metabolic stability of test compounds was determined by incubating them at $1 \mu \mathrm{M}$ in a suspension of liver microsomes in $100 \mathrm{mM}$ phosphate buffer, $\mathrm{pH} 7.4\left(\mathrm{NaH}_{2} \mathrm{PO}_{4} \cdot \mathrm{H}_{2} \mathrm{O}+\mathrm{Na}_{2} \mathrm{HPO}_{4} \cdot 2 \mathrm{H}_{2} \mathrm{O}\right)$ and at a protein concentration of $1 \mathrm{mg} / \mathrm{mL}$ at $37^{\circ} \mathrm{C}$. The microsomes were activated by adding a cofactor mix containing $8 \mathrm{mM}$ glucose-6phosphate, $0.5 \mathrm{mM}$ NADP, and $1 \mathrm{IU} / \mathrm{mL}$ G-6-P-dehydrogenase in phosphate buffer, $\mathrm{pH}$ 7.4. The metabolic assay was started shortly afterward by adding the test compound to the incubation at a final volume of $0.55 \mathrm{~mL}$ (or $1.21 \mathrm{~mL}$ ). The organic solvent in the incubations was limited to $\leq 1 \%$ dimethylsulfoxide (DMSO) and acetonitrile. During incubation, the microsomal suspensions were continuously shaken at $550 \mathrm{rpm}$ (or $375 \mathrm{rpm}$ ) and aliquots were taken at $2,8,16,30,45$, and $60 \mathrm{~min}$, to which double volumes of cold acetonitrile were immediately added. The samples were frozen at $-20^{\circ} \mathrm{C}$ overnight, subsequently centrifuged for $15 \mathrm{~min}$ at $3700 \mathrm{rpm}$, and the supernatant was analyzed with an Agilent 1200 HPLC system with LC-MS/MS detection. The half-life of a test compound was determined from the concentration-time plot. From the half-life, the intrinsic clearances were calculated. Together with the additional parameters, liver blood flow, specific liver weight, and microsomal protein content, the hepatic in vivo blood clearance $(\mathrm{CL})$ and the maximal oral bioavailability $\left(F_{\max }\right)$ were calculated for the different species. The hepatic in vivo blood clearance $\left(\mathrm{CL}_{\text {blood }}\right)$ and the maximal oral bioavailability $\left(F_{\max }\right)$ was calculated using the following formulae: $\mathrm{CL}^{\prime}$ intrinsic $[\mathrm{mL} /(\mathrm{min} \cdot \mathrm{kg})]=\mathrm{kel}[1 / \mathrm{min}] /((\mathrm{mg}$ protein$/$ volume of incubation $[\mathrm{mL}]) \times \mathrm{fu}$,inc $) \times(\mathrm{mg}$ protein/liver weight $[\mathrm{g}]) \times($ specific liver weight $[\mathrm{g}$ liver $/ \mathrm{kg}$ body weight $]) ; \mathrm{CL}_{\text {blood }}$ wellstirred $[\mathrm{L} /(\mathrm{h} \cdot \mathrm{kg})]=\left(\mathrm{QH}[\mathrm{L} /(\mathrm{h} \cdot \mathrm{kg})] \times\right.$ fu,blood $\times \mathrm{CL}^{\prime}$ intrinsic $[\mathrm{L} /$ $(\mathrm{h} \cdot \mathrm{kg})]) /\left(\mathrm{QH}[\mathrm{L} /(\mathrm{h} \cdot \mathrm{kg})]+\right.$ fu,blood $\times \mathrm{CL}^{\prime}$ intrinsic $\left.[\mathrm{L} /(\mathrm{h} \cdot \mathrm{kg})]\right)$; $F_{\max }=1-\mathrm{CL}_{\text {blood }} / \mathrm{QH}$ and using the following parameter values: Liver blood flow--31.32 L/(h.kg) (human), 4.2 L/(h kg) (rat); specific liver weight-21 g/kg (human), $32 \mathrm{~g} / \mathrm{kg}$ (rat); microsomal protein content- $40 \mathrm{mg} / \mathrm{g}$.; and fu,inc and fu,blood is taken as 1 .

In Vitro Metabolic Stability in Rat Hepatocytes. Hepatocytes from Han/Wistar rats were isolated via a two-step perfusion method. After perfusion, the liver was carefully removed from the rat: the liver capsule was opened and the hepatocytes were gently shaken out into a Petri dish with ice-cold Williams' medium E (WME). The resulting cell suspension was filtered through a sterile gauze into $50 \mathrm{~mL}$ Falcon tubes and centrifuged at $50 \mathrm{~g}$ for $3 \mathrm{~min}$ at rt. The cell pellet was resuspended in WME $(30 \mathrm{~mL})$ and centrifuged twice through a Percoll gradient at $100 \mathrm{~g}$. The hepatocytes were washed again with WME and resuspended in a medium containing 5\% FCS. Cell viability was determined by trypan blue exclusion. For the metabolic stability assay, liver cells were distributed in WME containing 5\% FCS into glass vials at a density of $1.0 \times 10^{6}$ vital cells $/ \mathrm{mL}$. The test compound was added to a final concentration of $1 \mu \mathrm{M}$. During incubation, the hepatocyte suspensions were continuously shaken at $580 \mathrm{rpm}$ and aliquots were taken at 2, 8, 16, 30, 45, and $90 \mathrm{~min}$, to which an equal volume of cold $\mathrm{MeOH}$ was immediately added. Samples were frozen at $-20{ }^{\circ} \mathrm{C}$ overnight and subsequently centrifuged for $15 \mathrm{~min}$ at $3000 \mathrm{rpm}$. The supernatant was analyzed with an Agilent 1200 HPLC system with LC-MS/MS detection. The half-life of a test compound was determined from the concentrationtime plot. From the half-life, the intrinsic clearances and the hepatic in vivo blood clearance $(\mathrm{CL})$ and maximal oral bioavailability $\left(F_{\max }\right)$ were calculated using the "well-stirred" liver model ${ }^{40}$ together with the additional parameters liver blood flow, specific liver weight, and the amount of liver cells in vivo and in vitro. The following parameter values were used: liver blood flow-4.2 L/(h kg); specific liver weight $-32 \mathrm{~g} / \mathrm{kg}$ body weight; liver cells in vivo- $1.1 \times 10^{8}$ cells $/ \mathrm{g}$ liver; and liver cells in vitro- $1.0 \times 10^{6} / \mathrm{mL}$.

Inhibition of CYP450 Metabolism. The inhibitory potency of test compounds toward cytochrome P450-dependent metabolic pathways was determined in human liver microsomes by applying individual CYP isoform-selective standard probes (CYP1A2, phenacetin; CYP2C8, amodiaquine; CYP2C9, diclofenac; CYP2D6, dextro- 
methorphan; CYP3A4, midazolam). Reference inhibitors were included as positive controls. Incubation conditions (protein and substrate concentration, incubation time) were optimized with regard to the linearity of metabolite formation. Assays were processed in 96well plates at $37^{\circ} \mathrm{C}$ using a Freedom Evo Workstation (Tecan). After protein precipitation, the metabolite formation was quantified by LCMS/MS analysis followed by inhibition evaluation and $\mathrm{IC}_{50}$ calculation.

Safety Assay. Automated hERG $\mathrm{K}^{+}$Current Voltage-Clamp Assay. The hERG $\mathrm{K}^{+}$current assay is based on a recombinant HEK293 cell line with stable expression of the KCNH2 (HERG) gene. ${ }^{41,42}$ The cells were cultured using a humidified incubator ( 37 ${ }^{\circ} \mathrm{C}, 5 \% \mathrm{CO}_{2}$ ) and a standard culture medium [MEM with Earle's salts and L-glutamine, $10 \%$ noninactivated FCS, $0.1 \mathrm{mM}$ nonessential amino acids, $1 \mathrm{mM}$ sodium pyruvate, penicillin/streptomycin $(50 \mu \mathrm{g} /$ $\mathrm{mL}$ each), $0.4 \mathrm{mg} / \mathrm{mL}$ Geneticin]. Approximately $0.5-8 \mathrm{~h}$ following cell dissociation, the cells were investigated by means of the "wholecell voltage-clamp" technique ${ }^{43}$ in an automated 8-channel system (Patchliner; Nanion Technologies) with PatchControlHT software (Nanion Technologies) to control the Patchliner system and to handle data acquisition and analysis. Voltage-clamp control was provided by two EPC 10 Quadro amplifiers under control of PatchMasterPro software (both HEKA Elektronik) and with NPC-16 medium resistance $(\sim 2 \mathrm{M} \Omega)$ chips (Nanion Technologies) serving as a planar substrate at $\mathrm{rt}\left(22-24{ }^{\circ} \mathrm{C}\right)$. NPC-16 chips were filled with intra- and extracellular solution [intracellular solution: $10 \mathrm{mM} \mathrm{NaCl}$, $50 \mathrm{mM} \mathrm{KCl}, 60 \mathrm{mM} \mathrm{KF}, 20 \mathrm{mM}$ EGTA, $10 \mathrm{mM}$ HEPES pH 7.2 (KOH); extracellular solution: $140 \mathrm{mM} \mathrm{NaCl}, 4 \mathrm{mM} \mathrm{KCl}, 2 \mathrm{mM}$ $\mathrm{CaCl}_{2}, 1 \mathrm{mM} \mathrm{MgCl}$, $5 \mathrm{mM}$ glucose, $10 \mathrm{mM}$ HEPES $\mathrm{pH} 7.4$ $(\mathrm{NaOH})]$ and with the cell suspension. After formation of a $\mathrm{G} \Omega$ seal and entering whole-cell mode (including several automated quality control steps), the cell membrane was clamped to the holding potential $(-80 \mathrm{mV})$. Following an activating clamp step $(+20 \mathrm{mV}$, $1000 \mathrm{~ms}$ ), exclusively hERG-mediated inward tail currents were elicited by hyperpolarizing voltage steps from +20 to $-120 \mathrm{mV}$ (duration $500 \mathrm{~ms}$ ); this clamp protocol was repeated every $12 \mathrm{~s}^{44}$ After an initial stabilization phase (5-6 min), test compounds were added either as a single concentration $(10 \mu \mathrm{M})$ or in ascending concentrations $(0.1,1$, and $10 \mu \mathrm{M} ; 5-6$ min per concentration), followed by several washout steps. Effects of test compounds were quantified by analyzing the amplitude of the hERG-mediated inward tail currents (in \% of predrug control) as a function of test compound concentration (Igor Pro Software). Mean concentration-response data were fitted with a standard sigmoidal four-parameter logistic equation of the form: $Y=$ bottom + (top - bottom $) /(1+$ $10^{\left(\left(\operatorname{LogIC}_{50}-\mathrm{X}\right)\right.} \times$ HillSlope $\left.)\right)$, where $Y$ is the current inhibition (in \% of predrug control), $X$ is the logarithm of drug concentration, and $\mathrm{IC}_{50}$ is the drug concentration producing half-maximal current inhibition, and using the following constraints: top $=100 \%$, bottom $=0 \%$. No curve fitting was performed in cases with an obvious lack of a concentration-dependent current inhibition and/or a too small effect size (ca. $\leq 20 \%)$.

Physicochemical Assays. Stability of Compounds in Solution $\left(\mathrm{pH} \mathrm{10,7}\right.$, and 1 at $\left.37^{\circ} \mathrm{C}\right)$. Solution stability was determined by HPLC-UV. ${ }^{45}$ A $10 \mathrm{mM}$ solution of the test compound in DMSO (5 $\mu \mathrm{L})$ was dissolved in $\mathrm{MeCN}(1 \mathrm{~mL})$. Then, $100 \mu \mathrm{L}$ of this solution was transferred to the respective buffer $(1 \mathrm{~mL})$ and mixed thoroughly. Injections were made immediately after mixing for time zero injection and then again after 1, 2, and $24 \mathrm{~h}$. Compounds were incubated at 37 ${ }^{\circ} \mathrm{C}$. The degradation rate (recovery in \%) was calculated by relating peak areas after 1,2 , and $24 \mathrm{~h}$ to the time zero injection.

Aqueous Solubility of Compound-DMSO Solutions. Aqueous solubility at $\mathrm{pH} 6.5$ was determined by an orientating HTS method. ${ }^{46}$ Test compounds were applied as $1 \mathrm{mM}$ DMSO solutions. After addition of buffer, $\mathrm{pH} 6.5$, solutions were shaken at rt for $24 \mathrm{~h}$. Undissolved material was removed by filtration. The compound dissolved in the supernatant was quantified by HPLC-MS/MS.

$\log D$ Measurement. $\log D$ values at $\mathrm{pH} 7.5$ were recorded using an indirect method for determining hydrophobicity constants by reversed-phase HPLC. ${ }^{47}$ A homologous series of $n$-alkan-2-ones $\left(\mathrm{C}_{3}-\right.$
$\mathrm{C}_{16}, 0.02 \mathrm{M}$ in $\mathrm{MeCN}$ ) was used for calibration. Test compounds were applied as $0.67 \mathrm{mM}$ DMSO stock solutions in $\mathrm{MeCN} / \mathrm{H}_{2} \mathrm{O}$ $(1: 1)$. The lipophilicity of compounds was then assessed by comparison to the calibration curve.

\section{ASSOCIATED CONTENT}

\section{Supporting Information}

The Supporting Information is available free of charge at https://pubs.acs.org/doi/10.1021/acs.jmedchem.1c01245.

Comparison of PIP4K2A with PIP4K2B and PIP4K2C isoforms; crystallographic data for 1, 58 (BAY-297), and 60 (BAY-091); electron density of 1; total and phospho levels of AKT and PP2A in THP-1 cells; and kinase selectivity panel data for 58 (BAY-297) and 60 (BAY091) (PDF)

Molecular formula strings (CSV)

\section{Accession Codes}

The coordinates and structure factors for the described crystal structures have been deposited with the Protein Data Bank (PDB) under the following PDB accession codes: compounds 1 (PDB 6YM3), 58 (BAY-297) (PDB 6YM4), and 60 (BAY091) (PDB 6YM5). The authors will release the atomic coordinates upon article publication.

\section{AUTHOR INFORMATION}

\section{Corresponding Author}

Clara Lemos - Bayer AG, Research \& Development, Pharmaceuticals, 13353 Berlin, Germany;

Email: Clara.Lemos@bayer.com

\section{Authors}

Lars Wortmann - Bayer AG, Research \& Development, Pharmaceuticals, 13353 Berlin, Germany; Present Address: Medicinal Chemistry, Boehringer Ingelheim Pharma GmbH \& Co. KG, 88397 Biberach an der Riß, Germany; orcid.org/0000-0001-6514-947X

Nico Bräuer - Bayer AG, Research \& Development, Pharmaceuticals, 13353 Berlin, Germany; Present Address: Nuvisan ICB GmbH, 13353 Berlin, Germany.; (1) orcid.org/0000-0003-2583-6018

Simon J. Holton - Bayer AG, Research \& Development, Pharmaceuticals, 13353 Berlin, Germany; Present Address: Nuvisan ICB GmbH, 13353 Berlin, Germany.

Horst Irlbacher - Bayer AG, Research \& Development, Pharmaceuticals, 13353 Berlin, Germany; Present Address: Nuvisan ICB GmbH, 13353 Berlin, Germany.

Jörg Weiske - Bayer AG, Research \& Development, Pharmaceuticals, 13353 Berlin, Germany; Present Address: Nuvisan ICB GmbH, 13353 Berlin, Germany.

Christian Lechner - Bayer AG, Research \& Development, Pharmaceuticals, 13353 Berlin, Germany; Present Address: Nuvisan ICB GmbH, 13353 Berlin, Germany.

Robin Meier - Bayer AG, Research \& Development, Pharmaceuticals, 13353 Berlin, Germany; Present Address: Medicinal Chemistry, Boehringer Ingelheim Pharma GmbH \& Co. KG, 88397 Biberach an der Riß, Germany.

Jakob Karén - Pelago Bioscience AB, 17148 Solna, Sweden

Catrine Berthold Siöberg - Pelago Bioscience AB, 17148 Solna, Sweden

Vera Pütter - Bayer AG, Research \& Development, Pharmaceuticals, 13353 Berlin, Germany; Present Address: Nuvisan ICB GmbH, 13353 Berlin. 
Clara D. Christ - Bayer AG, Research \& Development, Pharmaceuticals, 13353 Berlin, Germany; (i) orcid.org/ 0000-0002-5424-9819

Antonius ter Laak - Bayer AG, Research \& Development, Pharmaceuticals, 13353 Berlin, Germany

Philip Lienau - Bayer AG, Research \& Development, Pharmaceuticals, 13353 Berlin, Germany

Ralf Lesche - Bayer AG, Research \& Development, Pharmaceuticals, 13353 Berlin, Germany; Present Address: Nuvisan ICB GmbH, 13353 Berlin, Germany.

Barbara Nicke - Bayer AG, Research \& Development, Pharmaceuticals, 13353 Berlin, Germany; Present Address: Nuvisan ICB GmbH, 13353 Berlin, Germany.

Shing-Hu Cheung - Bayer AG, Research \& Development, Pharmaceuticals, 13353 Berlin, Germany

Marcus Bauser - Bayer AG, Research \& Development, Pharmaceuticals, 13353 Berlin, Germany; Present Address: Janssen Pharmaceuticals, Discovery Sciences, 2340 Beerse, Belgium.

Andrea Haegebarth - Bayer AG, Research \& Development, Pharmaceuticals, 13353 Berlin, Germany

Franz von Nussbaum - Bayer AG, Research \& Development, Pharmaceuticals, 13353 Berlin, Germany; Present

Address: Nuvisan ICB GmbH, 13353 Berlin, Germany

Dominik Mumberg - Bayer AG, Research \& Development, Pharmaceuticals, 13353 Berlin, Germany

Complete contact information is available at:

https://pubs.acs.org/10.1021/acs.jmedchem.1c01245

\section{Author Contributions}

This manuscript was written with contributions from all authors. All authors have given approval to the final version of the manuscript.

\section{Notes}

The authors declare the following competing financial interest(s): L.W., N.B., S.J.H., H.I., J.W., C.L., R.M., V.P., C.C., A.t.L., P.L., R.L., B.N., S.-H.C., M.B., A.H., F.v.N., D.M., and C.L. are or have been employees of Bayer AG and may have additional stock options. J.K. and C.B.S. are or have been employees of Pelago Bioscience AB.

\section{ACKNOWLEDGMENTS}

The authors thank Kay Greenfield for critically proofreading the manuscript, Ewa Chudyk (Evotec) for computational chemistry support, and Elke Ducke, Bodo Röhr, Robert Sell, Carsten Schreier, Marcello Spinczyk (Medicinal Chemistry), Enrico Spelling, Maria Hallmann, Katja Köckritz, Jana Hannig, Sven Christian, Valeria Santoro (Pharmacology), and Ivonne Herms (Structural Biology) for excellent technical support throughout the whole project.

\section{ABBREVIATIONS USED}

AKT, $\alpha$ serine/threonine-protein kinase; CETSA, cellular thermal shift assay; FACS, fluorescence-activated cell sorting; HTRF, homogeneous time-resolved fluorescence; mTOR, mechanistic target of rapamycin; PAMPA, parallel artificial membrane permeability assay; $\mathrm{PI} 4,5 \mathrm{P}_{2}$, phosphatidylinositol 4,5-bisphosphate; PI5P, phosphatidylinositol-5-phosphate; PIP4K2A, phosphatidylinositol-5-phosphate 4-kinase type II $\alpha$; PROTAC, proteolysis targeting chimera; PTEN, phosphatase and tensin homolog; ROS, reactive oxygen species;
RMSD, root mean square deviation; TPSA, topological polar surface area; TSA, thermal shift assay

\section{REFERENCES}

(1) Fiume, R.; Stijf-Bultsma, Y.; Shah, Z. H.; Keune, W. J.; Jones, D. R.; Jude, J. G.; Divecha, N. PIP4K and the role of nuclear phosphoinositides in tumour suppression. Biochim. Biophys. Acta, Mol. Cell Biol. Lipids 2015, 1851, 898-910.

(2) Emerling, B. M.; Hurov, J. B.; Poulogiannis, G.; Tsukazawa, K.; Choo-Wing, R.; Wulf, G. M.; Bell, E. L.; Shim, H.-S.; Lamia, K. A.; Rameh, L. E.; Bellinger, G.; Sasaki, A. T.; Asara, J. M.; Yuan, X.; Bullock, A.; DeNicola, G. M.; Song, J.; Brown, V.; Signoretti, S.; Cantley, L. C. Depletion of a putatively druggable class of phosphatidylinositol kinases inhibits growth of p53-null tumors. Cell 2013, 155, 844-857.

(3) Jones, D. R.; Foulger, R.; Keune, W.-J.; Bultsma, Y.; Divecha, N. PtdIns5P is an oxidative stress-induced second messenger that regulates PKB activation. FASEB J. 2013, 27, 1644-1656.

(4) Jude, J. G.; Spencer, G. J.; Huang, X.; Somerville, T. D. D.; Jones, D. R.; Divecha, N.; Somervaille, T. C. P. A targeted knockdown screen of genes coding for phosphoinositide modulators identifies PIP4K2A as required for acute myeloid leukemia cell proliferation and survival. Oncogene 2015, 34, 1253-1262.

(5) Carricaburu, V.; Lamia, K. A.; Lo, E.; Favereaux, L.; Payrastre, B.; Cantley, L. C.; Rameh, L. E. The phosphatidylinositol (PI)-5phosphate 4-kinase type II enzyme controls insulin signaling by regulating PI-3,4,5-trisphosphate degradation. Proc. Natl. Acad. Sci. U.S.A. 2003, 100, 9867-9872.

(6) Ramel, D.; Lagarrigue, F.; Dupuis-Coronas, S.; Chicanne, G.; Leslie, N.; Gaits-Iacovoni, F.; Payrastre, B.; Tronchère, H. PtdIns5P protects Akt from dephosphorylation through PP2A inhibition. Biochem. Biophys. Res. Commun. 2009, 387, 127-131.

(7) Nogueira, V.; Park, Y.; Chen, C.-C.; Xu, P.-Z.; Chen, M.-L.; Tonic, I.; Unterman, T.; Hay, N. Akt determines replicative senescence and oxidative or oncogenic premature senescence and sensitizes cells to oxidative apoptosis. Cancer Cell 2008, 14, 458-470.

(8) Dolado, I.; Nebreda, A. R. AKT and oxidative stress team up to kill cancer cells. Cancer Cell 2008, 14, 427-429.

(9) Gurpinar, E.; Vousden, K. H. Hitting cancers' weak spots: vulnerabilities imposed by p53 mutation. Trends Cell Biol. 2015, 25, 486-495.

(10) Sivakumaren, S. C.; Shim, H.; Zhang, T.; Ferguson, F. M.; Lundquist, M. R.; Browne, C. M.; Seo, H.-S.; Paddock, M. N.; Manz, T. D.; Jiang, B.; Hao, M.-F.; Krishnan, P.; Wang, D. G.; Yang, T. J.; Kwiatkowski, N. P.; Ficarro, S. B.; Cunningham, J. M.; Marto, J. A.; Dhe-Paganon, S.; Cantley, L. C.; Gray, N. S. Targeting the PI5P4K lipid kinase family in cancer using covalent inhibitors. Cell Chem. Biol. 2020, 27, 525-537.e6.

(11) Lamia, K. A.; Peroni, O. D.; Kim, Y.-B.; Rameh, L. E.; Kahn, B. B.; Cantley, L. C. Increased insulin sensitivity and reduced adiposity in phosphatidylinositol 5-phosphate 4-kinase $\beta^{-/-}$mice. Mol. Cell. Biol. 2004, 24, 5080-5087.

(12) Mathis, G. HTRF technology. J. Biomol. Screening 1999, 4, 309-313.

(13) Degorce, F. HTRF: pioneering technology for high-throughput screening. Expert Opin. Drug Discovery 2006, 1, 753-764.

(14) Degorce, F.; Card, A.; Soh, S.; Trinquet, E.; Knapik, G. P.; Xie, B. HTRF: a technology tailored for drug discovery -a review of theoretical aspects and recent applications. Curr. Chem. Genomics 2009, 3, 22-32.

(15) Baell, J. B.; Holloway, G. A. New substructure filters for removal of pan assay interference compounds (PAINS) from screening libraries and for their exclusion in bioassays. J. Med. Chem. 2010, 53, 2719-2740.

(16) Grøftehauge, M. K.; Hajizadeh, N. R.; Swann, M. J.; Pohl, E. Protein-ligand interactions investigated by thermal shift assays (TSA) and dual polarization interferometry (DPI). Acta Crystallogr., Sect. D: Biol. Crystallogr. 2015, 71, 36-44. 
(17) Lipinski, C. A.; Lombardo, F.; Dominy, B. W.; Feeney, P. J. Experimental and computational approaches to estimate solubility and permeability in drug discovery and development settings. Adv. Drug Delivery Rev. 2001, 46, 3-26.

(18) Veber, D. F.; Johnson, S. R.; Cheng, H.-Y.; Smith, B. R.; Ward, K. W.; Kopple, K. D. Molecular properties that influence the oral bioavailability of drug candidates. J. Med. Chem. 2002, 45, 26152623.

(19) Shinada, N. K.; de Brevern, A. G.; Schmidtke, P. Halogens in protein-ligand binding mechanism: a structural perspective. J. Med. Chem. 2019, 62, 9341-9356.

(20) Molina, D. M.; Jafari, R.; Ignatushchenko, M.; Seki, T.; Larsson, E. A.; Dan, C.; Sreekumar, L.; Cao, Y.; Nordlund, P. Monitoring drug target engagement in cells and tissues using the cellular thermal shift assay. Science 2013, 341, 84-87.

(21) Davies, B. R.; Greenwood, H.; Dudley, P.; Crafter, C.; Yu, D.H.; Zhang, J.; Li, J.; Gao, B.; Ji, Q.; Maynard, J.; Ricketts, S.-A.; Cross, D.; Cosulich, S.; Chresta, C. C.; Page, K.; Yates, J.; Lane, C.; Watson, R.; Luke, R.; Ogilvie, D.; Pass, M. Preclinical pharmacology of AZD5363, an inhibitor of AKT: pharmacodynamics, antitumor activity, and correlation of monotherapy activity with genetic background. Mol. Cancer Ther. 2012, 11, 873-887.

(22) Kitagawa, M.; Liao, P.-J.; Lee, K. H.; Wong, J.; Shang, S. C.; Minami, N.; Sampetrean, O.; Saya, H.; Lingyun, D.; Prabhu, N.; Diam, G. K.; Sobota, R.; Larsson, A.; Nordlund, P.; McCormick, F.; Ghosh, S.; Epstein, D. M.; Dymock, B. W.; Lee, S. H. Dual blockade of the lipid kinase PIP4Ks and mitotic pathways leads to cancerselective lethality. Nat. Commun. 2017, 8, No. 2200.

(23) Shin, Y. J.; Sa, J. K.; Lee, Y.; Kim, D.; Chang, N.; Cho, H. J.; Son, M.; Oh, M. Y. T.; Shin, K.; Lee, J.-K.; Park, J.; Jo, Y. K.; Kim, M.; Paddison, P. J.; Tergaonkar, V.; Lee, J.; Nam, D.-H. PIP4K2A as a negative regulator of PI3K in PTEN-deficient glioblastoma. J. Exp. Med. 2019, 216, 1120-1134.

(24) Arrowsmith, C. H.; Audia, J. E.; Austin, C.; Baell, J.; Bennett, J.; Blagg, J.; Bountra, C.; Brennan, P. E.; Brown, P. J.; Bunnage, M. E.; Buser-Doepner, C.; Campbell, R. M.; Carter, A. J.; Cohen, P.; Copeland, R. A.; Cravatt, B.; Dahlin, J. L.; Dhanak, D.; Edwards, A. M.; Frederiksen, M.; Frye, S. V.; Gray, N.; Grimshaw, C. E.; Hepworth, D.; Howe, T.; Huber, K. V. M.; Jin, J.; Knapp, S.; Kotz, J. D.; Kruger, R. G.; Lowe, D.; Mader, M. M.; Marsden, B.; MuellerFahrnow, A.; Müller, S.; O'Hagan, R. C.; Overington, J. P.; Owen, D. R.; Rosenberg, S. H.; Ross, R.; Roth, B.; Schapira, M.; Schreiber, S. L.; Shoichet, B.; Sundström, M.; Superti-Furga, G.; Taunton, J.; ToledoSherman, L.; Walpole, C.; Walters, M. A.; Willson, T. M.; Workman, P.; Young, R. N.; Zuercher, W. J. The promise and peril of chemical probes. Nat. Chem. Biol. 2015, 11, 536-541.

(25) Müller, S.; Ackloo, S.; Arrowsmith, C. H.; Bauser, M.; Baryza, J. L.; Blagg, J.; Böttcher, J.; Bountra, C.; Brown, P. J.; Bunnage, M. E.; Carter, A. J.; Damerell, D.; Dötsch, V.; Drewry, D. H.; Edwards, A. M.; Edwards, J.; Elkins, J. M.; Fischer, C.; Frye, S. V.; Gollner, A.; Grimshaw, C. E.; IJzerman, A.; Hanke, T.; Hartung, I. V.; Hitchcock, S.; Howe, T.; Hughes, T. V.; Laufer, S.; Li, V. M. J.; Liras, S.; Marsden, B. D.; Matsui, H.; Mathias, J.; O'Hagan, R. C.; Owen, D. R.; Pande, V.; Rauh, D.; Rosenberg, S. H.; Roth, B. L.; Schneider, N. S.; Scholten, C.; Singh Saikatendu, K.; Simeonov, A.; Takizawa, M.; Tse, C.; Thompson, P. R.; Treiber, D. K.; Viana, A. Y. I.; Wells, C. I.; Willson, T. M.; Zuercher, W. J.; Knapp, S.; Mueller-Fahrnow, A. Donated chemical probes for open science. eLife 2018, 7, No. e34311.

(26) Structural Genomics Consortium (SCG). https://www.thesgc. org (accessed April 7, 2020).

(27) TBK/IKKE (BAY-985): Lefranc, J.; Schulze, V. K.; Hillig, R. C.; Briem, H.; Prinz, F.; Mengel, A.; Heinrich, T.; Balint, J.; Rengachari, S.; Irlbacher, H.; Stöckigt, D.; Bömer, U.; Bader, B.; Gradl, S. N.; Nising, C. F.; von Nussbaum, F.; Mumberg, D.; Panne, D.; Wengner, A. M. Discovery of BAY-985, a highly selective TBK1/IKK $\varepsilon$ inhibitor. J. Med. Chem. 2020, 63, 601-612.

(28) Werner, S.; Mesch, S.; Hillig, R. C.; ter Laak, A.; Klint, J.; Neagoe, I.; Laux-Biehlmann, A.; Dahllöf, H.; Bräuer, N.; Puetter, V.; Nubbemeyer, R.; Schulz, S.; Bairlein, M.; Zollner, T. M.; Steinmeyer,
A. Discovery and characterization of the potent and selective P2X4 inhibitor $N$-[4-(3-chlorophenoxy)-3-sulfamoylphenyl]-2-phenylacetamide (BAY-1797) and structure-guided amelioration of its CYP3A4 induction profile. J. Med. Chem. 2019, 62, 11194-11217. P2X4 (BAY-1797):

(29) Wortmann, L.; Lindenthal, B.; Muhn, P.; Walter, A.; Nubbemeyer, A.; Heldmann, D.; Sobek, L.; Morandi, F.; Schrey, A. K.; Moosmayer, D.; Günther, J.; Kuhnke, J.; Koppitz, M.; Lücking, U.; Röhn, U.; Schäfer, M.; Nowak-Reppel, K.; Kühne, R.; Weinmann, H.; Langer, G. Discovery of BAY-298 and BAY-899: tetrahydro-1,6naphthyridine-based, potent, and selective antagonists of the luteinizing hormone receptor which reduce sex hormone levels in vivo. J. Med. Chem. 2019, 62, 10321-10341. Luteinizing hormone receptor antagonist (BAY-899):

(30) Hillig, R. C.; Sautier, B.; Schroeder, J.; Moosmayer, D.; Hilpmann, A.; Stegmann, C. M.; Werbeck, N. D.; Briem, H.; Boemer, U.; Weiske, J.; Badock, V.; Mastouri, J.; Petersen, K.; Siemeister, G.; Kahmann, J. D.; Wegener, D.; Böhnke, N.; Eis, K.; Graham, K.; Wortmann, L.; von Nussbaum, F.; Bader, B. Discovery of potent SOS1 inhibitors that block RAS activation via disruption of the RASSOS1 interaction. Proc. Natl. Acad. Sci. U.S.A. 2019, 116, 2551-2560. KRAS-SOS1 (BAY-293):

(31) Nguyen, D.; Lemos, C.; Wortmann, L.; Eis, K.; Holton, S. J.; Boemer, U.; Moosmayer, D.; Eberspaecher, U.; Weiske, J.; Lechner, C.; Prechtl, S.; Suelzle, D.; Siegel, F.; Prinz, F.; Lesche, R.; Nicke, B.; Nowak-Reppel, K.; Himmel, H.; Mumberg, D.; von Nussbaum, F.; Nising, C. F.; Bauser, M.; Haegebarth, A. Discovery and characterization of the potent and highly selective (piperidin-4-yl)pyrido[3,2d]pyrimidine based in vitro probe BAY-885 for the kinase ERK5. J. Med. Chem. 2019, 62, 928-940. ERK5 (BAY-885):

(32) Rahm, F.; Viklund, J.; Trésaugues, L.; Ellermann, M.; Giese, A.; Ericsson, U.; Forsblom, R.; Ginman, T.; Günther, J.; Hallberg, K.; Lindström, J.; Persson, L. B.; Silvander, C.; Talagas, A.; Díaz-Sáez, L.; Fedorov, O.; Huber, K. V. M.; Panagakou, I.; Siejka, P.; Gorjánácz, M.; Bauser, M.; Andersson, M. Creation of a novel class of potent and selective MutT homologue 1 (MTH1) inhibitors using fragmentbased screening and structure-based drug design. J. Med. Chem. 2018, 61, 2533-2551. MTH1 (BAY-707):

(33) Schneider, H.; Szabo, E.; Machado, R. A. C.; Broggini-Tenzer, A.; Walter, A.; Lobell, M.; Heldmann, D.; Süssmeier, F.; Grünewald, S.; Weller, M. Novel TIE-2 inhibitor BAY-826 displays in vivo efficacy in experimental syngeneic murine glioma models. J. Neurochem. 2017, 140, 170-182. TIE2 (BAY-826):

(34) Bouché, L.; Christ, C. D.; Siegel, S.; Fernández-Montalván, A. E.; Holton, S. J.; Fedorov, O.; ter Laak, A.; Sugawara, T.; Stöckigt, D.; Tallant, C.; Bennett, J.; Monteiro, O.; Díaz-Sáez, L.; Siejka, P.; Meier, J.; Pütter, V.; Weiske, J.; Müller, S.; Huber, K. V. M.; Hartung, I. V.; Haendler, B. Benzoisoquinolinediones as potent and selective inhibitors of BRPF2 and TAF1/TAF1L bromodomains. J. Med. Chem. 2017, 60, 4002-4022. BRD1/TAF1 (BAY-299):

(35) Fernández-Montalván, A. E.; Berger, M.; Kuropka, B.; Koo, S. J.; Badock, V.; Weiske, J.; Puetter, V.; Holton, S. J.; Stöckigt, D.; ter Laak, A.; Centrella, P. A.; Clark, M. A.; Dumelin, C. E.; Sigel, E. A.; Soutter, H. H.; Troast, D. M.; Zhang, Y.; Cuozzo, J. W.; Keefe, A. D.; Roche, D.; Rodeschini, V.; Chaikuad, A.; Díaz-Sáez, L.; Bennett, J. M.; Fedorov, O.; Huber, K. V. M.; Hübner, J.; Weinmann, H.; Hartung, I. V.; Gorjánácz, M. Isoform-selective ATAD2 chemical probe with novel chemical structure and unusual mode of action. ACS Chem. Biol. 2017, 12, 2730-2736. ATAD2 (BAY-850):

(36) Eggert, E.; Hillig, R. C.; Koehr, S.; Stöckigt, D.; Weiske, J.; Barak, N.; Mowat, J.; Brumby, T.; Christ, C. D.; ter Laak, A.; Lang, T.; Fernandez-Montalvan, A. E.; Badock, V.; Weinmann, H.; Hartung, I. V.; Barsyte-Lovejoy, D.; Szewczyk, M.; Kennedy, S.; Li, F.; Vedadi, M.; Brown, P. J.; Santhakumar, V.; Arrowsmith, C. H.; Stellfeld, T.; Stresemann, C. Discovery and characterization of a highly potent and selective aminopyrazoline-based in vivo probe (BAY-598) for the protein lysine methyltransferase SMYD2. J. Med. Chem. 2016, 59, 4578-4600. SMYD2 (BAY-598): 
(37) von Nussbaum, F.; Li, V. M.; Meibom, D.; Anlauf, S.; Bechem, M.; Delbeck, M.; Gerisch, M.; Harrenga, A.; Karthaus, D.; Lang, D.; Lustig, K.; Mittendorf, J.; Schäfer, M.; Schäfer, S.; Schamberger, J. Potent and selective human neutrophil elastase inhibitors with novel equatorial ring topology: in vivo efficacy of the polar pyrimidopyridazine BAY-8040 in a pulmonary arterial hypertension rat model. ChemMedChem 2016, 11, 199-206. Neutrophil Elastase (BAY-678): (38) Siebeneicher, H.; Cleve, A.; Rehwinkel, H.; Neuhaus, R.; Heisler, I.; Müller, T.; Bauser, M.; Buchmann, B. Identification and optimization of the first highly selective GLUT1 inhibitor BAY-876. ChemMedChem 2016, 11, 2261-2271. GLUT1 (BAY-876):

(39) Winn, M. D.; Ballard, C. C.; Cowtan, K. D.; Dodson, E. J.; Emsley, P.; Evans, P. R.; Keegan, R. M.; Krissinel, E. B.; Leslie, A. G. W.; McCoy, A.; McNicholas, S. J.; Murshudov, G. N.; Pannu, N. S.; Potterton, E. A.; Powell, H. R.; Read, R. J.; Vagin, A.; Wilson, K. S. Overview of the CCP4 suite and current developments. Acta Crystallogr., Sect. D: Biol. Crystallogr. 2011, 67, 235-242.

(40) Pang, K. S.; Rowland, M. Hepatic clearance of drugs. I. Theoretical considerations of a "well-stirred" model and a "parallel tube" model. Influence of hepatic blood flow, plasma and blood cell binding, and the hepatocellular enzymatic activity on hepatic drug clearance. J. Pharmacokinet. Biopharm. 1977, 5, 625-653.

(41) Zhou, Z.; Gong, Q.; Ye, B.; Fan, Z.; Makielski, J. C.; Robertson, G. A.; January, C. T. Properties of HERG channels stably expressed in HEK 293 cells studied at physiological temperature. Biophys. J. 1998, 74, 230-241.

(42) Sanguinetti, M. C.; Chandy, K. G.; Grissmer, S.; Gutman, G. A.; Lazdunski, M.; Mckinnon, D.; Pardo, L. A.; Robertson, G. A.; Rudy, B.; Stuehmer, W.; Wang, X. L. Voltage-gated potassium channels: Kv11.1 (hERG). IUPHAR/BPS Guide to Pharmacology. http:// www.guidetopharmacology.org (accessed Nov 15, 2018).

(43) Hamill, O. P.; Marty, A.; Neher, E.; Sakmann, B.; Sigworth, F. J. Improved patch-clamp techniques for high-resolution current recording from cells and cell-free membrane patches. Pfluegers Arch. 1981, $391,85-100$.

(44) Himmel, H. M. Suitability of commonly used excipients for electrophysiological in-vitro safety pharmacology assessment of effects on hERG potassium current and on rabbit Purkinje fiber action potential. J. Pharmacol. Toxicol. Methods 2007, 56, 145-158.

(45) Kerns, E. H.; Di, L. Drug-like Properties: Concepts, Structure Design and Methods; Academic Press: Burlington, MA, 2008; pp 353356.

(46) Onofrey, T.; Kazan, G. Performance and Correlation of a 96-Well High Throughput Screening Method to Determine Aqueous Drug Solubility, Application Note Lit. No. AN1731EN00; Millipore Corporation: Billerica, MA, USA, 2003.

(47) Minick, D. J.; Frenz, J. H.; Patrick, M. A.; Brent, D. A. A comprehensive method for determining hydrophobicity constants by reversed-phase high-performance liquid chromatography. J. Med. Chem. 1988, 31, 1923-1933. 